\title{
HUNGARIAN ASSYRIOLOGICAL HAR REVIEW
}

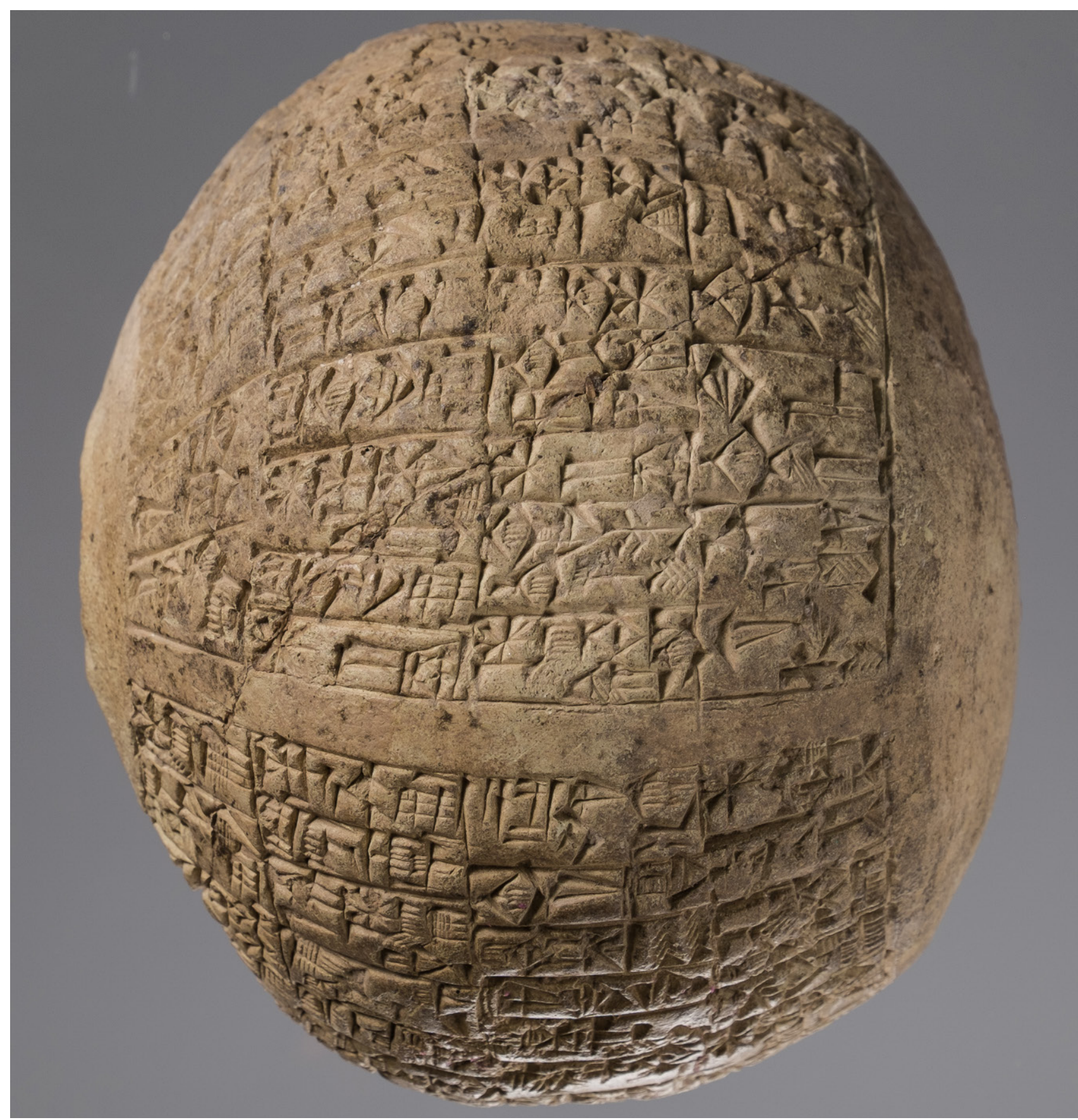

VOLUME 1 | ISSUE 1 | 2020 
ON THE COVER:

Jar-like clay object (T.3860),

Sulaymaniyah Museum. See pp. 21-39.

Photo: Suleymaniah Museum 


\section{HUNGARIAN ASSYRIOLOGICAL REVIEW

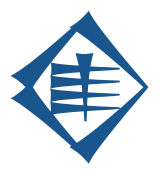 \\ VOLUME 1, ISSUE 1 \\ 2020}

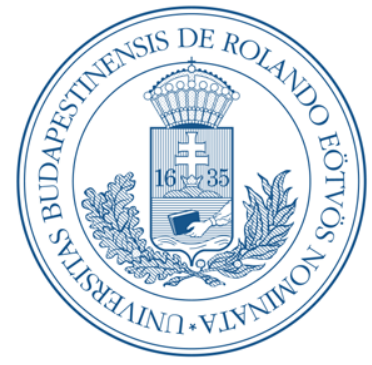

Institute of Archaeological Sciences

Institute of Ancient and Classical Studies

Eötvös Loránd University

Budapest 


\section{HUNGARIAN}

\section{HAR - Hungarian Assyriological Review}

Journal of the Institute of Archaeological Sciences and the Institute of Ancient and Classical Studies (Department of Assyriology and Hebrew Studies), Eötvös Loránd University, Budapest, Hungary.

HAR is a peer-reviewed electronic journal (HU ISSN 2732-2610) published in two issues per year. The journal covers the philology and the archaeology of the Ancient Near East, publishing research articles, brief notes, and field reports.

Papers in HAR are published under the platinum open access model, which means permanent and free access in downloadable format (pdf) for readers and no publication fees for authors. The issues can be both downloaded for free and ordered as printed volumes at own cost.

For article submission guidelines, see https://harjournal.com/author-guidelines/

\section{Editorial board}

Editor-in-chief (szerkesztésért felelös személy):

Gábor Kalla, Eötvös Loránd University, Budapest

\section{Associate editors:}

Zsombor J. Földi, Ludwig-Maximilians-Universität, München

Zsolt Simon, Ludwig-Maximilians-Universität, München

\section{Editorial board:}

Tamás Dezső, Eötvös Loránd University, Budapest

Gábor Zólyomi, Eötvös Loránd University, Budapest

Technical editor:

Attila Király

Publisher (kiadó és kiadásért felelös személy):

Gábor Kalla, Eötvös Loránd University, Budapest

\section{Registered office (a kiadó székhelye):}

Institute of Archaeological Sciences, Múzeum Krt. 4/B., 1088 Budapest, Hungary.

Email address: info@harjournal.com

\section{Design and typesetting:}

Attila Király (attila@litikum.hu)

using Noto font family by Google Inc., under the terms of the SIL Open Font License. 


\section{CONTENTS}

\section{Hungarian Assyriological Review}

\section{volume 1, issue 1, 2020}

Editorial

Zsombor J. Földi, Gábor Kalla, Zsolt Simon

Paratactic relative clauses in Sumerian

Gábor Zólyomi

An abbreviated version of En-metena 1 from the Sulaymaniyah Museum

Ardalan Khwshnaw - Gábor Zólyomi

Cuneiform Luwian =ku(wa): form and meaning

Zsolt Simon

The property of the city, the property of the king? A new fragment of YOS 12, 321

zsombor J. Földi

Intercalary Months and Interest-bearing Loans in Babylonia.

A Promissory Note from the Egibi Archive

Zoltán Csabai

Hungarian Assyriological Review

Author Guidelines 



\title{
Editorial
}

\section{Hungarian Assyriological Review - a new journal}

\author{
Zsombor J. Földi, Gábor Kalla, Zsolt Simon
}

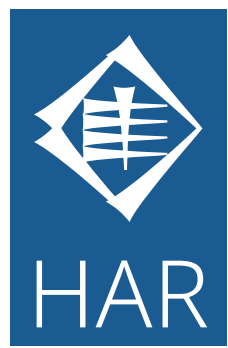

Tradition and modernity. This is the motto with which the Editorial Board welcomes the readers of the newly-founded Hungarian Assyriological Review (HAR). Although there is no shortage of well-established journals with high academic standards for Ancient Near Eastern studies (usually hidden behind pay-walls), the number of journals that make use of the potentials of the online world remains modest and these publications tend to focus on short contributions. Thus, HAR aims to combine the benefits of both worlds by simultaneously providing high quality in scholarly content and exploiting the advantages of online publishing. This combination should result in quick publication, a modern layout, and unlimited and free access to all interested readers alongside a printed version for those who prefer a more traditional way of reading and archiving. The motto "tradition and modernity" applies to the content as well: "Assyriology" is meant in its broadest sense and the scope of the journal includes not only Mesopotamia and the cuneiform culture(s), but the entire Ancient Near East. Accordingly, the journal welcomes both philologically and archaeologically oriented contributions. Despite the recent trend of scholarly monolingualism in publishing, HAR accepts papers written both in English and German.

Tradition and modernity underlie not only the "Assyriological", but also the "Hungarian" side of this journal. Research on the Ancient Near East in Hungary started at the beginning of the 20th century, and covered not only Mesopotamia, but also other regions such as Anatolia from the very beginning. However, the creation of the institutional framework took a disappointingly long time. Following an early, short-lived attempt (1910-1928), it was as late as 1980 when a departmental research group of Assyriology was established at the Eötvös Loránd University in Budapest. This led to the foundation of the Department of Assyriology and Hebrew Studies in 1989 and, over a decade later, to the introduction of a curriculum of Ancient Near Eastern archaeology in the Institute of Archaeological Sciences of the same university. Finally, the first Hungarian excavation to investigate an Ancient Near Eastern site was begun in 2016 at Grd-i Tle in Iraqi Kurdistan, whose excavation reports will be featured in HAR. The publication of a journal devoted solely to Assyriology fulfils yet another old ambition of Hungarian scholars.

These, then, are the traditions from which this journal draws and the editors sincerely hope that it will contribute to research on the Ancient Near East as well as to its development in Hungary.

The Editors:

Zsombor J. Földi (LMU München)

Gábor Kalla (ELTE Budapest)

Zsolt Simon (LMU München) 



\title{
Paratactic relative clauses in Sumerian
}

\section{Gábor Zólyomi*}

* - Department of Assyriology and Hebrew Studies, Eötvös L. University, Budapest. Email: zolyomi.gabor@ btk.elte.hu

\begin{abstract}
Using the interpretation and analysis of the passage Ur-Namma 28 1:10-13 as starting point, this paper argues that copular clauses in Sumerian may function as paratactic relative clauses in biclausal constructions. It also demonstrates that the choice that which participant of the copular clause will function as head is determined not by the syntactic but by the pragmatic function of the participants. In the concluding part, the paper contends that the grammatical construction used in the frequently discussed passage E-ana-tum 5 5:10-17 is the same as that of Ur-Namma 28 1:10-13. It shows that the oddity of the E-ana-tum passage is due to the phenomenon that the name E-ana-tum is used once as an expression referring to a person, the ruler of Lagaš, and once as an expression referring to his name.
\end{abstract}

Keywords: Sumerian grammar, copular clauses, left-dislocation, paratactic relative clauses, royal inscriptions

Cite as Zólyomi, G. 2020: Paratactic relative clauses in Sumerian. Hungarian Assyriological Review 1, 9-19. https://doi.org/10.52093/hara-202001-00001-000

(c) (i) $($ This is an open access article distributed under the terms of the Creative Commons Attribution License, which permits unrestricted use, distribution, and reproduction in any medium, provided the original author and source are credited.

\section{Introduction ${ }^{1}$}

This paper aims to give an explanation for the structure of ex. (1) below: ${ }^{2}$

1 This paper is a revised version of Zólyomi 2015, which itself is based on a talk given in Heidelberg in June 2014.

2 Royal inscriptions are quoted with reference to their number in RIME ( $1=$ Frayne 2007; 3/1 = Edzard 1997; 3/2 = Frayne 1997). P-numbers and Q-numbers refer to the catalogue-numbers of manuscripts and composite texts of the Cuneiform Digital Library Initiative Project (https://www.cdli.ucla.edu). Literary texts are quoted with reference to their designation and catalogue-number at the website of the Electronic Text Corpus of Sumerian Literature (http://etcsl.orinst.ox.ac.uk/). An electronic edition of all royal inscriptions mentioned in this paper can be found at the website of the Electronic Text Corpus of Sumerian Royal Inscriptions project (http://oracc.museum.upenn.edu/etcsri/).

In the Sumerian examples, the first line represents the utterance in standard graphemic transliteration; the second, a segmentation into morphemes; the third, a morpheme-by-morpheme glossing. Abbreviations used in the glosses: $\sim \mathrm{PF}=$ reduplication expressing present-future tense; $3=$ third person; $\mathrm{A}=$ agent (subject of a transitive verb); ABL = ablative case-marker or prefix; ABS = absolutive case-marker or prefix; $\mathrm{COM}$ = comitative case-marker or prefix; $\mathrm{COP}$ = copula; $\mathrm{DAT}$ = dative case-marker or prefix; DEM = demonstrative pronoun; FIN = finite-marker prefix; GEN = genitive case-marker; GN = geographical name; $\mathrm{H}$ = human; L1 = locative1 case-marker or prefix; L2 = locative2 case-marker or prefix; MID = middle prefix; $\mathrm{NEG}$ = negative prefix; $\mathrm{NH}$ = non-human; $\mathrm{P}$ = patient (object of a transitive verb); $\mathrm{PC}=$ predicate complement; $\mathrm{PF}$ = present-future or the marker of present-future; $\mathrm{PL}=$ plural; $\mathrm{PT}$ = preterit, or the marker of preterit; POSS = possessive enclitic or possessor; PT = preterit, or the marker of preterit; $\mathrm{S}$ = subject (of a transitive verb); SG = singular; SUB = subordinator suffix; SYN = syncopated verbal prefix; TERM = terminative case-marker or prefix; TL = tenseless; VEN = ventive prefix. 
EX. 1. Ur-Namma 28 1:10-13 (Girsu, 21st c.) (RIME 3/2.1.1.28) (Q000952)

\begin{tabular}{|c|c|c|}
\hline $\begin{array}{l}\mathrm{id}_{2}-\mathrm{da}, \\
\text { PC's poss }[\mathbf{i d}=\mathbf{a k}] \\
\text { PC's Poss }[\text { canal=GEN] }\end{array}$ & $\begin{array}{l}{ }_{\mathrm{d}}^{\mathrm{n}} \text { anna-gu } \\
{ }_{\mathrm{s}}[\text { gannal } \\
{ }_{\mathrm{S}}[\mathrm{GN}=\mathrm{ABS}]\end{array}$ & $\begin{array}{l}\mathrm{mu}-\mathrm{be}_{2}{ }^{3} \\
{ }_{\mathrm{PC}}[\mathrm{mu}=\mathbf{b e}=\varnothing]=\mathrm{am}-\varnothing \\
{ }_{\mathrm{PC}}[\mathrm{name}=3 . \mathrm{sG} \cdot \mathrm{NH} \cdot \mathrm{POSS}=\mathrm{ABS}]=\mathrm{COP}-3 . \mathrm{SG} \cdot \mathrm{S}\end{array}$ \\
\hline $\begin{array}{l}\mathrm{id}_{2} \\
{ }_{\mathrm{PC}}[\mathrm{id} \\
{ }_{\mathrm{PC}}[\mathrm{canal}\end{array}$ & $\begin{array}{l}\text { ki-sur-ra-kam, } \\
\text { kisura }=a k=\varnothing]=a m-\emptyset \\
\text { border }=\text { GEN=ABS] }=\text { COP-3.sG.S }\end{array}$ & 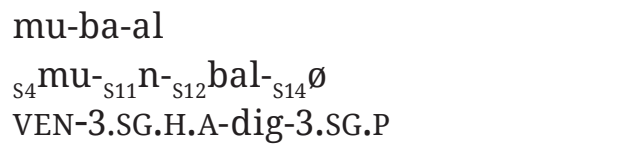 \\
\hline
\end{tabular}

Lit. "As for the canal, Nanna-gugal is its name, (it) is a border canal, he (= Ur-Namma) dug it." = "He (= Ur-Namma) dug a canal, whose name is Nanna-gugal, (and) which is a border canal."

Below are the translations given to this passage and the preceding clause by Th. Jacobsen, H. Steible, and D. Frayne. All three of them translate the word id "canal" as the object of the verb bal "to dig", and consider the name of the canal (Nanna-gugal) as a kind of modifier of the word "canal":4

"when he built the temple of Enlil, here dig the canal the name of which is ${ }^{d}$ Nanna-gú-gal as boundary-canal, ..."

“... als er <den Tempel> des Enlil gebaut hatte, den Kanal mit Namen Nannagugal ("Nanna (ist) Deichgraf') - es ist ein Grenzkanal - gegraben.”

“Wörtlich 'Des Kanals "Nanna (ist) der Deichgraf” sein Name,.”

"when he built the temple of the god Enlil, dug the canal named 'Nanna-gugal,' the boundary canal."

The non-literal translation given to ex. (1) above also considers id as the object of bal, and its name is translated with an appositive relative clause containing a non-verbal predicate.

These are contextual translations: if you have the word "canal", its name and the verb "to dig", then the sentence should mean that someone digs a canal with a certain name. Interpreting the word id "canal" as the object of verb bal "to dig" appears, however, to be in disagreement with the grammatical structure of ex. (1), where the word id is in the genitive and occupies a sentence-initial position. It is namely the left-dislocated possessor of the predicate complement (mu "name") of the initial copular clause in ex. (1); the subject of this clause is the name of the canal (nanna-gugal).

The first copular clause is followed by another one and by the clause whose finite verb is bal "to dig". The subject of the second copular clause is expressed solely by the 3rd ps. sg. pronominal suffix on the copula (-ø), and is co-referential with the left-dislocated id "canal" of the initial

In the morphemic segmentation of the finite verbal forms, subscript " $\mathrm{S}+$ number" refers to the verbal slots as discussed in Zólyomi 2017, 77-90.

3 The word form $\mathbf{m u}=\mathbf{b e}=\boldsymbol{\emptyset}=\mathbf{a m}-\boldsymbol{\emptyset}$ (name=3.SG.NH.POSS=ABS=COP-3.SG.S) is written as mu-be $\mathbf{e}_{2}$ until the end of the 3rd millennium BC. The use of the orthography mu-be $e_{2}$-em starts only with Amar-Suen in the royal inscriptions; cf., e.g., Amar-Suen 10 1:12 (RIME 3/2.1.3.10) (Q000985).

4 For similar translations cf., e.g., PSD B, 11 (§2.1.2.1.); Horowitz 1998, 85; Woods 2008, 115 (ex. 35); Rey et al. 2016, 26.

5 Jacobsen 1960, 178.

$6 \quad$ Steible 1991, II, 131 and 132.

7 Frayne 1997, 64. 
copular clause. ${ }^{8}$ Its predicate complement is the genitive construction id kisura=ak "border canal”.

I am aware of no explanation in the assyriological literature that would derive the usual translations of ex. (1) from its grammatical structure. The purpose of this paper is to provide an interpretation that is based on the grammatical analysis of the construction used in ex. (1).

The paper is structured as follows: Section 2 discusses biclausal constructions which consist of a copular and a finite, non-copular clause, and the two clauses share a participant. It will be argued that the predicate complement of the copular clause functions as a relative clause in these constructions, its head being the shared participant. Section 3 will show that Sumerian copular biclausal constructions are paratactic constructions. The predicate of the construction's copular clause functions as a paratactic relative clause. It contrasts with relative clauses of finite verbs which are formally marked as subordinate. Section 4 demonstrates that in copular biclausal constructions the choice that which participant of the copular clause will function as head is determined not by the syntactic but by the pragmatic function of the participants. The paper concludes with a summary of its main findings.

\section{Copular biclausal constructions}

Copular clauses in Sumerian are often used in a construction together with a finite, non-copular clause. In the following I will refer to this type of construction as copular biclausal construction. A typical example is ex. (2) below:

EX. 2. Gudea Cyl. A 8:10 = 13:26 (Girsu, 22nd c.) (ETCSL 2.1.7) (Q000377a)

\section{Copular clause}

\begin{tabular}{|c|c|c|c|}
\hline er $=A B S]$ & $\begin{array}{l}\mathrm{u}_{2} \\
\mathrm{PC}[\mathrm{u} \\
\text { PClant }\end{array}$ & $\begin{array}{l}\text { sikil } \\
\text { sikil-ø } \\
\text { pure-TL }\end{array}$ & $\begin{array}{l}\text { kur-ra-kam } \\
\text { kur }=a k=\varnothing]=a m-\varnothing \\
\text { mountain }=\text { GEN }=A B S]=C O P-3 . S G\end{array}$ \\
\hline
\end{tabular}

\section{Matrix clause}

izi-a

izi='a

fire $=\mathrm{L} 2 . \mathrm{NH}$

$$
\begin{aligned}
& b i_{2} \text {-si-si } \\
& { }_{\mathrm{S5}} \mathrm{b}^{-}{ }_{\mathrm{S} 10} \mathrm{i}{ }_{\mathrm{S} 11} \mathrm{n}{ }^{-}{ }_{\mathrm{S} 12} \mathrm{Si} \sim \mathrm{Si}^{-}{ }_{\mathrm{S} 14} \emptyset
\end{aligned}
$$

3.SG.NH-L2-3.SG.H.A-fill PL-3.SG.P

Lit. "The juniper is the pure plant of the mountains; he (= Gudea) put it onto the fire." = "He (= Gudea) put juniper, which is the pure plant of the mountains, onto the fire."

Ex. (2) consists of two clauses. The initial clause is copular "The juniper is the pure plant of the mountains". Its subject is the word li "juniper", its predicate complement is the genitive construction $\mathbf{u}$ sikil-ø kur=ak "the pure plant of the mountains". Both its subject and its predicate complement are in the absolutive case. Its predicate is a $3 \mathrm{rd} \mathrm{ps.} \mathrm{sg.} \mathrm{enclitic} \mathrm{copula:}=\mathbf{a m}-\boldsymbol{\emptyset}$. The second clause involves a finite non-copular verb: "He (= Gudea) put it (= the juniper) onto the fire.”

These two clauses could be used independently without any modification as simple sentences. The two clauses share a participant; the word li "juniper" functions as the subject in the first, while as the object in the second one.

8 For the most important characteristics of copular clauses in Sumerian, see Zólyomi 2014, 17-22 or Zólyomi 2017, 107-112. 
Copular biclausal constructions are characterized by a conceptual asymmetry. The "main" assertion is related to the finite verb in the matrix clause; the predicate of the copular clause functions only to provide some additional information about the shared participant.

It is this conceptual asymmetry that is reflected in the translation of Edzard: "He threw into the fire (twigs of) juniper, pure plants of the mountain". ${ }^{9}$ In Edzard's translation the predicate complement functions as an attributive apposition to the word li "juniper". The non-literal translation of ex. (2) above renders it as an appositive relative clause.

This conceptual asymmetry may also reveal itself in syntax. Consider exx. (3) and (4) below. Both examples contain subordinate clauses depending on a verb of oath. And in both examples one of the subordinate clauses is a copular clause.

EX. 3. NG 123 1-8 (Girsu, 21st c.) (P111431)

\begin{tabular}{|c|c|c|c|}
\hline $\begin{array}{l}\text { ku-li-sag }{ }_{9}-\mathrm{ge}_{2} \\
\text { kulisag=e } \\
\text { PN1=ERG }\end{array}$ & $\begin{array}{l}\text { mama-šu-hal-bi } \\
\text { s[amašuhalbi=ø] } \\
{ }_{\mathrm{c}}[\mathrm{PN} 2=\mathrm{ABS}]\end{array}$ & $\begin{array}{l}\text { geme }_{2} \\
\left.{ }_{\mathrm{PC}} \text { [geme= }=\varnothing\right]\end{array}$ & 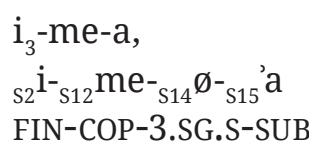 \\
\hline \multicolumn{4}{|c|}{ 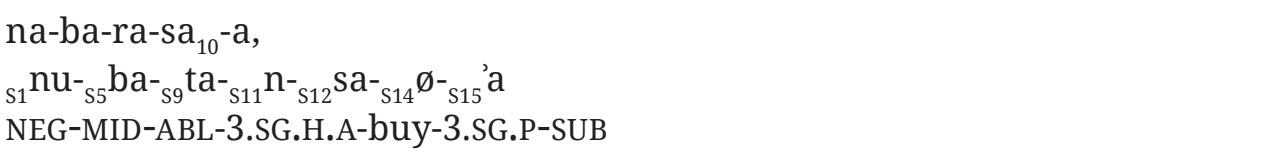 } \\
\hline $\begin{array}{l}\text { i-ta-e }{ }_{3}-\mathrm{a} \\
\text { itaea=ra } \\
\text { PN3=DAT.H }\end{array}$ & 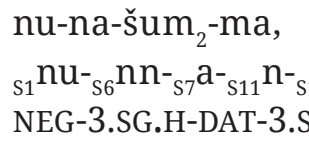 & 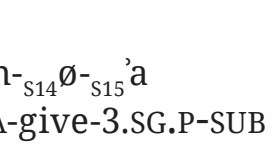 & \\
\hline \multicolumn{3}{|c|}{ 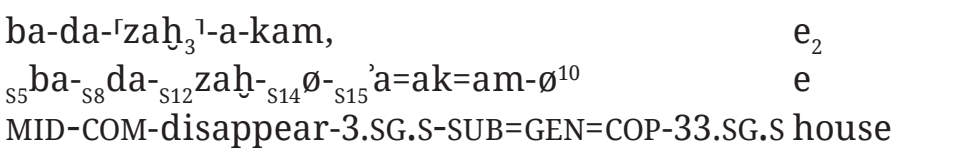 } & $\begin{array}{l}\text { nin-`mar`-ki-ka, } \\
\text { ninmarki=ak=‘a } \\
\text { DN=GEN=L1 }\end{array}$ \\
\hline $\begin{array}{l}\text { nam-erim }_{2}-\text { be }_{2} \\
\text { namerim=be }= \\
\text { oath=3.SG.NH.P }\end{array}$ & $\begin{array}{l}\text { in-kuc } \\
{ }_{\mathrm{s} 2} \mathrm{i}^{-}{ }_{\mathrm{s} 11} \mathrm{n} \\
\mathrm{FIN}-3 . \mathrm{s}\end{array}$ & $\begin{array}{l}\text { ud-s14 } ø \\
\text { A-cut-3.sG.P }\end{array}$ & \\
\hline
\end{tabular}

"In the temple in Ninmarki, Kuli-sag took the affirmatory oath that Ama-šuhalbi was a female slave, that he did not sell her, that he did not give her to Itaea, and that she did run away."

EX. 4. NATN 920 6-9 (Nippur, 21st c.) (P121617)

\begin{tabular}{|c|c|c|c|}
\hline $\begin{array}{l}\operatorname{lu}_{2}-\text { giri }_{17}-\mathrm{zal}, \\
{ }_{\mathrm{s}} \text { [lugirizal } \\
{ }_{[}[\mathrm{PN} 1\end{array}$ & $\begin{array}{l}\mathrm{lu}_{2} \text {-dinir-ra } \\
\text { ludinirak=ø] } \\
\text { PN2=ABS] }\end{array}$ & $\begin{array}{l}\text { šeš } \\
{ }_{\mathrm{PC}}^{[C \text { šeš }}\end{array}$ & $\begin{array}{l}\text { a-tu-me, } \\
\text { atu }=a k=\varnothing]=\text { ee-eš } \\
\text { PN3=GEN=ABS]=COP-3.PL.S }\end{array}$ \\
\hline
\end{tabular}

nu- $\mathrm{u}_{3}-\mathrm{ub}-g \mathrm{i}_{4}-g \mathrm{gi}_{4}-\mathrm{de}_{3}-\mathrm{s} \mathrm{a}$,

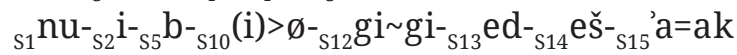

NEG-FIN-3.SG.NH-L2.SYN-return PF-PF-3.PL.S-SUB=GEN

9 Edzard 1997, 74.

10 Following the finite verb, the enclitic copula functions here as the marker of polarity focus; see Zólyomi 2014, 169-172. 


\begin{tabular}{|c|c|c|}
\hline $\mathrm{mu}$ & $\begin{array}{l}\text { lugal-be }{ }_{2} \\
\text { lugal }=\mathrm{ak}=\mathrm{be}=\varnothing\end{array}$ & 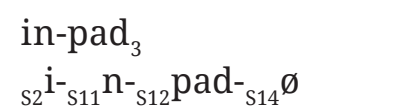 \\
\hline & king $=\mathrm{GEN}=\mathrm{POSS} \cdot 3 . \mathrm{SG} \cdot \mathrm{NH}=\mathrm{ABS}$ & FIN-3.SG.H.A-call-3.SG.P \\
\hline
\end{tabular}

"He (= Atu) swore by the king's name that Lu-girizal (and) Lu-dinira, who are the brothers of Atu, will not contest it (= Atu's adoption of a slave and appointment as his heir) (lit. "will not come back to it”)."

In ex. (3) the copular clause is:

${ }_{s}[\text { amašuhalbi }=\varnothing]_{\mathrm{PC}}[$ geme $=\varnothing]$ i-me- $\varnothing-\mathrm{a}$

"Ama-šuhalbi is a female slave"

In ex. (4) it is:

${ }_{s}\left[\right.$ lugirizal ludinirak=ø] ${ }_{\mathrm{PC}}[$ šeš atu=ak=ø]=me-eš

"Lu-girizal (and) Lu-dinira are the brothers of Atu"

The two copular clauses differ in their form, which in turn reflects a difference in their function. The copular clause in ex. (3) is one of the four statements confirmed by Kuli-sag in the oath. Its predicate is an independent, finite copular verb, which is formally marked as subordinate by the suffix -/'a/ just like the other three finite verbs in the oath. ${ }^{11}$

The predicate is an enclitic copula in the copular clause of ex. (4). It is formally therefore not subordinate, unlike the second, non-copular verb in the oath, which is formally marked as subordinate by the suffix -/a/. The copular clause in ex. (4) is clearly not a statement to be confirmed by the oath, rather its predicate provides some additional information about Lu-girizal and Ludinira, namely, that they are the brothers of the oath-taker.

In other words, ex. (4) may not be interpreted as saying "Atu swore by the king's name that Lu-girizal (and) Lu-dinira are the brothers of Atu, and that they will not contest it." The oath relates only to the statement that the two persons will not contest the adoption, but not to the statement that they are the brothers of Atu. The copular clause of this example is therefore subordinated only conceptually but not formally to the following clause.

Ex. (4) demonstrates clearly that the predicate of the copular clause is conceptually subordinate to that of the matrix clause in copular biclausal constructions, so translations like "He put juniper, which is the pure plant of the mountains, onto the fire” are justified.

\section{Paratactic relative clauses}

How are the copular biclausal constructions analysed in the earlier sumerological literature? Well, obviously not as biclausal constructions. In her grammar of Sumerian, M.-L. Thomsen clearly means examples like ex. (2) above when stating:

"The enclitic copula ... which can occur at the end of the [nominal] chain replaces, so to say, the appropriate case element." 2

What is meant is that one is missing the expected ergative case-marker in constructions like ex. (5) below.

\footnotetext{
11 The independent and the enclitic copula have a complementary distribution in Sumerian. See Zólyomi $2014,19-20$ or Zólyomi 2017, 110 about the morphosyntactic environments that determine which form is used.

12 Thomsen 1984, 53
} 
EX. 5. Gudea Cyl. A 1:12 (Girsu, 22nd c.) (ETCSL 2.1.7) (Q000377a)

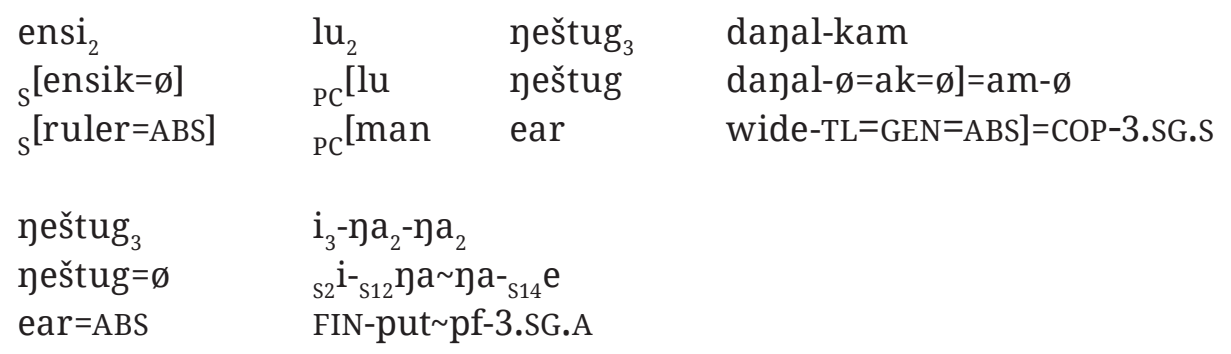

Lit. "The ruler is a man of wide ears, he is going to apply his wisdom." = "Being a man of wide wisdom, the ruler will act wisely."

Without the copula the first part of ex. (5) should be like the hypothetical ex. (6):

EX. 6.

*ensik lu [neštug danal- $\varnothing=\mathrm{ak}]=\mathrm{e}$

ruler man [ear wide-TL=GEN]=ERG

“the ruler, a man of wide ears ...”

Similar views are expressed by F. Karahashi who states:

"When the Sumerian particle -àm is attached to a constituent, it supersedes ordinary case-marking .... In other words, attachment of this particle causes neutralization of these case particles, as Falkenstein observed" ${ }^{13}$

In fact, Falkenstein's original description does more justice to the real character of the construction than that of Thomsen's or Karahashi's. His explanation for the apparent lack of case-markers was that "der ursprüngliche Satzcharacter die Setzung von Kasuszeichen verhindert”, ${ }^{14}$ and in another place of his seminal work on the grammar of the Gudea texts he states that

“Sätze mit der enklitischen Kurzform der Kopula ..., die von Haus aus selbständig sind, können ... als Glieder des nominalen Satzteils verwandt werden”.15

Both Thomsen's and Karahashi's formulation appear to miss the main characteristic of these constructions: they are biclausal. They expect case-markers where there should be no case-markers. The words which they expect to be case-marked are the predicate complements of a copular clause and not the constituent of the matrix clause with the finite non-copular verb.

A. Jagersma was the first who labelled the copular clause of the biclausal constructions corresponding to their function. He calls them copular relative clauses, but states that they "are never followed by a phrase-final clitic" ${ }^{16}$

By saying this, he contrasts them with the relative clauses of non-copular verbs, which are casemarked according to the function of their heads as in ex. (7) below. In Sumerian, the finite relative clause becomes the modifier of the noun that functions as the head of the relative clause.

\footnotetext{
13 Karahashi 2008, 89.

14 Falkenstein 1950, 32.

15 Falkenstein 1950, 32 (§89d).

16 Jagersma 2010, 706.
} 
EX. 7. Gudea Cyl. A 7:11-12 (Girsu, 22nd c.) (ETCSL 2.1.7) (Q000377a)

\begin{tabular}{|c|c|c|}
\hline inim & dnanše-e & mu-na-dug ${ }_{4}$-ga-aš, \\
\hline inim & [nanše $=e$ & 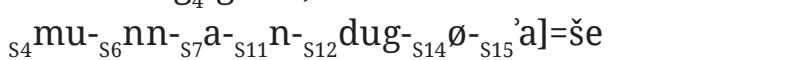 \\
\hline word & {$[\mathrm{DN}=\mathrm{ERG}$} & VEN-3.SG.H-DAT-3.SG.H.A-speak-3.SG.P-SUB]=TERM \\
\hline san & sig & ba-ši-nar \\
\hline say & $\operatorname{sig}-\varnothing=\varnothing$ & 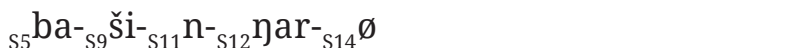 \\
\hline head & low-TL=ABS & MID-TERM-3.SG.H.A-put-3.SG.P \\
\hline
\end{tabular}

Lit. "He (= Gudea) set a low head to the words that Nanše told him." = "He (= Gudea) accepted what Nanše told him.”

In ex. (7) above, the relative clause nanše=e mu-nn-a-n-dug-ø-'a "that Nanše told him" structurally is the modifier of the word inim "word" that functions as its head. As the relative clause syntactically is the modifier of its head, the case-marker that indicates the function of the head noun in the matrix clause follows the relative clause.

The idiom sag sig — nar "to lower the head" case-marks the participant before which/whom one lowers the head with the terminative, consequently here the relative clause is followed by a terminative case-marker. The relative clause is syntactically subordinate, so its finite verb contains a subordinate suffix $-/ \mathbf{a} / .^{17}$

Unfortunately, Jagersma's (2010) grammar does not provide an explanation of the apparent lack of the phrase-final clitic in copular relative clauses either.

There exists thus a construction in Sumerian that involves two clauses; both could be used independently as a simple, non-subordinate clause. The predicate of the first, copular clause of these constructions, in fact, functions as a relative clause modifying the participant shared by the two clauses of the construction. This construction differs from sentences involving a non-copular relative clause, in which the relative clause is marked formally subordinate with a subordinate suffix -/a/. The copular biclausal constructions thus contrast with sentences involving a non-copular relative clause in the lack of formally marked syntactic subordination. In other words, the copular clause of a copular biclausal construction stands not in a subordinate but in a paratactic relation with its matrix clause.

In an article about relative clause formation in African languages, T. Kuteva and B. Comrie recognize a relativization strategy that is very similar to the one just suggested for Sumerian. They say:

"The paratactic relativization strategy involves cases where the 'relative' clause contains the fullfledged head and is the same as an unmarked simple (declarative) clause; the relative and main clauses are only very loosely joined together."18

They refer to sentences like ex. (8) below as a possible English parallel:

\section{EX. 8.}

“That man just passed by us, he introduced me to the Chancellor of the University yesterday.” This strategy is attested in Amele (spoken in Papua New Guinea):

17 See Zólyomi 2017, 96-100 for relative clauses in Sumerian.

18 Kuteva-Comrie 2005, 212. 
EX. 9.19

$\begin{array}{llll}\text { mel } & \text { mala } & \text { heje } & \text { on } \\ \text { boy } & \text { chicken } & \text { illicit } & \text { take.3.SG.S.REM.PAST } \\ ((\mathrm{mel}) & \text { eu }) & \text { busali } & \text { nu-i-a } \\ \text { boy } & \text { that } & \text { run away } & \text { go-3.SG.S-TOD.PAST }\end{array}$

Lit. "The boy stole the chicken; (that boy) ran away. = "The boy that stole the chicken ran away."

They describe the example as follows:

'mel 'boy' is the 'relativized' noun in the 'relative' clause. This nominal can optionally be referred to in the following 'matrix' clause either by the demonstrative eu 'that' or, if clarification is needed, mel eu 'boy that'. What links the two clauses is the rising intonation at the end of the first clause. This indicates that it is not a final clause and is in either a subordinate or coordinate relationship with the following clause. ${ }^{.20}$

Sumerian copular biclausal constructions appear to be a manifestation of the paratactic relativization strategy as defined by Kuteva and Comrie. The initial copular clause contains the constituent that functions as the head of the relative clause, and the clause is formally the same as a simple non-subordinate copular clause. The two clauses share a participant and the predicate complement of the initial copular clause is interpreted as the modifier of the shared participant. ${ }^{21}$

\section{The head of the paratactic relative clauses}

What is the relevance of recognizing the existence of paratactic relativization in Sumerian to the interpretation and analysis of ex. (1)? This is the subject of the concluding part of the paper.

In the copular biclausal constructions discussed so far, the copular clause consisted of only a subject and a predicate complement. In ex. (2), for example, the subject is the word li "juniper", and the predicate complement attributes a property to it. It is therefore natural that the subject functions as the head of the paratactic relative clause. But copular clauses may have additional constituents. Consider, for example, ex. (10) below, another copular clause about the name of something.

EX. 10. Ur-Namma 19 2:7-8 (Ur, 21st c.) (RIME 3/2.1.1.19) (Q000946)

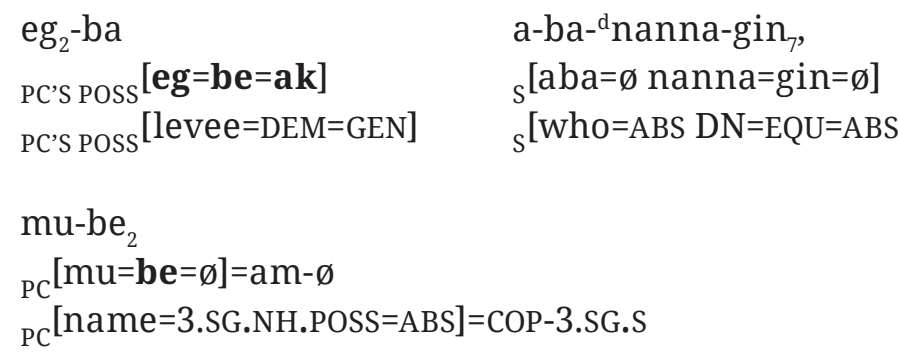

“As for that levee, 'Who-is-like-Nanna?’ is its name.”

In this example, the word $\mathbf{e g}=$ "levee", the possessor of the predicate complement (= mu "name") is left-dislocated and occupies a sentence-initial position in front of the subject, the name of the

19 Kuteva - Comrie, 2005, 212, ex. 9. The abbreviations are REM.PAST = remote past, TOD.PAST = today past.

20 Kuteva - Comrie 2005, 213.

21 See Deutscher 2000 about parataxis in Akkadian, the other main language of ancient Mesopotamia. Deutscher also discusses parataxis in Sumerian, although not in relation to copular relative clauses (2000, 153-155). 
levee. The left-dislocated possessor functions as the topic of the clause, ${ }^{22}$ i.e. the clause will be construed as being about the possessor; as the translation of ex. (10) indicates.

The structure of ex. (10) is exactly the same as the structure of the initial copular clause in ex. (1). Ex. (1) too starts with a left-dislocated possessor (id = "canal"). One may wonder what happens when a copular clause similar to ex. (10) will be part of a copular biclausal construction and function as paratactic relative clause? In particular, which of its constituents will function as the head of the relative clause, the subject or the left-dislocated possessor?

The customary translations of ex. (1) indicate that the answer to this question is the left-dislocated possessor. Ex. (1) makes sense only if one assumes that the left-dislocated possessor of the predicate complement, i.e., the word id "canal" will function as the head. This finding has important consequences for the interpretation of copular biclausal constructions. It suggests that choice of the head is determined not by the syntactic but by the pragmatic function of the participants.

In ex. (2) the subject and the topic of the initial copular clause are the same participant. But in ex. (1) (and also in ex. [11] below) the participants functioning as the subject and the topic are different. ${ }^{23}$ In these examples the head of the paratactic copular relative clause will be the participant that functions as the topic of the copular clause, i.e., the left-dislocated possessor of the predicate complement.

The meaning of ex. (1) thus follows from the way paratactic copular relative clauses select their head. The head of these constructions will be the participant that functions as the topic of the copular clause.

The passage in ex. (1) is not the only one in which the head of the paratactic copular relative clause is a left-dislocated possessor. The same construction occurs in a well-known and frequently discussed passage of the inscription E-ana-tum 5, see ex. (11) below. Because of its oddity G. Marchesi suggested that text is corrupt and should be emended. ${ }^{24}$ But there is no need for emendation. In ex. (11) too, it is the left-dislocated possessor of the predicate complement that is interpreted as the head of the paratactic relative clause "E-ana-tum, whose own name is E-ana-tum".

EX. 11. E-ana-tum 5 5:10-17 (Girsu, 25th c.) (RIME 1.9.3.5) (Q001057)

\begin{tabular}{|c|c|c|c|}
\hline $\begin{array}{l}\mathrm{e}_{2} \text {-an-na-tum } \\
\text {-ma, } \\
\text { PC'S Poss }^{\prime}[\text { eanatum }=\text { ak] } \\
\text { PC'S Poss }[\mathrm{RN}=\mathrm{GEN}]\end{array}$ & $\begin{array}{l}\mathrm{e}_{2} \text {-an-na-tum } \\
\mathrm{s}_{\mathrm{S}}[\mathrm{eanatum}=\varnothing] \\
{ }_{\mathrm{S}}[\mathrm{RN}=\mathrm{ABS}]\end{array}$ & $\begin{array}{l}\mathrm{mu} \\
{ }_{\mathrm{PC}}^{[\mathrm{mu}} \\
{ }_{\mathrm{PC}}^{[\text {name }}\end{array}$ & $\begin{array}{l}{ }^{\mathrm{ru}_{2}} \text {-rum-ma-ne }{ }_{2}{ }^{\top}, \\
\text { urum=ane=ø]=am- } \varnothing] \\
\text { own=3.SG.H.POSS=ABS]=COP-3.SG.S] }\end{array}$ \\
\hline $\begin{array}{l}\mathrm{mu} \\
{ }_{\mathrm{PC}}[\mathrm{mu} \\
\mathrm{PC} \text { name }\end{array}$ & $\begin{array}{l}\mathrm{rGIR}_{3} \text { '. GIR }-\mathrm{Ge}_{2}, \\
\ldots=\text { ane }=\varnothing] \\
\ldots=3 . \text { SG.H.POSS }=\mathrm{ABS}]\end{array}$ & $\begin{array}{l}\text { llum-ma- } \\
{ }_{s}^{[l u m a=\varnothing} \\
{ }_{S}^{[P N=A B S}\end{array}$ & - $-625^{25}$ \\
\hline
\end{tabular}

22 See Zólyomi 2017, 53-55 on left-dislocated genitive constructions in Sumerian.

${ }^{23}$ For a typology of Sumerian copular clauses in terms of their information structure, see Zólyomi 2014, 27-55.

24 Marchesi 2006, 123.

25 It follows from the analysis presented here that the A sign of lum-ma-a must represent a writing for the 3rd ps. sg. enclitic copula; superseding my former suggestion in Zólyomi 2010. For previous suggestions see Marchesi 2006, $22^{86}$ and 124.

Note that also in Iri-ka-gina 1 (Girsu, 24th c.) (RIME 1.9.9.1) (Q001124) the verbal form is written differ-

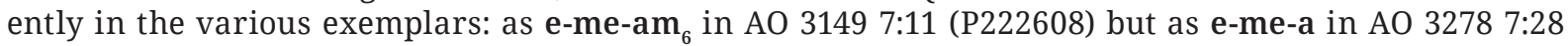
(P222607). 


\begin{tabular}{|c|c|c|c|}
\hline 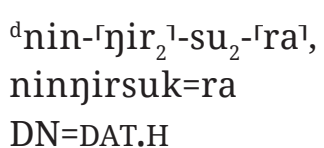 & $\begin{array}{l}\mathrm{id}_{5} \\
\text { id } \\
\text { canal }\end{array}$ & $\begin{array}{l}\text { gibil, } \\
\text { gibil- } \varnothing=\varnothing \\
\text { new-TL=ABS }\end{array}$ & 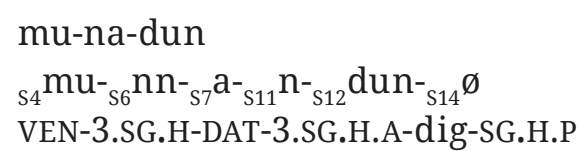 \\
\hline
\end{tabular}

“(In those days), E-ana-tum, whose own name is E-ana-tum, (but) whose ... name is Luma, dug a new canal for Ninjirsu.”

The oddity of this example is due to the fact that the person whose name is specified by the subject is referred to by the very same name in the left-dislocated possessor of the predicate. Although the word $\mathbf{e}_{2}$-an-na-tum ${ }_{2}$ occurs twice in the initial copular clause of ex. (11), the referents of the two words are different. The left-dislocated possessor refers to the person called E-anatum, ruler of Lagaš, while the subject refers to the name "E-ana-tum".

The reason for this odd construction is, however, clear: the initial copular clause contrasts with the subsequent one, the former gives E-ana-tum's ordinary name, while the latter gives another name (of unknown nature) of his.

Ex. (1) and ex. (11) are constructions involving more than one paratactic copular relative clauses. In both of them a clause with a finite non-copular verb is preceded by two copular clauses, both of which function as paratactic relative clause.

In ex. (1) the head of the paratactic copular relative clauses is the word id "canal". This participant functions as the left-dislocated possessor of the word mu "name" in the first copular clause, as the subject in the second copular clause, and as object of the verb bal "to dig" in the third, non-copular clause.

In ex. (11) the head of the paratactic copular relative clauses is the word eanatum referring to the person. This participant functions as the left-dislocated possessor of the expression mu urum "own name" in the first copular clause, as the possessor of the obscure expression mu GIR3.GIR3 “... name” in the second copular clause, and as the agent of the verb dun "to dig” in the third, non-copular clause.

\section{Summary}

The main findings of this paper may be summarized as follows:

1. Copular clauses may function as paratactic relative clauses in copular biclausal constructions in Sumerian.

2. In these constructions the head of the paratactic relative clause is the topic of the copular clause, which may be either the subject of the copular clause (exx. [2], [4], and [5]) or the left-dislocated possessor of the predicate complement (exx. [1] and [11]).

\section{References}

Deutscher, G. 2000: Syntactic Change in Akkadian. The Evolution of Sentential Complementation. Oxford.

EdZARD, D. O. 1997: Gudea and His Dynasty. (The Royal Inscriptions of Mesopotamia. Early Periods 3, I) Toronto. https://doi.org/10.3138/9781442675551

Falkenstein, A. 1950: Grammatik der Sprache Gudeas von Lagaš. II: Syntax. (Analecta Orientalia 29) Roma.

Frayne, D. 1997: Ur III Period (2112-2004). (The Royal Inscriptions of Mesopotamia. Early Periods 3, II) Toronto. https://doi.org/10.3138/9781442657069

Frayne, D. 2007: Presargonic Period (2700-2350 BC). The Royal Inscriptions of Mesopotamia. Early Periods 1) Toronto. https://doi.org/10.3138/9781442688865

Horowitz, W. 1998: Mesopotamian Cosmic Geography. (Cuneiform Monographs 8). Winona Lake. 
JACOBSEN, T. 1960: The Waters of Ur. Iraq 22, 174-185. https://doi.org/10.2307/4199683

JaGersma, A. H. 2010: A descriptive grammar of Sumerian. PhD Dissertation, Universiteit Leiden.

KARAHASHI, F. 2008: Sumerian enclitic -àm and Akkadian enclitic -ma: From copula to focus marker. In: BIGGS, R. D. ET AL. (eds.): Proceedings of the 51st Rencontre Assyriologique Internationale Held at the Oriental Institute of the University of Chicago, July 18-22, 2005. (Studies in Ancient Oriental Civilization 62) Chicago, 85-91.

Kuteva, T. - Comrie, B. 2005: The typology of relative clause formation in African languages. In: Voeltz, F. K. E. (ed.): Studies in African Linguistic Typology. (Typological Studies in Language 64) Amsterdam, 209-228. https://doi.org/10.1075/tsl.64.12kut

MARCHeSI, G. 2006: Lumma in the Onomasticon and Literature of Ancient Mesopotamia. (History of the Ancient Near East. Studies 10) Padova.

Rey, S. - Husain, F. - Lecompte, C. 2016: Tello/Girsu. Preliminary Report of the April 2015 Reconnaissance. Sumer 62, 9-35.

Steible, H. 1991: Die neusumerischen Bau- und Weihinschriften, I-II. (Freiburger altorientalische Studien 9) Stuttgart.

Thomsen, M.-L. 1984: The Sumerian Language. An Introduction to Its History and Grammatical Structure. (Mesopotamia 10) Copenhagen.

Woods, C. 2008: The Grammar of Perspective. The Sumerian Conjugation Prefixes as a System of Voice. (Cuneiform Monographs 32). Leiden - Boston.

Zólyomi, G. 2010: On G. Marchesi’s Understanding of Eanatum 5 v 9-17. Cuneiform Digital Library Notes 2010:2. [https://cdli.ucla.edu/pubs/cdln/php/single.php?id=10]

Zólyomi, G. 2014: Copular Clauses and Focus Marking in Sumerian. Warsaw - Berlin. https://doi. org $/ 10.2478 / 9783110401707$

ZóLYomi, G. 2015: Csatornák, nevek és kopulás vonatkozói mellékmondatok a sumerben. In: BÁcs, T. ET AL. (eds.): Aegyptiaca et Assyriaca. Tanulmányok az Eötvös Loránd Tudományegyetem Ókortudományi Intézetéböl. (Antiqua et Orientalia 5) Budapest, 245-254.

Zólyomi, G. 2017: An Introduction to the Grammar of Sumerian. With the collaboration of Sz. Jáka-Sövegjártó and M. Hagymássy. Budapest. 



\title{
An abbreviated version of En-metena 1 from the Sulaymaniyah Museum
}

\author{
Ardalan Khwshnaw*, Gábor Zólyomi ${ }^{\ddagger}$ \\ * - Salahaddin University, Erbil. Email: khwshnaw.ardalan@gmail.com \\ $\ddagger-$ Department of Assyriology and Hebrew Studies, Eötvös L. University, Budapest. Email: zolyomi.gabor@ \\ btk.elte.hu
}

\begin{abstract}
This paper contains the publication of a previously unknown manuscript of En-metena 1 (RIME 1.9.5.1), which is kept in the Sulaymaniyah Museum in Iraq. The new manuscript contains an abbreviated version of the text compared to the text on the Louvre cone and the Yale jar. Although only about the half of the round object that carries the text is preserved, it may be estimated that the Sulaymaniyah manuscript originally was at least 89 lines shorter than the Louvre and the Yale manuscripts.
\end{abstract}

Keywords: Sumerian, En-metena, Lagaš, royal inscriptions, 3rd millennium BC

Cite as Khwshnaw, A., Zólyomi, G. 2020: An abbreviated version of En-metena 1 from the Sulaymaniyah Museum. Hungarian Assyriological Review 1, 21-37.

https://doi.org/10.52093/hara-202001-00002-000

(c)(i) $($ This is an open access article distributed under the terms of the Creative Commons Attribution License, which permits unrestricted use, distribution, and reproduction in any medium, provided the original author and source are credited.

\section{Introduction}

This joint paper is the publication of a previously unknown manuscript of En-metena 1 (RIME 1.9.5.1) (CDLI Q001103) ${ }^{1}$, which is kept in the Sulaymaniyah Museum in Iraq, its catalogue number is T.3860. ${ }^{2}$ The manuscript is registered on the website of CDLI with the P-number P481719. The text is unprovenanced, it was acquired by the Museum on 22 December 2010. T.3860 is a spherical, wheel made, jar-like clay object. The fragmentary object measures $11,8 \times 13,2 \mathrm{~cm}$ at its base. Only about the half of the round object that carries the text is preserved; consequently, its preserved 64 lines may represent only about less than half of its original lines. It has four columns.

En-metena 1 has had five manuscripts known until now: AO 3004 (CDLI P222532), NBC 2501 (CDLI P222533), AO 4443 (CDLI P222534), VAT 16438 (CDLI P418029), and UA-4743 (= IM 191931) (CDLI

1 For editions of En-metena 1, see Steible and Behrens 1982, I, 230-245; II, 112-122 and Frayne 2007, 194199. An electronic edition of En-metena 1 and all the texts discussed in this paper are available at the website of the Electronic Text Corpus of Sumerian Royal Inscriptions project (http://oracc.museum.upenn.edu/etcsri). The royal inscriptions are quoted with reference to their number in RIME 1 (= Frayne 2007).

2 We thank to Mr. Hashim Hama Abdullah, director of the Sulaymaniyah Museum, for his kind permission to publish T.3860. We are grateful to Mr. Hemn Nuri, Mr. Adel, and Ms. Hazha for their help in obtaining photos of it. A photo of the object was published earlier in Al-Asadi 2015, 108; we are grateful for this reference to Farouk Al-Rawi and Khalid Salim Ismael. 
P513465). ${ }^{3}$ The provenience of the first three is unknown as they were acquired from dealers but are likely to come from the area of Girsu. ${ }^{4}$ VAT 16438 is from Uruk.

IM 191931 is a foundation brick found in Umm Al-Aqarib in 2002. ${ }^{5}$ It is a flat brick, written only on its obverse. ${ }^{6}$ Its preserved five columns contain the text from the beginning, the last preserved line corresponds to 1. 2:11 on the Louvre cone. As each of its columns contained originally approx. 10 lines, it is unlikely that IM 191931 contained the whole text as it is known from the Louvre and the Yale manuscripts, since that would require 20-22 columns.

\section{The relationship of the new manuscript with the Louvre and the Yale mss.}

The inscription on the Sulaymaniyah manuscript is arranged into four columns. Table 1 below shows the correspondence between the first lines of its columns and the lines of the Louvre cone and the Yale jar:?

\begin{tabular}{|l|l|l|l|}
\hline & T.3860 & AO 3004 & NBC 2501 \\
\hline & $1: 1(12$ II.) & $1: 1$ & $1: 1$ \\
\hline & $2: 1(18$ II.) & $1: 26(25$ I..) & $1: 26(25$ II.) \\
\hline & $3: 1(19$ I.) & $2: 35(50$ I.) & $3: 19(56$ I..) \\
\hline & $4: 1(15$ I..) & $6: 2(113$ II.) & $6: 14(111$ II.) \\
\hline last line & $4: 8^{\prime}$ & $6: 29(27$ I.) & $6: 40(28$ I..) \\
\hline
\end{tabular}

TABLE 1

Approximately half of the original object that carries the new manuscript is preserved. So, one may assume that approximately half of the lines are preserved in each column. Due to the shape of T.3860 col. 1 has the least lines. Col. 2 and 3 are longer and contain approximately the same number of lines. Col. 4. has slightly less lines than col. 2. and 3.

It is unlikely that any lines were skipped from the introductory part of En-metena 1 in the new manuscript, one may therefore safely assume that its first column contained 25 lines. The same can be assumed about the last part of the composition: the end of En-metena's blessing (see the commentary to 3:11'-4:7 below) and the final curse probably remained intact. Consequently, the last column of the new manuscript must have contained around 28 lines, which more or less corresponds to the number at which we arrive if we double the number of lines preserved in col. 4 .

The number of the preserved lines in the second and the third column are 18 and 19 respectively. The ms. contains a blank strip separating the beginning and the end of the columns; one may therefore estimate that they both contained around 38 lines originally.

3 AO 3004 will be referred to as the Louvre cone and NBC 2501 as the Yale jar throughout this paper.

4 See Cooper 1986, 56, note 1 and Marzahn 1997, 93.

5 Almamori 2014, 11.

6 Information kindly provided by Almamori (email 15/12/2018).

7 The numbers in brackets in the column of the new manuscript show the number of the preserved lines in each column. The numbers in brackets in the columns of the Louvre and the Yale manuscripts show the number of lines on these manuscripts between the lines that correspond to the first lines of the columns on the new manuscript. In the last row of the tablet, the numbers in brackets show the number of lines on the Louvre and the Yale manuscripts between the lines that correspond to the first and the last line of the 4 th column of the new manuscript. 


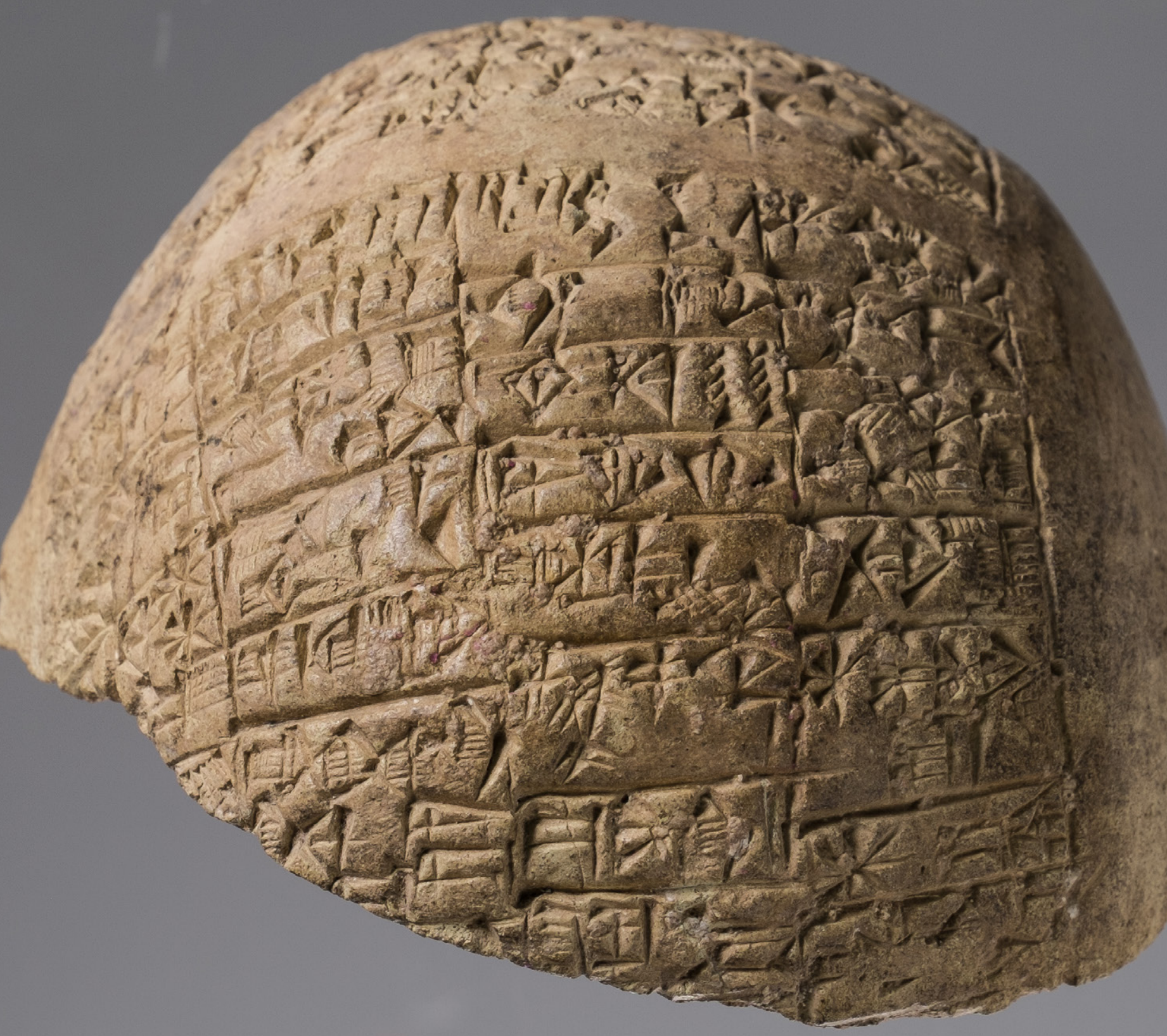

FIGURE 1. The beginning of cols. 2-4. Photo courtesy of the Sulaymaniyah Museum.

The gap in col. 2 of the new manuscript, the gap between 2:6 and 2:1', must have contained approx. 19 lines; while the gap in col. 3, the gap between 3:8 and 3:1' must have contained approx. 20 lines. Table 2 below shows how many lines in the Louvre cone and the Yale jar correspond to the gaps in column 2 and 3 of T.3860. The 5th column of Table 2 shows the number of omitted lines in the new manuscript calculated on the basis of these correspondences.

\begin{tabular}{|l|l|l|l|l|}
\hline & gap in T.3860 & A0 3004 & NBC 2501 & omitted lines in T.3860 \\
\hline col. 2 & approx. 19 II. & $1: 32-2: 21=32$ II. & $2: 1-3: 5=38$ II. & approx. 12-18 II. \\
\hline col. 3 & approx. 20 II. & $3: 38-5: 8,5: 12=46$ I. & $4: 28-5: 31,5: 35=46$ II. & approx. 26 II. \\
\hline
\end{tabular}




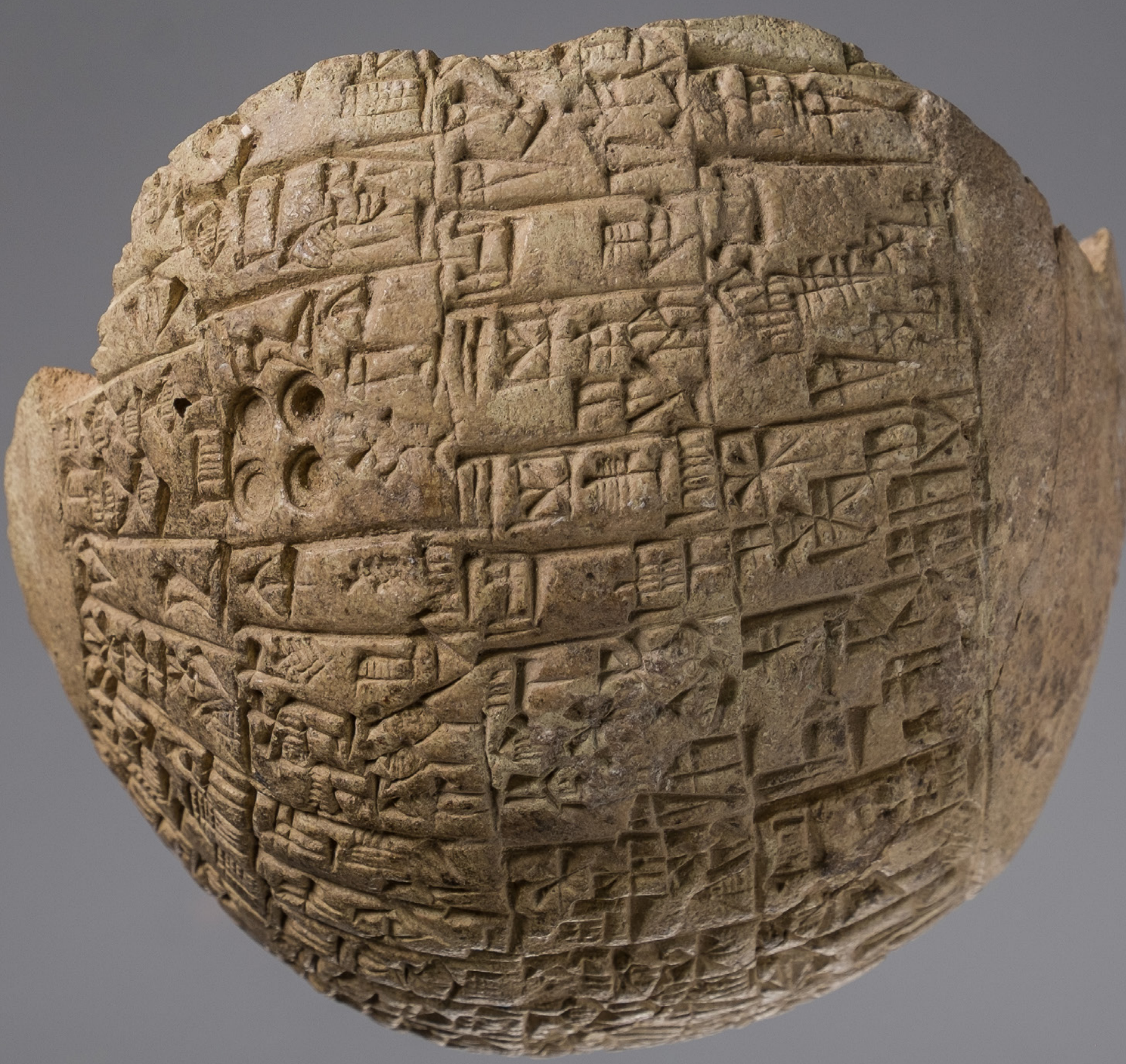

FIGURE 2. The beginning of the text of cols. 2-4 after the gap. Photo courtesy of the Sulaymaniyah Museum.

As regards col. 3, on the basis of the preserved text, we can know certainly that the Sulaymaniyah manuscript skips additional $37+12$ or $13^{8}$ lines in comparison with the Louvre cone and the Yale jar, as it omits 1l. 2:39-3:33, 5:20-6:1 in the Louvre, and 1l. 3:23-4:23, 6:1-13 in the Yale manuscript. In col. 3 of the new manuscript the scribe therefore omitted altogether approximately 76-77 lines as compared to the text of the Louvre and Yale manuscripts.

In sum, the Sulaymaniyah manuscript originally was at least 89 lines shorter than the Louvre and the Yale manuscripts, which have 209 and 220 lines respectively. ${ }^{9}$

The changes in the Sulaymaniyah manuscript may seem unique, but the other manuscripts are not uniform either. The text En-metena 1 is in fact a modern construct created by the modern editions which may conceal the differences in the mss. The passage below is translated by J. Cooper like this:

8 L. 5:30 of the Louvre ms. is written in two lines, 6:11-12 on the Yale ms.

9 The other three manuscripts are too fragmentary to estimate the number of their lines. 
"He extended the (boundary-) channel from the Nun-canal to the Gu'edena, leaving (a) 215 nindan (1290 m.) (strip) of Ningirsu's land under Umma's control and establishing a no man's land there." ${ }^{10}$

\begin{tabular}{|c|c|c|c|}
\hline & AO 3004 & NBC 2501 & \\
\hline $2: 1$ & eg $_{2}-$ be $_{2} \mathrm{id}_{2}$-nun-ta & $\mathrm{eg}_{2}-\mathrm{be}_{2} \mathrm{id}_{2}$-nun-ta & $2: 12$ \\
\hline $2: 2$ & gu $_{2}$-edin-na-še ${ }_{3}$ & gu $_{2}$-edin-na-še ${ }_{3}$ & $2: 13$ \\
\hline \multirow[t]{7}{*}{$2: 3$} & $\mathrm{ib}_{2}$-ta-ni-e $\mathrm{e}_{3}$ & $\mathrm{ib}_{2}$-ta-ni-e $\mathrm{e}_{3}$ & $2: 14$ \\
\hline & & ašag d nin-nir ${ }_{2}$-su-ka & $2: 15$ \\
\hline & & $\begin{array}{l}3 \times 60+3 \times 10+1 / 2 \\
\text { eše }_{2}{ }^{\text {ninda }} \text { ninda }_{x}(D U)\end{array}$ & $2: 16$ \\
\hline & & $\mathrm{a}_{2} \mathrm{umma}^{\mathrm{ki}-\check{s}_{3}}$ & $2: 17$ \\
\hline & & mu-taka & $2: 18$ \\
\hline & & ašag lugal nu-tuku & $2: 19$ \\
\hline & & $\operatorname{ni}^{-k r_{x}}(\mathrm{DU})^{11}$ & $2: 20$ \\
\hline $2: 4$ & $\mathrm{eg}_{2}$-ba na-ru ${ }_{2}-\mathrm{a}$ & $\mathrm{eg}_{2}$-ba na-ru $\mathrm{u}_{2}-\mathrm{a}$ & $2: 21$ \\
\hline $2: 5$ & e-me-sar-sar & e-me-sar-sar & $2: 22$ \\
\hline
\end{tabular}

Actually, we have two different versions of this passage; NBC 2501 adds a 6 lines long section providing supplementary information about the border between Lagaš and Umma (the underlined part of the translation exists only in either of the mss.):

Louvre cone: "He extended its (= the demarcated border's) dyke from the Id-nun canal to the Gu-edena. He set up inscribed stelae everywhere along the dyke.”

Yale jar: "He extended its (= the demarcated border's) dyke from the Id-nun canal to the Gu-edena. He set aside a 215 nindan (wide strip of) Ninnirsu's land along the border of Umma and turned it into a no-man's land. He set up inscribed stelae everywhere along the dyke.”

10 Cooper 1986, 55. Note that Cooper's translation contains a contradiction: if the strip of land had been left under Umma's control, then it could not have functioned as "no man's land". His translation of $\mathbf{a}_{2}$ umma-še ${ }_{3} \mathbf{m u}_{\text {-taka }}$ is also questionable grammatically. With verbs whose meaning involves neither physical nor metaphoric movement, the terminative may express not destination, but location next to, along something (cf. Balke 2006, 207-208 and Zólyomi 2017, 198, exx. [375]-[377]). A “no man's land” should function as a buffer zone excluding the possibility of a sudden and unnoticeable entrance into one's territory. If it lies on the enemy's side, it cannot fulfill this function. A translation like "He set aside a 215 nindan (wide strip of) Ninnirsu's land along the border of Umma” may reflect better the actual situation.

Cooper's translation may also follow from his understanding of $\mathbf{e g}_{2}$ as a levee with a canal on its top. If it is used as a canal it would not make sense to set aside a buffer zone on Lagašs side of the border. Understanding $\mathbf{~ e g}_{2}$ as a bund would support the translation suggested by this paper; cf. the pertinent remarks of Pemberton et al. (1988, 216): “The redefinition of eg would have a major effect on some of the discussions of the topography of the south, especially Lagash .... In particular note that the subject of the long-running dispute between Lagash and Umma would not have been a canal, but a boundary bund. It has always seemed difficult to me that it should have been a water-course, which would not only have required co-operative maintenance but also have constituted a permanent subject of contention, since neither side could control the other's access to and consumption of water.”

11 On the form of an initial locative1 prefix in transitive preterite verbal forms, see Jagersma 2010, 470-473 and Zólyomi 2017, 204-205; note that Jagersma’s description uses a different terminology. 
Here one may say that either the text of the Louvre cone presents an abbreviated version, or the text of the Yale jar presents an extended version of En-metena 1. But the variations in the passage below indicate the neither account may be true.

\begin{tabular}{|c|c|c|c|}
\hline & AO 3004 & NBC 2501 & \\
\hline 3:38 & eg $_{2}$ ki-sur-ra & $\mathrm{eg}_{2}$ ki-sur-ra & $3: 28$ \\
\hline $4: 1$ & ${ }^{\mathrm{d}}$ nin-nir ${ }_{2}$-su-ka & ${ }^{\mathrm{d}}$ nin-nir ${ }_{2}$-su-ka & $3: 29$ \\
\hline $4: 2$ & $\mathrm{eg}_{2}$ ki-sur-ra & $\mathrm{eg}_{2}$ ki-sur-ra & $3: 30$ \\
\hline $4: 3$ & ${ }^{\mathrm{d}}$ nanše & ${ }^{\mathrm{d}}$ nanše & $3: 31$ \\
\hline $4: 4$ & im-dub-ba & im-dub-ba & $3: 32$ \\
\hline $4: 5$ & ${ }^{d}$ nin-nir ${ }_{2}$-su-ka & ${ }^{\mathrm{d}}$ nin-nir ${ }_{2}$-su-ka & $3: 33$ \\
\hline $4: 6$ & $\mathrm{gu}_{2}{ }^{\text {id2idigna-še }}{ }_{3} \mathrm{yal}_{2}$-la & & \\
\hline $4: 7$ & $\mathrm{gu}_{2}-\mathrm{gu}_{2} \operatorname{\eta ir}_{2}-\mathrm{su}^{\mathrm{ki}}-\mathrm{ka}$ & & \\
\hline \multirow[t]{3}{*}{$4: 8$} & nam-nun-da-ki-nar-ra & nam-nun-da-ki-nar-ra & $3: 34$ \\
\hline & & ${ }^{d}$ en-lil ${ }_{x}\left(E_{2}\right)-l a_{2}$ & $3: 35$ \\
\hline & & den-ki-ka & $3: 36$ \\
\hline $4: 9$ & dnin-ḩur-say-ka & dnin-ḩur-san-ka & $3: 37$ \\
\hline $4: 10$ & a-e $i_{3}-m i-e_{3}$ & a-e $i_{3}-m i-e_{3}$ & $3: 38$ \\
\hline
\end{tabular}

Louvre cone: "He washed away the boundary dyke of Ninnirsu, ${ }^{12}$ the boundary dyke of Nanše, (which form) the boundary of Ninnirsu along the bank of the Tigris on the territory of Nirsu, the Namnunda-kinara of Ninhursana.

Yale jar: "He washed away the boundary dyke of Ninnirsu, the boundary dyke of Nanše, the Namnunda-kinara of Enlil, Enki, and Ninhursaya."

Here the Louvre cone specifies the location of Ninnirsu's boundary in 4:6-7; while the Yale jar names two additional deities in $3: 35-36 ;{ }^{13}$ and it is impossible to decide which version represents the "original" one.

The variations in the passages discussed above and those of the Sulaymaniyah ms. (see below) indicate that Early Dynastic royal inscriptions as texts were much less standardized than our modern editions may imply. Manuscripts assigned by us to a single text may vary considerably, reflecting the creativity of the composers who may have adapted them to suit the audience, the occasion, the context, or the carrier. ${ }^{14}$

12 For this translation of the obscure $\mathbf{a}-\mathbf{e} \mathbf{i}_{3}$-mi-e $\mathbf{e}_{3}$, see Zólyomi 2019a. This translation gives further support to the assumption that $\mathbf{e g}_{2}$ in question was in fact not a canal but a boundary bund; see also footnote 10 above.

13 Selz $(1995,119)$ translates NBC 2501 3:34-37 as "Mit Fürstlichkeit gegründet von? Enlil, von? Enki (und) von? Ninhursag(a)". If he is right to assume that the divine names are part of the proper name, then the Louvre version would represent a truncated form of the full name. Alternatively, one may assume that the Namnunda-kinara had different parts identified by the pedestals erected on it (as described in 2:1118 of the Louvre and 2:28-3:2 of the Yale manuscript). Then the composer of the Yale version may have given a more detailed description about the destruction.

14 These examples of variations demonstrate that composers of the Early Dynastic royal inscriptions used the same techniques to manipulate the texts according to their function and use as the scribes who wrote the Assyrian royal inscriptions of the 1st millennium; see Cancik-Kirschbaum 2007. 


\section{Transliteration and translation}

\section{column 1}
1. den-lil ${ }_{\mathrm{x}}\left(\mathrm{E}_{2}\right)$
2. lugal kur-kur-ra
3. rab-ba dinir-dinir-[re $\left.{ }_{2}\right]-$-ne'-ke $_{4}$
4. [inim] rgi-[na-ne ${ }_{2}$-ta]

\section{a gap of 13 lines}

$$
\begin{aligned}
& \text { 1. } \quad\left[\text { na-ru }_{2}\right. \text {-a]-be }
\end{aligned}
$$

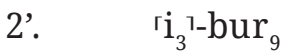

$$
\begin{aligned}
& \text { 3. } \quad \text { redin' lagaški }- \text { še }_{3} \\
& \text { 4. } \quad \mathrm{i}_{3}-\operatorname{kur}_{\mathrm{x}}(\mathrm{DU}) \\
& \text { 5'. dnin-nir }{ }_{2} \text {-su } \\
& \text { 6'. ur-san den-lil }{ }_{\mathrm{x}}\left(\mathrm{E}_{2}\right)-\mathrm{la}_{2}-\mathrm{ke}_{4} \\
& \text { 7'. inim si sa } \text { sene }_{2} \text {-ta } \\
& \text { 8'. ummaki-da }
\end{aligned}
$$

\section{column 2}

$$
\begin{aligned}
& \text { 1. dam-ḩa-ra } \\
& \text { 2. e-da-ak } \\
& \text { 3. inim }{ }^{\mathrm{d} e n-l i l_{\mathrm{x}}}\left(\mathrm{E}_{2}\right)-\mathrm{la}_{2} \text {-ta } \\
& \text { 4. } \quad \text { sa-šuš-gal bi }{ }_{2} \text {-šuš }
\end{aligned}
$$

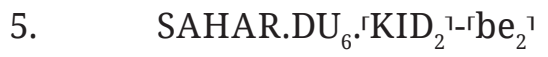

$$
\begin{aligned}
& \text { 6. edin-na ki ba-ni-гus }{ }_{2}{ }^{1-u s_{2}}
\end{aligned}
$$

\section{a gap of approximately 19 lines}

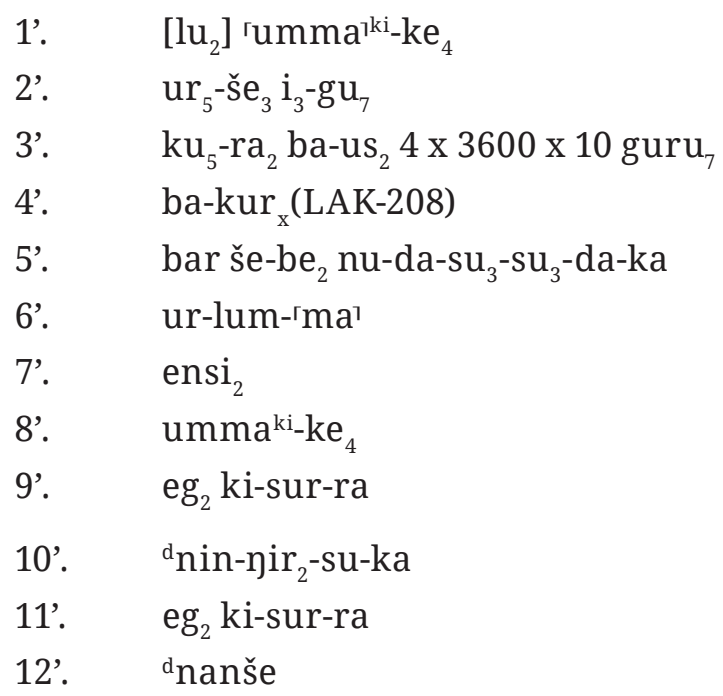

${ }^{1: 1-4}$ By his firm command, Enlil, the king of all lands, the father of all gods, ........

1:1'-4'.... having torn the stele out he (= Nita) entered towards the plain of Lagaš.

1:5'-2:6y (Enlil's) just command, Ninnirsu, Enlil's warrior, did battle with Umma. By Enlil's command, he cast on it the great battle-net, and heaped up burial mounds for it on the plain.
2:1'-4'The leader of Umma took ...... as interest bearing loan. It yielded interest and accumulated to 144,000 guru.

2:5'-3:4 As this (amount) of barley could not be repaid, Ur-Luma, ruler of Umma, destroyed Ninnirsu's boundary levee and Nanše's boundary levee with water. He set fire to their stelae and tore each of them out. 


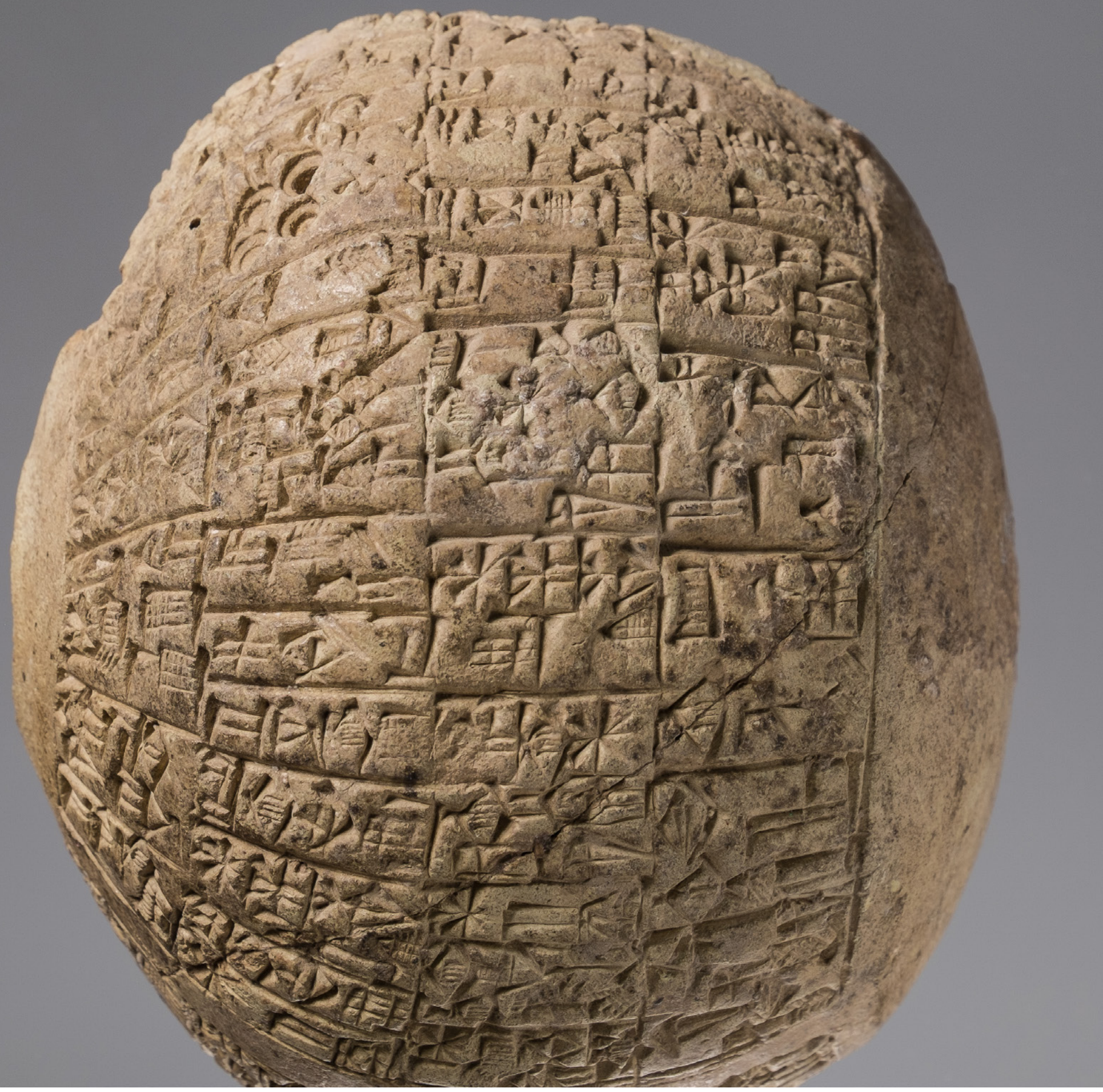

FIGURE 3. The middle part of cols. 2-4. Photo courtesy of the Sulaymaniyah Museum. 


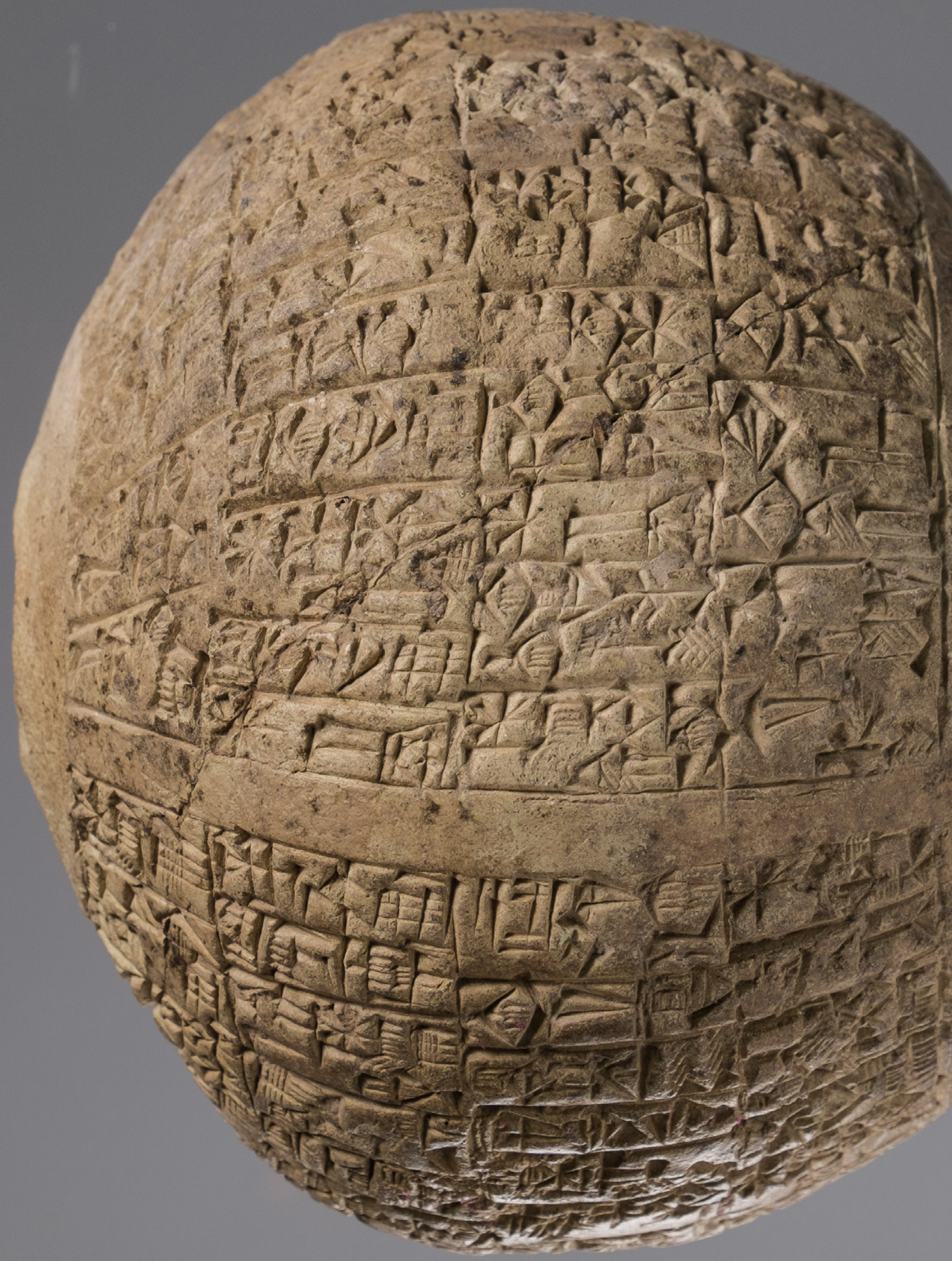

FIGURE 4. The beginning and end of cols. 2-4. Photo courtesy of the Sulaymaniyah Museum. 


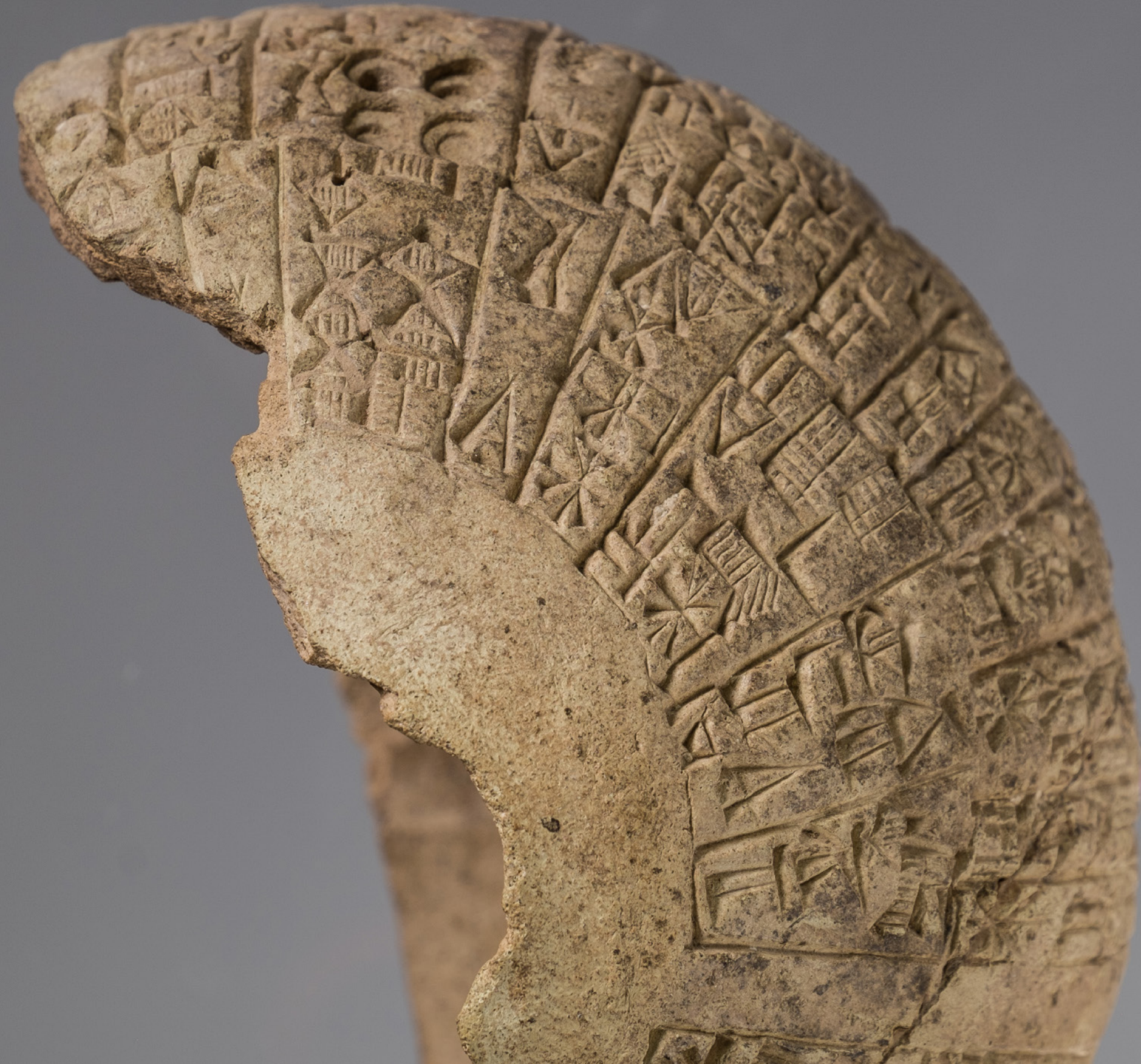

FIGURE 5. Part of the upper part of T.3860 with the end of col. 1. Photo courtesy of the Sulaymaniyah Museum. 


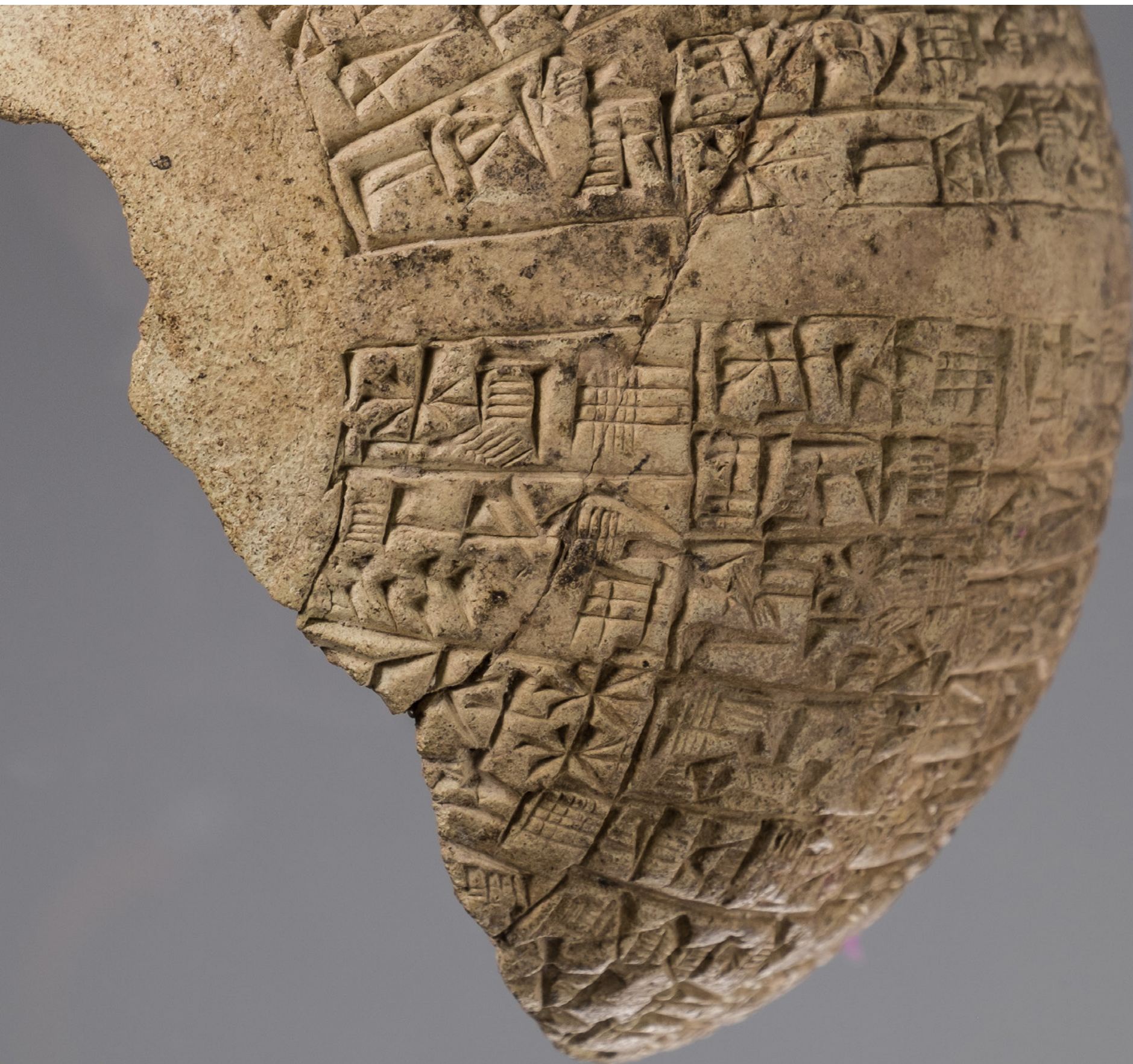

FIGURE 6 (ABOVE). Part of the upper part of T.3860 with the beginning of col. 1. Photo courtesy of the Sulaymaniyah Museum.

FIGURE 7 (NEXT PAGES, LEFT). Bottom of T.3860. Photo courtesy of the Sulaymaniyah Museum.

FIGURE 8 (NEXT PAGES, RIGHT). Inside of T.3860. Photo courtesy of the Sulaymaniyah Museum. 


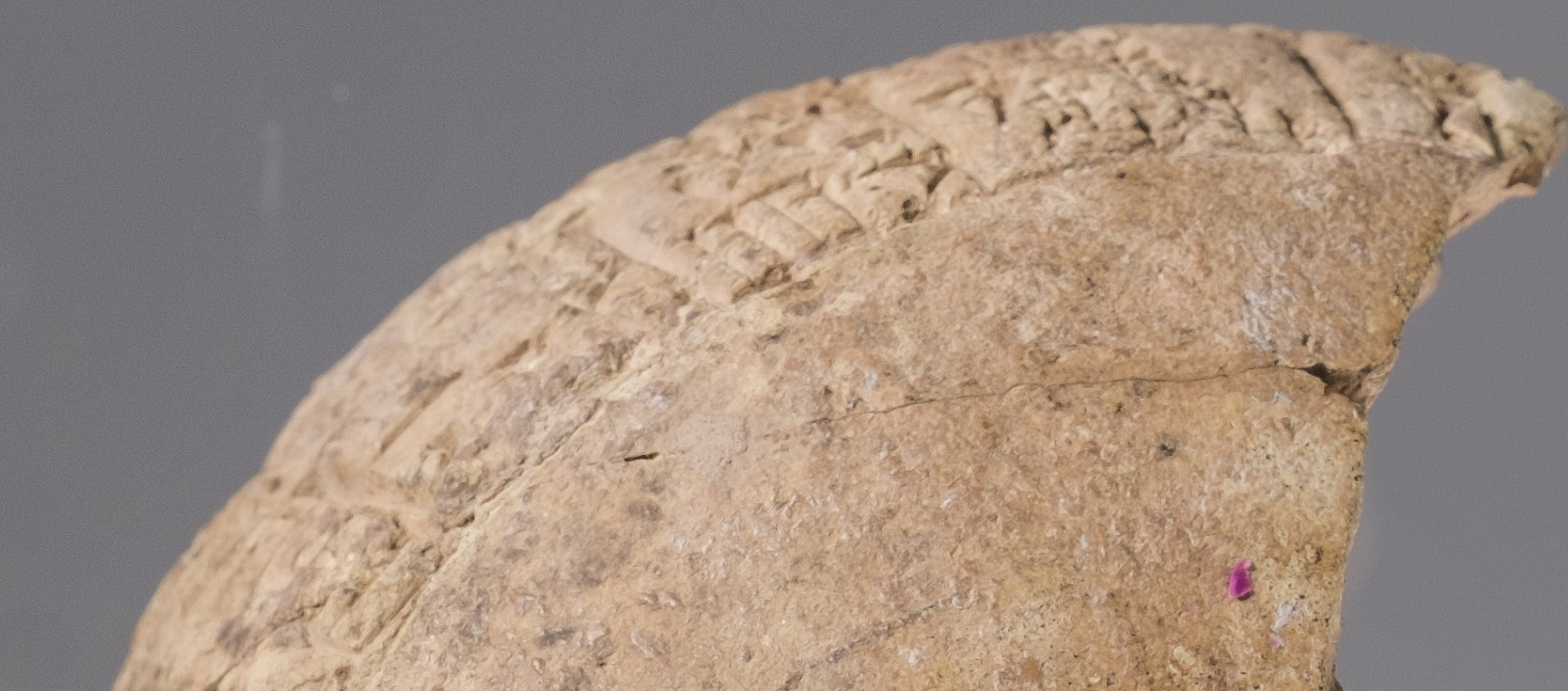




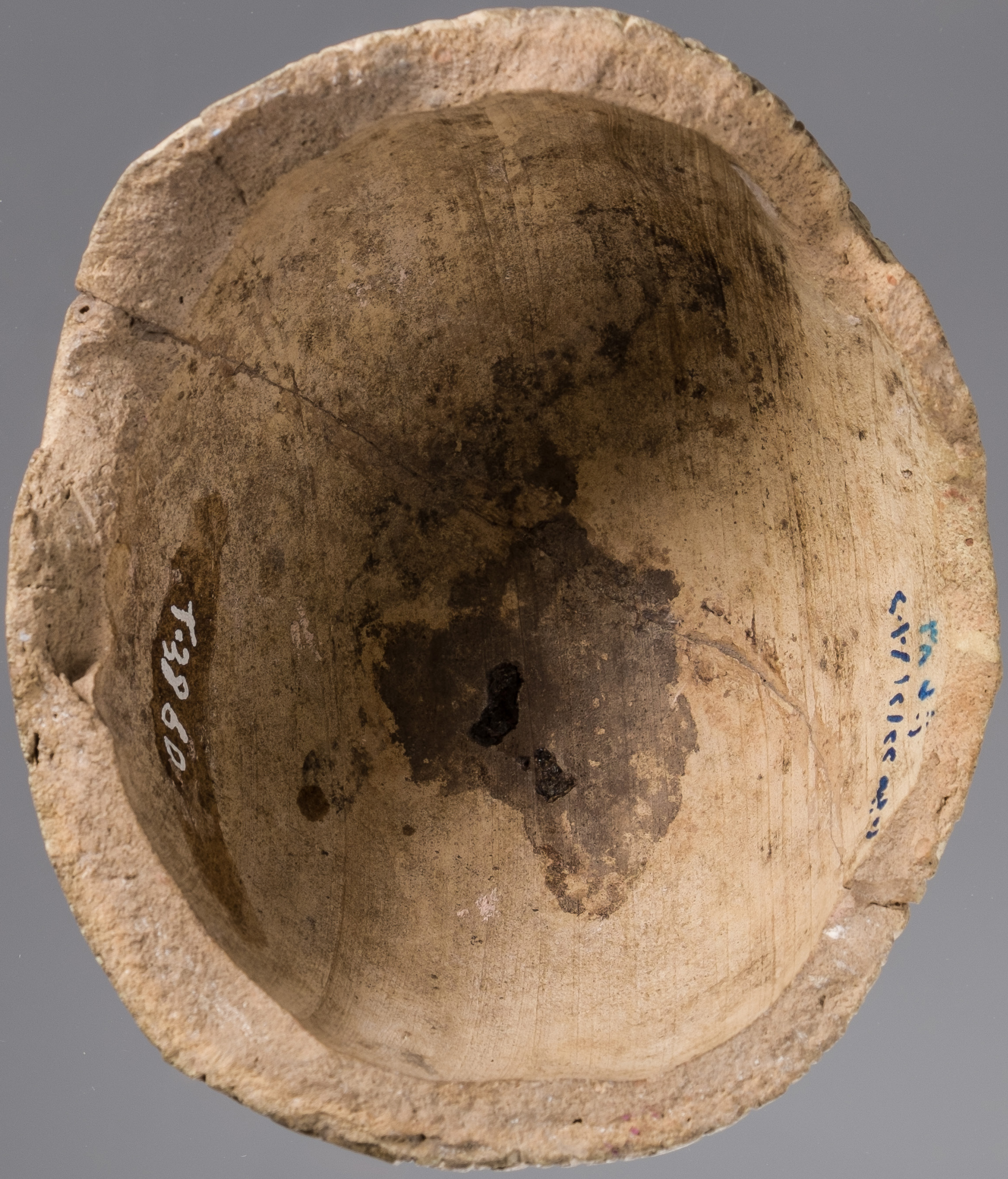




\section{column 3}
1. a-e $\mathrm{i}_{3}-\mathrm{mi}^{-\mathrm{e}_{3}}$
2. $\quad$ na-ru $\mathrm{r}_{2}-\mathrm{a}-\mathrm{be} \mathrm{e}_{2}$
3. izi ba-šum
4. $\quad \mathrm{i}_{3}$-bur $_{9}-$-bur $_{9}$
5. $\quad \mathrm{il}_{2}-\mathrm{le}$
6. nam-ensi ${ }_{2}$
7. ummaki-a
8. šu e-ma-rtir

\section{a gap of approximately 20 lines}

0' [nam-nun-da-ki-nar-ra]

1'. $\quad \operatorname{rur}_{2}{ }^{1}$-be ${ }_{2}$ na $_{4}$ mu-ni-du

2'. $\quad$ eg $_{2}-\mathrm{be}_{2}$

3'. id2idigna-ta

4'. $\quad$ id $_{2}$-nun-še ${ }_{3}$

5'. e-ak

6. lugal ki an-na-гап ${ }_{2}-$-na $_{2}{ }^{1}-$ ne $_{2}$

7. $\quad{ }^{\mathrm{d}}$ nin-nir ${ }_{2}$-su-ra

8. nin ki an-na-an ${ }_{2}-$-na $_{2}-$-ne $_{2}$

9'. dnanše

10'. ki-be ${ }_{2}$ mu-na-gi

11'. dinir en-mete-na-ka

\section{column 4}

$\begin{array}{ll}\text { 1. } & \text { dšul-MUŠxPA } \\ \text { 2. } & \text { nam-til } \\ \text { 3. } & \text { en-mete-na-ka-še } \\ \text { 4. } & \text { ud ul-la-še } \\ \text { 5. } & { }^{\mathrm{d}} \text { nin-nir } \\ 2 & \text {-su-ra } \\ \text { 6. } & { }^{\mathrm{d}} \text { nanše } \\ \text { 7. } & \text { 'he }_{2} \text {-na'-ši-rgub }\end{array}$

a gap of 13 lines

\begin{tabular}{|c|c|}
\hline 1’. & {$\left[\mathrm{sa} \mathrm{šu}_{4}\right.$ gal]-「ne ${ }_{2}^{\top}$} \\
\hline 2'. & $\mathrm{u}_{3}-\mathrm{ni}$-šu $\mathrm{u}_{4}$ \\
\hline 3'. & šu mah giri ${ }_{3}$ mah-ne $_{2}$ \\
\hline 4'. & an-ta he $e_{2}-\eta a_{2}-\eta a_{2}$ \\
\hline 5'. & nam-lu ${ }_{2}-l u_{7}$ iri-na \\
\hline 6'. & šu $u_{3}$-na-zig \\
\hline 7’. & 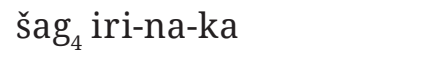 \\
\hline $8^{\prime}$. & ha-ne ${ }_{2}-$ gaz-ze $_{\mathrm{x}}\left(\mathrm{AB}_{2} \cdot \mathrm{S̆}_{3} \cdot \mathrm{GI}\right)$ \\
\hline
\end{tabular}

3:5-8Il claimed the rulership of Umma for himself.

3:0'-10'He built the substructure of [the Namnunda-kinara] of stone. He constructed its dyke from the Tigris to the Id-nun. For Ninnirsu, his master who loves him, and for Nanše, the lady who loves him, he restored it.

3:11'-4:7May En-metena’s personal god,

Šul-MUŠxPA, intercede forever for En-metena's well-being with Ninnirsu and Nanše!

4:1'-4'Having cast on him his great battle-net, may [Ninnirsu] pound him down with his majestic hands, tread on him with his majestic feet!

4:5'-8'Having revolted against him in his city, may the people kill him in the middle of his city! 


\section{Commentary}

1:2': Frayne states that "[a]nother possibility is to read the verb as padr = kasāpu(m) "to break into bits." ${ }^{\prime 15}$ Note that this reading is implausible because of the prefix-chain of the verbal form (cf. also l. 3:4). A reading like pad would require e-pad because of the Old Sumerian vowel harmony. ${ }^{16}$

2:3': This line is written in two lines in the Louvre cone (2:24-25) and the Yale jar (3:8-9). In the Sulaymaniyah manuscript the GAL sign is missing, which renders the number here 60 times less: 144,000; compared to 8,640,000 in the Louvre cone and the Yale jar.

3:4 and 5: Between these two lines, the Louvre cone (2:39-3:33) and the Yale jar (3:23-4:23) contain 37 additional lines, which are not included in the Sulaymaniyah version of En-metena 1:

"He destroyed the pedestals erected for the gods that were set up at Namnunda-kinara. He hired foreigners and crossed Ninnirsu's boundary levee. In the Ugiga field, the field of Ninnirsu, Enana-tum, ruler of Lagaš, fought with him. En-metena, the beloved child of En-ana-tum, defeated him. Ur-Luma escaped, (En-metena) forced him back to Umma. 60 teams of his donkeys were abandoned on the bank of the Luma-nirnunta canal. The bones of their personnel were left strewn all around the plain. He piled up their burial mounds in five places. Then Il, who was the temple administrator of Zabalam, marched from Nirsu until Umma in retreat."

This long omission suggests that the Sulaymaniyah ms. may definitely be considered an abbreviated version, since without the information contained in these 37 lines the clause about Il in the Sulaymaniyah version (3:5-8) makes little sense.

3:1': The Louvre cone (5:13) and the Yale jar (5:35) write this line as $\mathbf{u r}_{2}$-be $\mathbf{b}_{2} \mathbf{n} \mathbf{a}_{4}$-a mu-na-ni-du . The missing line before 3:1', referred to as 3:0' above, may almost certainly be restored as namnun-da-ki-nar-ra.

On the Louvre cone and the Yale jar, the lines corresponding to 3:2'-5' precede the lines corresponding to 3:0'-1'. On these manuscripts the passage sounds like this:

"(En-metena) constructed the dyke from the Tigris to the Id-nun. He built the substructure of the Namnunda-kinara of stone for him. For Ninnirsu, his master who loves him, and for Nanše, the lady who loves him, he restored it."

In this version of the passage the last clause is understood usually to refer to the restoration of the Namnunda-kinara, as the paraphrase of Bauer and the translation of Cooper below show:

"Die Namnundakigara genannte Stätte stellt er wieder her und versieht sie mit einem steinernen Fundament”. ${ }^{17}$

"He built the foundations of the Namnundakigara for him (Ningirsu) out of stone, restoring for the master who loves him, Ningirsu, and for the mistress who loves him, Nanshe."18

If the Sulaymaniyah version is considered a genuine variation and not one due to erroneous copying, then this version may imply that the dyke from the Tigris to the Id-nun and the Namnunda-kinara were the same, i.e. the latter was the name of the former.

\footnotetext{
15 Frayne 2007, 194.

16 Cf. Zólyomi 2017, 29-31.

17 Bauer 1998, 473.

18 Cooper 1986, 55.
} 
As regards the function of Namnunda-kinara's strengthening, see Pemberton et al. mentioning Willcocks who "refers to attempts to reinforce the slopes of the dykes against the action of waves with masonry or by growing grass" 19 in Egypt.

3:2'-3': These two lines are written in one line in the Louvre cone (5:9) and the Yale jar (5:32).

3:11'-4:7: These lines of the Sulaymaniyah manuscript correspond to a twelve lines longer passage in the Louvre cone (5:19-6:8) and the Yale jar (5:42-6:8), as the comparison between the versions below demonstrate: ${ }^{20}$

\section{Sulaymaniyah ms.}

3:11 $\quad$ dinir en-mete-na-ka

\section{En-metena $1^{21}$}

\begin{tabular}{|c|c|}
\hline en-mete-na & $5: 19$ \\
\hline ensi $_{2}$ & $5: 20$ \\
\hline lagaški & $5: 21$ \\
\hline nidru šum ${ }_{2}$-ma & $5: 22$ \\
\hline den-lil ${ }_{x}\left(E_{2}\right)-l_{2}$ & $5: 23$ \\
\hline neštug $_{2}$ šum $_{2}$-ma & $5: 24$ \\
\hline${ }^{\mathrm{d}}$ en-ki-ka & $5: 25$ \\
\hline šag $_{4} \mathrm{pad}_{3}$-da & $5: 26$ \\
\hline dnanše & $5: 27$ \\
\hline ensi $i_{2}$-gal & $5: 28$ \\
\hline dnin-nir ${ }_{2}$-su-ka & $5: 29$ \\
\hline $\mathrm{lu}_{2}$ inim dinir-re $\mathrm{e}_{2}$-ne dab $\mathrm{da}_{5}$-ba & $5: 30$ \\
\hline dinir-ra-ne $_{2}$ & $6: 1$ \\
\hline dšul-MUŠxPA & $6: 2$ \\
\hline nam-til ${ }_{3}$ & $6: 3$ \\
\hline en-mete-na-ka-še ${ }_{3}$ & $6: 4$ \\
\hline ud ul-la-še ${ }_{3}$ & $6: 5$ \\
\hline dnin-nir ${ }_{2}$-su-ra & 6:6 \\
\hline dnanše & $6: 7$ \\
\hline$h_{2} e_{2}$-na-ši-gub & $6: 8$ \\
\hline
\end{tabular}

In the long version of the Louvre cone and the Yale jar, the grammatical subject of the finite verb (he $_{2}$-na-ši-gub), the god Šul-MUŠxPA, is expressed with a complex construction. It is an appositive construction consisting of two parts:

i) a left-dislocated (= anticipatory) genitive construction. The possessum of this genitive construction is the word "(personal) god" (dinir) in 6:1. The left-dislocated possessor is En-metena, whose name in 5:19 is followed by six epithets in 5:20-30;

ii) the name of En-metena's personal god (dšul-MUŠxPA) in 6:2.

19 Pemberton et al. 1988, 215. The reference is to Willcocks 1899, 116-118.

20 On this passage, see Zólyomi 2019b.

21 The composite text is based on AO 3004, NBC 2501, and VAT 16438; it follows the line numbering of the Louvre manuscript. 
The scribe who wrote the Sulaymaniyah manuscript abridged the text i) by omitting parts of the text: he left out all six epithets of En-metena; and ii) by replacing a complex structure by a simpler one: he substituted the left-dislocated genitive construction with a simple, not left-dislocated genitive construction: dinir en-mete-na-ka "En-metena’s personal god".

4:5'-8': Cooper translated these lines as "May the people of his own city, after rising up against him, kill him there within his city!”, ${ }^{22}$ This translation would, however, require nam-lu ${ }_{2}-\mathbf{l u}_{7}$ irina-ke ${ }_{4}$ in 4:5'. The phrase in question may be interpreted to function either as the subject of the compound verb šu - zig "to revolt (lit. to raise the hand)" in 4:6'; or as the subject of the verb gaz "to kill" in 4:8'. ${ }^{23}$ In either case it should be in the ergative. The wordform iri-na may therefore not be the possessor nam-lu $\mathbf{u}_{2}-\mathbf{l} \mathbf{u}_{7}$, only a place adverbial in the locative.

\section{References}

AL-AsADI, Y. 2015: Vultures Obelisk: A Model for Integration Narrative between the Art Work and of the Sumerian Writings. Magazine of Historical Studies and Archaeology 47, 52-122 (in Arabic).

Almamori, H. O. 2014: Gišša (Umm al-Aqarib), Umma (Jokha), and Lagaš in the Early Dynastic III Period. Al-Rāfidān 35, 1-37.

BALKE, T. 2006: Das sumerische Dimensionalkasussystem. (Alter Orient und Altest Testament 331) Münster.

BAUER, J. 1998: Der vorsargonische Abschnitt der mesopotamischen Geschichte. In: BAUER, J. ET AL.: Mesopotamien. Späturuk-Zeit und Frühdynastische Zeit. (Orbis Biblicus et Orientalis 160, I) Fribourg - Göttingen, 431-585.

Cancik-Kirschbaum, E. 2007: Text - Situation - Format. Die materielle Gegenwart des Textes. In: Morenz, L. - Scновсн, S. (eds.): Was ist ein Text? Alttestamentliche, ägyptologische und altorientalische Pespektiven. (Beihefte zur Zeitschrift für die alttestamentliche Wissenschaft 362) Berlin - New York, 155-168.

Cooper, J. S. 1986: Sumerian and Akkadian Royal Inscriptions, Vol. I: Presargonic Inscriptions. (The American Oriental Society. Translations Series 1) New Haven.

Frayne, D. 2007: Presargonic Period (2700-2350 BC). (The Royal Inscriptions of Mesopotamia. Early Periods 1) Toronto. https://doi.org/10.3138/9781442688865

Jagersma, A. H. 2010: A descriptive grammar of Sumerian. PhD Dissertation, Universiteit Leiden.

MARZAHn, J. 1997: Entemena in Uruk. Baghdader Mitteilungen 28, 87-96.

Pemberton, W. - Postgate, J. N. - Smyth, R. F. 1988: Canals and bunds, ancient and modern. Bulletin on Sumerian Agriculture 4, 207-221.

SELZ, G. 1995: Untersuchungen zur Götterwelt des altsumerischen Stadtstaates von Lagaš. (Occasional Publications of the Samuel Noah Kramer Fund 13) Philadelphia.

Steible, H. - Behrens, H. 1982: Die altsumerischen Bau- und Weihinschriften, I-II. (Freiburger Altorientalische Studien 5) Stuttgart.

WiLLcocks, W. 1899, Egyptian Irrigation. 2nd edition. London - New York.

ZóLYomi, G. 2017: An Introduction to the Grammar of Sumerian. With the collaboration of Sz. Jáka-Sövegjártó and M. Hagymássy. Budapest.

ZóLyomi, G. 2019a: On the meaning of a-e $\mathrm{i}_{3}-\mathrm{mi}_{-} \mathrm{e}_{3}$ in En-metena 1. Nouvelles Assyriologiques Brèves et Utilitaires, 2-5 (No. 2)

ZóLYomi, G. 2019b: Native-speaker intuitions about genitive constructions in Sumerian. Altorientalische Forschungen 46, 301-311. https://doi.org/10.1515/aofo-2019-0019

22 Cooper 1986, 56. Frayne's $(2007,199)$ translation differs only in changing "his city” to "his (own) city” in the last clause.

23 Note that Steible and Behrens (1982, I, 245) also consider the phrase a genitive construction: "die Bevölkerung seiner Stadt”. 



\section{Cuneiform Luwian =ku(wa): form and meaning}

\section{Zsolt Simon*}

* - Institut für Assyriologie und Hethitologie, Ludwig-Maximilians-Universität München. Email: zsltsimon@gmail.com

Abstract: This paper provides a new attempt at defining the form and meaning of an unclear Luwian particle.

Keywords: Cuneiform Luwian, Luwian syntax, Luwian sentence initial particles

Cite as Simon, Zs. 2020: Cuneiform Luwian =ku(wa): form and meaning. Hungarian Assyriological Review 1, 39-42. https://doi.org/10.52093/hara-202001-00003-000

(C) (1) This is an open access article distributed under the terms of the Creative Commons Attribution License, which permits unrestricted use, distribution, and reproduction in any medium, provided the original author and source are credited.

Although the Cuneiform Luwian particle $=k u(w a)$ is relatively well attested considering the size of the Cuneiform Luwian corpus, its precise meaning and its precise form remain elusive. This brief note provides a new proposal based on the re-examination of its attestations.

Practically all instances of this particle appear in the sequence spelled -ku-wa-. ${ }^{1}$ The only possible exception is in KUB 35.133 ii 3', where -ku- is followed by -ni-in ku-i-pa-ku-ni-ia-aš: ${ }^{2}$ although the sequence preceding - $k u$ - can regularly be analysed as $k u i=p a=$ (i.e. the first word of a sentence with the attached adversative particle), this does not apply to the sequence following -ku-, since the resulting " $=n i=$ " is never attested. ${ }^{3}$ The same applies to the proposal of I. Yakubovich, who would view this "=ni=" as a prohibitive particle: ${ }^{4}$ such a particle is otherwise not attested in the extant Luwian corpus. Although Melchert claims that the "alternatives are also problematic", ${ }^{5}$ this is not entirely the case: the context is fragmentary, the words preceding ku-i-pa-ku-ni-ia-aš are missing and it is followed only by $k u-i$ a-[...], ${ }^{6}$ in other words, one cannot exclude the possibility that it is not even the first word of a sentence with the particle chain. Moreover, even if it represents the first word, one cannot exclude an analysis kuipakuni(ya)=aš either, i.e. that only $=a s ̌$ is a particle. ${ }^{7}$ All in all, prudence dictates not to include this passage in the list of attestations of $=k u(w a)$.

1 For the more than two dozen attestations see Melchert 1993, 105. Note that the photo of KBo 13.260 ii 6 clearly shows a KU and not a MA, contra Starke 1985, 260; Melchert 1993, 105; and Torri - Barsacchi 2018, 293, which is also required by the context. Although Melchert includes KUB 35.103 ii 8' as a fragmentary form of this particle, the sign is no longer visible on the photo of the Konkordanz der hethitischen Keilschrifttafeln (hethiter.net/: PhotArch N09968) (even though the hand copy shows minor traces and its presence is probable in view of the parallel passages, cf. Starke 1985, 222). On KUB 35.133 ii 3' see the main text.

2 Melchert 1993, 105 includes this attestation with a double question mark.

3 Also Melchert 1993, 157 emphasizes that this analysis is “very dubious”.

4 ACLT s.v. (last accessed: 22 February 2019).

5 Melchert 1993, 157.

6 Starke 1985, 279.

7 As I. Yakubovich (per litt.) informs me, he would now read this sign sequence as $k u-i-p a-k u-i^{\prime}-i a-a s ̌$, which would eliminate the entire problem. 
Accordingly, the first question is if the form of the particle is $=k u w a^{8}$ or only $=k u$ (and then $=w a$ would be identical to the quotative particle). ${ }^{9}$ Kloekhorst claims that although it is tempting to analyse the word as =kuwa, this is "impossible" due to the parallel particle chains of an$n i \check{s}=k u=w a=t i$... tātiš $=p a=w a=t i=$ in KUB 35.102 ii $15-16 .{ }^{10}$ However, due to the possible and phonologically completely regular contraction from $=k u w a$ into $=k u$ neither the above discussed alleged form -ku-ni- nor Kloekhorst's example is decisive (Carruba also entertains the possibility of haplology, ${ }^{11}$ which, however, can be neither proven nor refuted). Thus there are only two ways to solve this issue: the first would be to find an attestation with the spelling -ku-wa-wa-. This is, however, lacking so far. The second would be to find a case in which - wa- in -ku-wa- cannot be interpreted as a quotative particle. Although Melchert claims that this -wa-is the quotative particle in all clear cases, ${ }^{12}$ this is contradicted by KUB $35.103 \mathrm{rev} .1-5:{ }^{13}$ this is a repetition of some acts in the same tablet (KUB 35.103 ii 13'-14', iii 4-5, for the texts see below), but, unlike in these passages, there is no quotative particle (note that $=w a=$ in line 5 is a restoration only). However, it starts with -ku-wa-: [i-ia]-an-du-ku-wa (line 1). Thus - wa- cannot be interpreted here as a quotative particle, which shows that the (full) form of this particle is =kuwa.

As far as the meaning is concerned, setting aside outdated views ${ }^{14}$ and those many scholars who do not provide any meaning ${ }^{15}$, the remaining proposals are generally similar, but differ in their details: Melchert saw in it a clause connecting particle with a meaning 'also, furthermore' vel sim. ${ }^{16}$ Kloekhorst agreed with this, but pointed out that its meaning is in fact unclear and a translation 'and' is "of course quite possible" (thus defining it as 'and (?), furthermore (?)'). ${ }^{17}$ Boley suggested that a meaning 'on the other hand' is not impossible, ${ }^{18}$ similarly already Carruba, who compared the particle combination ...ku ...pa with Greek $\mu \varepsilon \dot{v} v . . \delta \varepsilon$ 'on the one hand ..., on the other

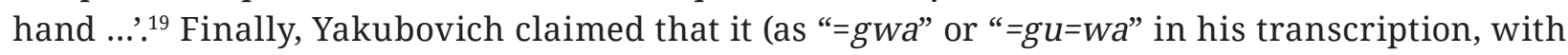
question mark) "alternates" with the quotative particle $=w a,{ }^{20}$ but this is excluded by KUB 35.103 rev. 1-5 discussed above, which shows that we are dealing with two different particles.

Unfortunately, most of the attestations originate from fragmentary contexts (which also implies that some of the attestations may not even belong here), but some of them can be helpful,

8 As per Laroche 1959, 58; Tischler 1977-1983, 599 (but cf. below); Puhvel 1997, 204; Ünal 2016, 92.

$9 \quad$ As per Melchert 1993, 105; Tischler 2008, 97; 2016, 183; Hajnal - Zipser 2017, 312; cf. already Carruba 1969, 72 with question mark.

10 Kloekhorst 2008, 484.

11 Carruba 1969, 72.

12 Melchert 1993, 205.

13 For the text see Starke 1985, 223.

14 For references see Laroche 1959, 58 and Carruba 1969, 72.

15 Laroche 1959, 58; Tischler 1977-1983, 599; 2008, 97; 2016, 183; Puhvel 1997, 204 (“problematic"); Ünal 2016, 962; and although treated as a separate particle, it was left untranslated also in Kloekhorst 2008, 936 (but cf. the main text); Francia 2014, 11; and Giusfredi 2014, 309.

16 Melchert 1993, 105.

17 Kloekhorst 2008, 483-484.

18 Boley 2004, 100-101.

19 Carruba 1969, 72-73. He added that the assumption of a derivative of Proto-Indo-European * $k^{w} e^{w}$ 'and' (the alleged etymon of $=k u(w a)$ ) is more economic than the assumption of a new particle of unknown function. Needless to say, etymological considerations shall play no role in the synchronic identification of the grammatical function of a particle.

20 Yakubovich 2015, §6.6. Also in his ACLT s.v. (last accessed 22 February 2019) he gives the translation 'quotative particle'. As he informed me (per litt.), he has since given up this description. 
especially the following passage (KUB 35.103 ii 11'-16', ${ }^{21}$ own translation):

${ }^{\left(11^{\prime}\right)}[i-u ́-u] n-n i-w a{ }^{(\ldots . .)}{ }^{\left(12^{\prime}\right)}(\ldots)$ a-a-pa-an ḩi-iz-za-ú-un-[ni] §

'We proceed and hand over that (...).'22

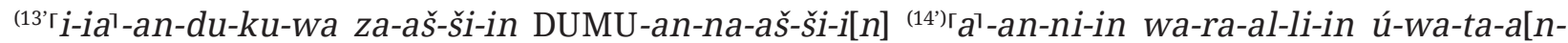
$d u]$

'In turn, they shall proceed and bring this child's own mother.'

${ }^{\left(15^{\prime}\right)}[a] n-n i-i s ̌-k u-w a-t i$ pár-na-an-za ma-ad-du-ú-w[a-ti] ${ }^{\left(16^{\prime}\right)[p] a-a p-p a ́ r-k u-w a-a t-t i ~ t a-a-t i-i s ̌-p a-w a-~}$ ti-ia-[ta]

'The mother, in turn, will clean the house with wine, but the father [...]'

There are three consecutive acts (11'-12'), (13'-14'), and (15'-16'), but the subjects are different in all cases: we do something, they should do something, and finally the mother will do something. Accordingly, the conjunction should refer not only to the additionality of the acts, but also to their slightly adversative nature, i.e. that the new subjects will do something different. The proposed meanings 'and, also, furthermore' refer to the additionality of the new information, but they do not refer to its adversative nature. The suggestion 'on the other hand' reflects this adversativity, but not the additionality. The most precise reading of this passage can be reached by the combination of these two nuances, i.e. an adversative-successive particle as 'in turn'.

The situation is similar in the following passage from the same text (KUB 35.103 iii 1-623):

${ }^{(1)}[p] a-w a$ i-ia-an-du (...) ${ }^{(3)}$ ra'-pa-an hi-iz-za-in-du §

'They shall proceed and hand over that (...).'

${ }^{(4)} z a-a m-p a-k u-w a$ DUMU-ni-in wa-al-li-in-du ${ }^{(5)}$ ša-an-na-i-in-du pa-wa-an-tar a-an-ni ${ }^{(6)}[t] i-i-t a-n i$ $d u-u ́-w a-a n-d u$

'This child, in turn, they shall lift, turn down, and they shall put him on the breast of the mother.'

Here again we are dealing with two consecutive acts, but in this case the subjects are identical. What is not identical is the object of their activity. Thus, the above described meaning 'in turn' fits very well here too, as it can refer to the different objects of these acts ("that" and "this child").

From all this follows also that =kuwa is not a clause linking particle, which is clearly supported by its attestations in combination with =pa 'but' (i.e. $x=p a=k u w a(=)$ ), e.g. KUB 35.79 iv 10.12; KUB 35.103 iii 4; KBo 29.25 iii $14 .^{24}$

\section{Acknowledgements}

This paper was written in the framework of the Digital Philological-Etymological Dictionary of the Minor Ancient Anatolian Corpus Languages (https://www.ediana.gwi.uni-muenchen.de/)

21 Starke 1985, 222 with refs.

22 Here and in the following sentences the verb $i$ - 'to go' is translated as the auxiliary verb of the so-called serial or phrasal construction. Three features of the characteristics of this construction can be crosschecked in these sentences: full agreement of $i$ - with the main verb of the same clause, clause-initial position, omission of the clitic subject of $i$ - with a transitive main verb (cf. the overview in Hoffner Melchert 2008: 324-325 with refs.). All of them apply here, thus these phrases can be characterized as real serial / phrasal constructions, contra van den Hout 2010, 202.

23 Starke 1985, 222 with refs.

24 Note that this combination demonstrates that the description of Hajnal - Zipser 2017, 312, who assigned $=k u$ to the second slot of the Luwian sentence initial particle chain together with =ha and $=p a$, is false. 
financed by the DFG. I am grateful to Frances Martin for correcting my English.

\section{References}

ACLT = YaKubovich, I.: Annotated Corpus of Luwian Texts. http://web-corpora.net/LuwianCorpus

Boley, J. 2004: The Storyteller's Art in Old Hittite. The Use of Sentence Connectives and Discourse Particles. Res Antiquae 1, 67-110.

CArruba, O. 1969: Die satzeinleitenden Partikeln in den indogermanischen Sprachen Anatoliens. (Incunabula Graeca 32) Roma.

Francia, R. 2014: Gli scongiuri e pronunciamenti magici in luvio: tentativi di analisi stilistica. Scienze dell'Antichità 20, 3-14.

Giusfredi, F. 2014: The Cuneiform Luwian Local Particles and the Obscure Particle -(V)r. In: TARACHA, P. (ed.): Proceedings of the Eighth International Congress of Hittitology. Warsaw, 5-9 September 2011. Warsaw, 308-316.

HAJNAL, I. - Zipser, K. 2017: Die Pronominal- und Partikelkette in den altanatolischen Sprachen. Ererbt oder einzelsprachlich? Indogermanische Forschungen 122, 309-339. https://doi.org/10.1515/if-2017-0016

Hoffner, H. A. - Melchert, H. C. 2008: A Grammar of the Hittite Language 1. Reference Grammar. (Languages of the Ancient Near East 1) Winona Lake, Indiana.

VAN DEN Hout, TH. 2010: Studies in the Hittite Phraseological Construction II. Its Origin. Hethitica 16, 191204.

Kloekhorst, A. 2008: Etymological Dictionary of the Hittite Inherited Lexicon. (Leiden Indo-European Etymological Dictionary Series 5) Leiden - Boston.

LARoche, E. 1959: Dictionnaire de la langue louvite. (Bibliothèque archéologique et historique de l’Institut français d'archéologie d'Istanbul 6) Paris.

Melchert, H. C. 1993: Cuneiform Luvian Lexicon. (Lexica anatolica 2) Chapel Hill.

Punvel, J. 1997: Hittite Etymological Dictionary 4. Words beginning with K. Berlin - New York. https://doi. org/10.1515/9783110801231

Starke, F. 1985: Die keilschrift-luwischen Texte in Umschrift. (Studien zu den Boğazköy-Texten 30) Wiesbaden.

TIschleR, J. 1977-1983: Hethitisches etymologisches Glossar I. A-K. (Innsbrucker Beiträge zur Sprachwissenschaft 20) Innsbruck.

Tischler, J. 2008²: Hethitisches Handwörterbuch. Mit dem Wortschatz der Nachbarsprachen. (Innsbrucker Beiträge zur Sprachwissenschaft 102) Innsbruck.

TISChleR, J. 2016: Vocabulaire hittite y compris louvite, palaïte, akkadien et sumérien. (Lettres orientales et classiques 20) Leuven - Paris - Bristol, CT.

Torri, G. - Barsacchi, F. G. 2018: Hethitische Texte in Transkription. KBo 13. (Dresdner Beiträge zur Hethitologie 51) Wiesbaden.

ÜNAL, A. 2016: Hititçe-Türkçe Türkçe-Hititçe Büyük Sözlük. Hattice, Hurrice, Hiyeroglif Luvicesi, Çivi Yazısı Luvicesi ve Palaca Sözcük Listeleriyle Birlikte. Ankara.

Yakubovich, I. 2015: The Luwian Language. Oxford Handbooks Online. https://doi.org/10.1093/oxfordhb/9780199935345.013.18 


\title{
The property of the city, the property of the king? A new fragment of YOS 12, 321
}

\author{
Zsombor J. Földi* \\ * - Ludwig-Maximilians-Universität München. Email: zsombor.foeldi@lmu.de
}

\begin{abstract}
The paper contains the re-edition of an Old Babylonian court document from KārŠamaš/Sippar, half of which has already been known as YOS 12, 321, the other half was previously unpublished. In order to reach a satisfactory legal interpretation, the archival and prosopographical background of the document are likewise studied.
\end{abstract}

Keywords: Old Babylonian period, Kār-Šamaš, Sippar, history of law, sale of immovables, local authorities

Cite as Földi, Zs. J. 2020: The property of the city, the property of the king? A new fragment of YOS 12, 321. Hungarian Assyriological Review 1, 43-59.

https://doi.org/10.52093/hara-202001-00004-000

(c)(P) This is an open access article distributed under the terms of the Creative Commons Attribution License, which permits unrestricted use, distribution, and reproduction in any medium, provided the original author and source are credited.

While reading through the unpublished Old Babylonian trial documents at the Yale Babylonian Collection in 2015, ${ }^{1}$ the author came across YBC 10839, one half of a tablet with a piece of the envelope adhering to it. This artefact was described in G. Beckman's excellent catalogue as 'Fragmentary tablet and fragment of case-legal case concerning house; sealed', with date lost. ${ }^{2}$ The preserved end of king Samsu-ilūna's name in the oath formula ${ }^{3}$ and the prosopographical data suggested a connection with YBC 4479 (YOS 12, 321). Upon examination of both fragments, a direct join between the two could be established.

YOS 12, 321 has already been edited, once by J. D. Fortner in his unpublished PhD thesis and once by D. Charpin in a review article. ${ }^{4}$ What follows here is a re-edition of the entire document in its current state of preservation, with transliteration, transcription, translation, philological notes and interpretation.

Autograph: YOS 12, 321 (YBC 4479 only). Mus. no.: YBC 4479(A)+YBC 10839(B). Date: Si 10/11/01

1 Several of the 'Larsa' documents of the same group are studied in the author's PhD thesis (Földi 2018), which is currently being prepared for publication.

2 Beckman 2000, 216.

3 Feigin's YOS 12 contains the majority of dated tablets from Samsu-ilūna's reign bearing museum numbers between YBC 3315 (YOS 12, 168) and YBC 9101 (YOS 12, 309), but not those with lower or higher numbers. Only a handful of the latter have been published in the meantime: see, e.g., the texts Fs. Houwink ten Cate 309; Anatolica 41, 24f.; ZA 106, 156ff. nos. 6-10 and 15. Of the unpublished YBC tablets from the reign of Samsu-ilūna, YBC 4478 and YBC 8591 are studied in the author's thesis (Földi 2018) while YBC 10437 and YBC 11976 will be edited in separate studies.

4 Fortner 1996, 888-889 and Charpin 2005, 144 with n. 52. 


\section{Transliteration $^{5}$}

tablet

obv.

A1.)

1 SAR 'É' DÙ.A

A2.)

É dUTU-ra-bi

A3.)

A4.)

IDUMU-er-ṣe-tim

A5.)

DUMU pa-rla'-ìr-ra

A6.)

A7|B1'.)

B2'.)

B3'.)

B4'.)

B5’.)

B6’.) ŠÁM É ù 「ma-na?-[h]]a-tim

B7’.) I $i b-n i^{-\mathrm{d}}$ MAR.TU

B8'.) DUMU dUTU-ra-bi

B9’.) гa-na DUMU-er`-șe-tim

lo.e.

B10’) $\quad$ DUMU ${ }^{\circ} p a^{\circ}-l a-i ̀ r-r a$

B11'.) 「2?[+X GÍN] 「KÙ.BABBAR? [IN.NA.AN.L]Á?

rev.

B12') INIM.BI 'AL'?[TIL]

B13’) 「U ${ }_{4}^{7}$.[KÚR.Š̀̀ LÚ.LÚ.RA INIM NU.ĜÁ.Ĝ]Á?

B14'.) $\quad \mathrm{M}[\mathrm{U}$... ù sa-am-su]-i-lu-na

B15') [IN.PÀD.(MEŠ)]

(a number of lines hidden by the case ${ }^{6}$ )

A1'.) IGI $i a-d\left[a^{?}-a h^{?}-\ldots\right]$

A2'.) DUMU a-hi-гi?

A3'.)

up.e.

A4')

A5'.) case

obv.

B1.) [1 SAR] 'É' DÙ.[A]

B2.) $\quad{ }^{\circ}$ ' d UTU-r[a-bi ...]

B3.) IDUMU-er-ṣ[e-tim ...]

B4.) DUMU pa-la-ìr-[r]a

B5.) KI šar-rum(-)[(...) i-ša-am-ma]

B6.) Ii $i b-n i-\left[{ }^{\mathrm{d}} \mathrm{MAR} . \mathrm{TU}\right]$

B7.) 'DUMU ${ }^{d} U T U 1-[r a-b i]$

A1'.) $\quad$ ir-g[u]-um-[ma $]$

A2'.) $\quad r a-[b] i-a-[n u-u] m$

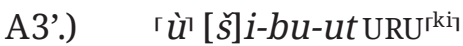

A4') $\quad i[z]-\left\ulcorner z i^{i}-i-z u\right.$

A5'.) $\quad u[\check{s}-t] a m-g i-r u-\left\ulcorner\check{s} u^{1}-n u-t i\right.$

A6’.) 「ร̌ÁM É' ù ma-na-「ḩa'-t[im]

A7’.) [2+X GÍ $] \mathrm{N}^{\circ} \mathrm{KÙ.BABBAR}$

A8'.) $\quad\left[{ }^{\mathrm{I}} i b-n\right] i^{-\mathrm{d}} \mathrm{MAR} . \mathrm{TU}$

lo.e.

A9'.) [DUMU dU]TU-ra-bi

A10’) [a-na D]UMU-er-șe-tim

rev.

A11'.) DUMU' [pa-la-ìr-ra]

A12’) $\quad i \check{s}-q\left[u^{?}-u l \ldots\right]$

A13') INI[M.BI AL.TIL]

A14'.) U U. [KÚR.ŠÈ LÚ.LÚ.RA]

A15’) I[NIM NU.ĜÁ.ĜÁ?]

[about 4 broken lines]

$\begin{array}{ll}\text { A1”.) } & \text { I[GI ...] } \\ \text { A2”.) } & \text { I[GI ...] } \\ \text { A3”.) } & \text { I[GI ...] } \\ \text { A4”.) } & \text { I[GI ...] }\end{array}$

5 For the autographs see Fig. 1-2. In order to avoid confusion, the transliteration uses the line numbering of YOS 12, 321 for YBC 4479 (A).

$6 \quad$ One wonders if the corresponding lines could be revealed by using an X-ray micro CT-scanner, such as in the case of the recent - and successful - attempts described in Ngan-Tillard - de Boer 2018 and Siddall - Raymond - Bevitt 2018. 


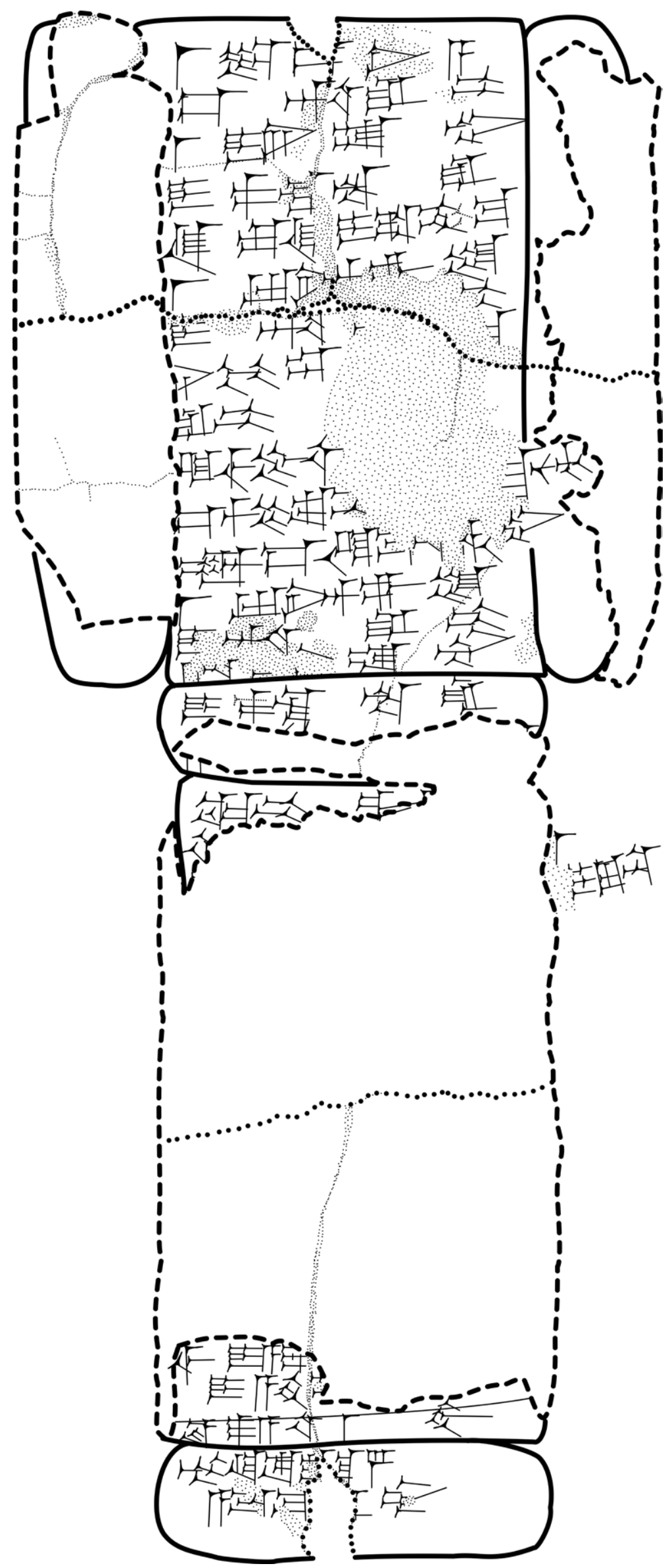




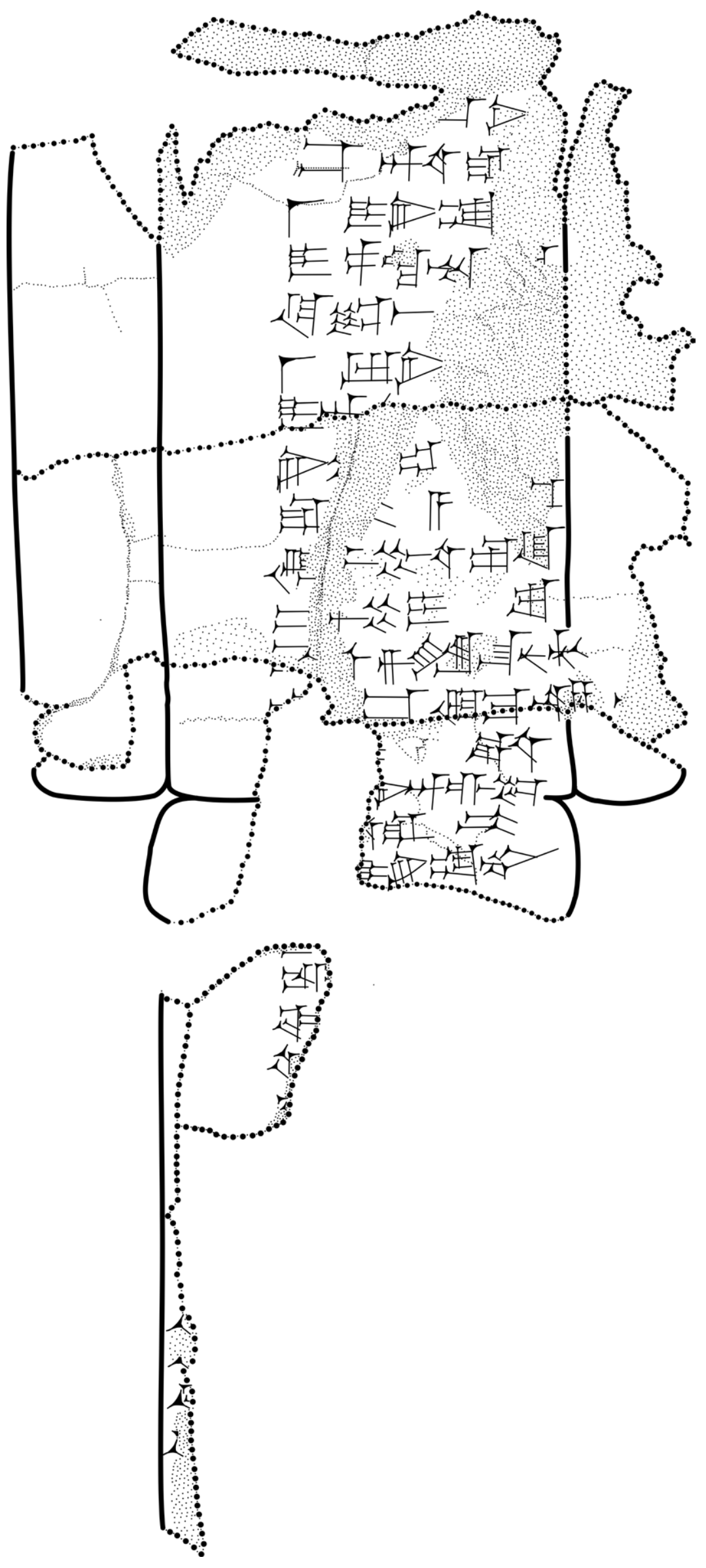

FIGURE 2. YBC 4479+10839 case. (c) Zs. J. Földi. 

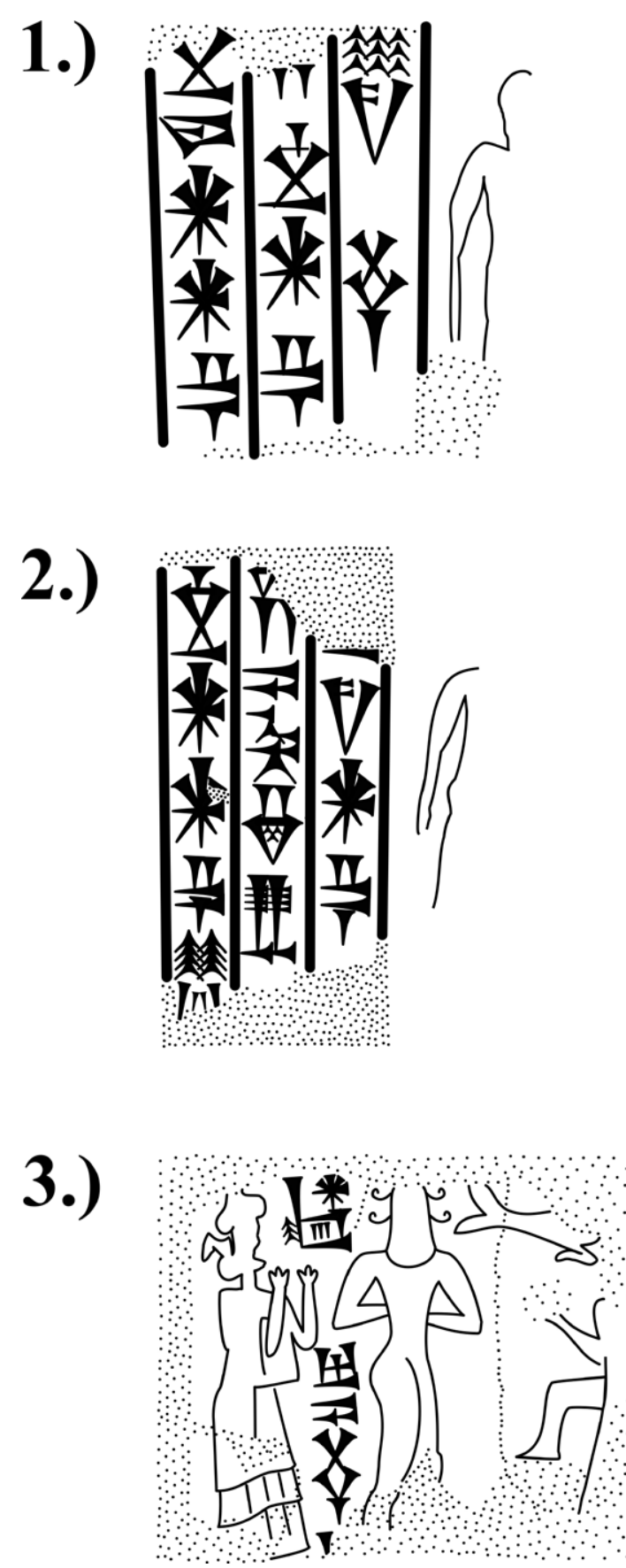
seals $^{7}$

1.) in-bu-[ša]

[DU]MU ARAD-d MAR.[TU]

[A]RAD NíG ${ }^{d} A N . M A R .[T U]$

2.) [i] $b^{?}-n i$ - ${ }^{\mathrm{d}} \mathrm{MAR} .[\mathrm{TU}]$

(inscription $1.1 \times ? \mathrm{~cm}$ )

'DUMU' a-ḩa-am-nir-[ši]

ARAD ${ }^{\mathrm{d} \Gamma}$ AN ${ }^{1}$.MAR.T[U]

3.) $\quad{ }^{\mathrm{d}} \mathrm{EN} \cdot \mathrm{ZU}-a-b u-s ̌[u]$

\section{Transcription}

1 mūšar bītam epšam bīt Šamaš-rabi Mār-erșetim mār Pala-Irra itti ālim/šarrum(-...) išām-ma Ibni-Amurrum mār Šamaš-rabi irgum-ma rabiānum u šībūt ālim izzizū uštamgirūšunūti

šìm bītim u mānahātim (case: 2+ šiqil kaspam) Ibni-Amurrum mār Šamaš-rabi ana Mār-erșetim mār Pala-Irra (tablet: 2+ šiqil kaspam) išqul. awāssu gamrat. ana matīma aḩum ana aḩim lā iraggamu nīš... u Samsu-ilūna itmû

\section{Translation}

1 sar $\left(=36 \mathrm{~m}^{2}\right)$ of built house, the house of Šamaš-rabi: Mār-erșetim, son of Pala-Irra bought it from the city (tablet) / from the king (or: Šarrum-[...]) (case).

Ibni-Amurrum, son of Šamaš-rabi, brought a suit (against Mār-erșetim). The mayor and the Elders of the city were present (lit. 'standing') and made them come to a mutual agreement.

(As) purchase price of the house and the (costs of the) improvements, Ibni-Amurrum, son of Šamaš-rabi, paid to Mār-erșetim, son of Pala-Irra, 2+ shekels of silver. Its transaction is complete. They swore by ... and Samsu-ilūna that one will never bring a suit against the other.

Before ...; before ...; before ...; before Yadah(?)-..., son of Ahī-...

Month XI, the 1st day; the year: 'The army of Adamaraș’ (= Si 10).

Seals: Inbuša, son of Warad-Amurrum, the servant of An-Martu. Ibni(?)-Amurrum, son of Ahamnirši, the servant of An-Martu. Sîn-abūšu.

\section{Philological notes}

A1, A4'-5': the damage of the signs É, LU and RA shows that a small fragment of YBC 4479 broke off and has been lost since it was copied by Feigin.

A5//B5: While the tablet has 'the city', the case offers šarrum(-)[...]. In view of the fragmentarily preserved nature of the latter, three interpretations of its fifth line are possible:

a) šar-rum might designate the king. Sales of immovables by Old Babylonian kings have recently been studied in detail by D. Charpin. ${ }^{8}$ Immovables without an owner (e.g., those of extinct families) could be assigned to a new owner by either the city or the king. This suggests that at least in some instances the city administered not only its own land but royal estates as well. ${ }^{9}$ The average length of the lines on the case discourages restoring any text between šarrum and the verb.

\footnotetext{
7 See Fig. 3.

8 Charpin 2018.

9 Földi 2018, 479-480.
} 
Grammatically, however, one would expect šarrim in the genitive, i.e. KI šar-ri-im, just as in the royal land sale contracts BDHP 28: 11 and CT 45, 121: 7 (both from Sippar). ${ }^{10}$ Some other documents from the Old Babylonian period, in fact, show šar-rum where šarrim is expected: ${ }^{11}$ whether these should be explained as the use of a rare syllabic value $\operatorname{rim}_{5}(\mathrm{AS}),{ }^{12}$ as an 'honorific nominative', ${ }^{13}$ as a false case-ending ('Kasusfehler') or as an eventual use of šar-rum as a 'Quasi-Logogramm' for 'king' (i.e. irrespective of the actual grammatical case), it is quite possible that the house in YOS 12, 321+ was sold by the king, be he Hammurāpi or Samsu-ilūna.

b) šar-rum might be the first component of the name of the city, such as Šarrum-laba. ${ }^{14}$ However, against this interpretation is the fact that similar documents with a town occurring as seller do not as a rule mention it by name: disregarding references to 'the mayor of GN' and 'the Elders of GN', the only certain exception to this pattern known so far is MHET 2/1, 96 ('the city of Tuhāmum'). ${ }^{15}$ Furthermore, since Inbuša, who sealed YOS 12, 321+, was identified in VS 29, 19 (Si 25/12/17): 10 as one of the Elders of Kār-Šamaš (see below), ${ }^{16}$ it is likely that the seller, if a city, was Kār-Šamaš.

c) šar-rum might belong to the name of a person, i.e. a member of the group representing the city and acting as seller. Whenever there is only one person leading 'the Elders of the city', he usually turns out to be the mayor (rabiānum) of that town. ${ }^{17}$ In YOS 12, 321+, the restoration of šarrum-[...] would most probably result in a theophoric name of the type Šarrum-DN, 'DN is king'. ${ }^{18}$ A mayor whose name begins with šarrum- is so far unknown. ${ }^{19}$ One might assume that Šarrum-DN was a by-form of the more common ${ }^{\mathrm{m}} \mathrm{DN}$-šarrum (its female equivalent being ${ }^{\mathrm{f}} \mathrm{DN}$-šarrat), but there is no prosopographical evidence to confirm this. The two forms, in fact, can appear (and thus be differentiated) in one and the same text. ${ }^{20}$ For this reason, the appearance of an Adad-šarrum, son of Šamāyatum as witness in the Kār-Šamaš text VS 29, 19 (Si 25/12/17): 39'21 should not be connected with šarrum-[...] in YOS 12, 321+.22

10 For recent editions of these two documents see Charpin 2018, 115-116 and 117-118, respectively.

11 Some examples: AbB 12, 172: 14' (explained by Worthington 2012, 193 as an 'honorific nominative'); mostly in the expression șimdat šarrim 'royal decree': RA 63, 189f. = StD 11, 164: rev. 10' (Edict of Ammī-șadūqa §4, compare Kraus 1984, 146 n. 287); BIN 7, 208: 13 and 209: 13; JCSS 2, 36: 15(!); RSO NS 82 Suppl. 1, 37: 10 (cf. also 49: 12).

12 See von Soden - Röllig ${ }^{4} 1991,1$ no. 1 . Disregarding the aforementioned cases of šar-rum, their only example was Sumer 7, 154ff.: rev. 13', a mathematical text from Šaduppûm; this may be supplemented by YOS 13, 10: 1 (eqlam ana ha-ra-rum, see Lieberman 1977, 111 n. 348) and AbB 1, 135: 38 (ana eqlim maka-rum). As for OBTIV 114: 2, Greengus's (1986, 3) reading / $\mathrm{rim}_{5} /$ was discarded by Dalley $(1989,642)$.

13 See Worthington 2012, 190-198, esp. 193 for Old Babylonian examples.

14 On that town in the Sippar region see De Graef 2002 and Stol 2004, 801 with n. 1097.

15 For an overview of the corpus of real estate sales by the local authorities see Charpin 2005, 140-142.

16 See Charpin 2005, 144 n. 52. The same individual occurs as witness in YOS 12, 556: case '34'.

17 A notable exception is VS 29, 19 ( $\mathrm{Si}$ 25/12/17), where the leading person is designated as laputtûm (NU.BÀNDA) 'overseer'. Prosopographical evidence from Kutalla shows that the same individual could be referred to as 'mayor' (rabiānum), rabi sikkatim-official and NU.BÀNDA (PA) at the same time, see Charpin 1980, 191-193.

18 Compare Bowes 1987, 1225-1228; see also Nakata 1995, 241.

19 Compare Seri 2003, 236-250.

20 For some examples see Archibab 1, 3; CT 33, 28; MHET 2/6, 870. AbB 13, 136 is a letter sent by a ŠarrumAdad: he makes mention of an Adad-šarrum whom he had sent to the addressee. These attestations do not point to a male/female differentiation (on such names see Durand 1988, 395 and Charpin 1993, 88).

21 The seal of the same individual appears on VS 18, 17 (collated; see below).

22 A mayor called Adad-šarrum appears in TJDB pl. 47 MAH 16.414 (Si 04?/01/25), but prosopography does not suggest a connection with the Kār-Šamaš texts. 
B5'//A5': The space in B5' is too little to restore $u\left[\check{s}\right.$-ta-am-gi-ru-šs]u-nu-ti. ${ }^{23}$ As the case appears to have -tam- ${ }^{24}$ it is not necessary to emend -〈am»-on the tablet either.

B9': The new fragment confirms ana Mār-erșetim (as suggested by Charpin) and thus excludes Fortner's ana Ibni-Amurrum.

A1"-4": Interestingly, the indentation on the case was discarded for the list of witnesses. For a similar case see VS 13, 63a (from 'Larsa').

Seal 1: Unpublished impressions of the same seal can be found on VS 29, 19 (collated; see below).

Seal 2: Epigraphically, both [i] b-ni- and [ș]i-lí- are possible. Since the PN Șillī-Amurrum is not attested in documents from the Sippar region, the former restoration is preferred.

Seal 3: The proportions of the imagery make it unlikely that a DUMU sign preceded the preserved name. One must therefore assume that Sîn-abūšu was the name of the (original) seal owner. Whether or not he was identical to Sîn-abūšu, whose son Sîn-erībam witnessed the Kār-Šamaš documents MHET 1/1, 1 (Si 30/10/10) ${ }^{25}$ and YOS 12, 537 (Si 30/[11?]/20), cannot be determined. It likewise remains unclear whether or not the inscription had any further lines.

\section{Archival and prosopographical background}

As already mentioned, prosopography strongly suggests that this document originates from KārŠamaš ${ }^{26}$ a military establishment to the northwest of Sippar (Abu Habbah). ${ }^{27}$ It belongs to a file related to the activities of Ibni-Amurrum, son of Šamaš-rabi, the protagonist in YOS 12, 321+, and those of his family. ${ }^{28}$ Although it is striking to find Ibni-Amurrum's seal impression on a document purportedly from his own archive (YOS 12, 536, see below), parallel cases from regular excavations show that this was at least sometimes possible. ${ }^{29}$ What follows is a list of documents in which Ibni-Amurrum, son of Šamaš-rabi and Mār-erșetim, son of Šamaš-rabi appear: ${ }^{30}$

23 Cf. Fortner 1996, 888; Charpin 2005, 144 n. 52 and Dombradi 2007, 264 n. 108; compare also Dombradi 1996, II, 24 and n. 2545.

24 For the same spelling see RA 91, 138f.: 38.

25 Note that MHET 1/1, 1 was sealed by Sîn-erībam, but the poorly preserved impression has not been published; only a kišib-caption reveals this (Van Lerberghe - Voet 1991, 148 S. 7).

26 See van Koppen 2003-2004, 387 and Charpin 2005, 144; cf. Dombradi 1996, II, 359 'Unb. 14’ and Seri 2005, 88, 150 and 157 (unknown/uncertain provenance), Fortner 1996, 888 (southern Babylonia). As emphasized by van Koppen, this does not necessarily mean that the tablet itself was found there: it probably comes from Sippar.

27 On Kār-Šamaš near Sippar see Dekiere 1989, 9. On other cities of the same name see now Boivin 2015 and Fiette 2017 (with earlier literature).

28 For a list of the related documents see van Koppen 2003-2004, 387 with Charpin 1981, 542; for a presumably relevant document known from the scribal education (YBC 13521) see Wagensonner forthcoming. Beckman's (2000, 56 and 209) reference to unpubl. YBC 10655 implies that the tablet belongs to the same group. A photograph kindly provided by K. Wagensonner reveals that this is not the case: This text, dated to Hुa 38/09(!), is a loan of barley from Bēlessunu, the nadītum-priestess to Sîn-māgir, son of WaradŠamaš. The first witness was Ipqu/Ipiq(SIG)-DN, son of Ha[...], the names of the remaining witnesses are either lost or hidden by the case fragment adhering to the tablet. While Bēlessunu, daughter of Mār-Sippar, attested in YOS 12, 536 is indeed the only naditum-priestess of this name in the YOS 12 texts (see Feigin 1979, 30), there were several others called Bēlessunu. On Bēlessunu, daughter of Ikūn-pî-Sîn see Harris 1962, 4; for three more naditum-priestesses of the same name see Malul 1991, 238. The case fragment of unpubl. YBC 10655 may preserve the father's name as a-di-m[a-ti-DN].

29 See, for instance, the seal of Ur-Utu on tablets from his own archive (Van Lerberghe - Voet 1991, 157159).

30 G. Kalla (pers. comm.) assigned unpubl. BM $13126(96-3-28,217)$ to the same dossier. That document is an account of wool(?), delivered by 22 men (Figulla 1961, 89). Whether YOS 13, 421 belongs to the same 
Text

YOS 12, 321+

(YBC 4479+10839)

YOS 12, 549

(YBC 4922)

YOS 13, 470 §6

Si 25

(Si 30+)

VS $29,19^{33}$

(VAT 749

+VAT 2104

+VAT 2133

+VAT 2163

+VAT 3672

+VAT 3673

+VAT 3674)
Date

Si 10/11/01

Ibni-Amurrum, son of Šamaš-rabi purchases his father's former house $\left(36 \mathrm{~m}^{2}\right)$ from Mār-erșetim, son of Pala-Irra, who had bought it from the city (var.: from the king), for 2+ shekels of silver.

Witnesses: (...); Yadah(?)-..., son of Ahī-[...].

Seals: Inbuša, son of Warad-Amurrum, the servant of An-Martu. Ibni(?)-Amurrum, son of Aham-nirši, the servant of An-Martu. Sîn-abūšu.

Si ?31/06/06+ Šamaš-ilī, son of Pilah-Adad loans [x] shekels of silver from Mār-erșetim, son of Šamaš-rabi, to buy reed mats.

Witnesses: Tarībatum, son of Iddiyyatum; Sîn-erībam, son of Na-x-da-[...]; Liwwir-Bābilim.

Seals: (unpublished). ${ }^{32}$

Ibni-Amurrum, son of Šamaš-rabi purchases a field (21600 $\mathrm{m}^{2}$ ) in the Ašukum meadow on the Euphrates, with tower and kislah plot from Narāmtani, the nadītum-priestess of Šamaš, daughter of Mannum-kīma-Sîn.

(Neighbours: the Euphrates, the field of Ili-iddinam, the [Haru-mālik canal] and the Balala channel.)

Si 25/12/17 Mār-erșetim, son of Šamaš-rabi purchases a kislah plot $\left(108 \mathrm{~m}^{2}\right)$ from Nakarum, the laputtûm-overseer; Marduk -nāṣir, son of Apil-ilišsu; Qaqqadum, son of Ahumwaqar; ...-Arahtu(?), son of Šu-Nintu; Inbuša, son of Warad-Amurrum; Paluh-rigimšu and KUya'ûm, the sons of Ibni-Adad; Ilī-imguranni, son of Mār-erșetim; Ilšu-ibnišu, son of Bēlšunu; Iddin-Sîn, son of Annum-pîša; Mār-erșetim, son of Šamaš-massû; Ibni-Amurrum, son of Hुāzirum; Awīl-Adad,sonof...;Hurrurum,sonofSîn-māgir;Tappa-wēdim, son of Ipquša; Kī-maruș, son of Pala-Irra; Ipqu-Ištar, son of Ballallu(?); ...; Ilī-ippalsa(?), son of Bēlšunu; Ilšu-bāni, son of Sîn-iqī̌šam, (case adds: ..., the mayor(?) ...; Šamaš(?)-nāșir, son of Ali-waqrum) and many (others) of the Elders of Kār-Šamaš, for 7 shekels of silver.

(Neighbours: Kī-maruṣ, son of Pala-Irra; Balāya; the street; ....)

Witnesses: Ilšu-abūšu, son of Waqar-awīlum; Adad-šarrum, son of Šamāyatum; Amurrum-nāșir, son of Šamaš-nāșir; Aplatum, son of Mār-erșetim; KURtum, son of Ipqatum; Pirhuum, son of Mār-Ištar; Annum-pî-Ilabrat, scribe.

group or not cannot be determined (van Koppen 2003-2004, 387 n. 43).

31 See Horsnell 1999, II, 234-235.

32 Beckman 2000, 53.

33 Collated; for an edition see Charpin 2005, 134-136. 
Text

VS 29,19

(continued)

VS $18,17^{34}$

(VAT 5998)

\section{Date}

Si 25/12/17

Si 26/09/25
(YBC 4976)

\section{YOS 13, 13 §1}

Si $28 / 07 / 26$

(Aș

01/04/24)

\section{Contents}

Seals: Aplatum, son of Mār-erșetim, the servant of An-Martu. Iddin-Sîn, son of Annum-pîša, the servant of An-Martu. .... [...]-erība, .... Qaqqadum, son of Ahum-waqar, the servant of An-Martu. Paluh-rigimšu, son of Ibni-Adad, the servant of Adad(?). Inbuša, son of Warad-Amurrum, the servant of An-Martu.

KURtum, son of Ipqatum purchases a kislah plot $\left(54 \mathrm{~m}^{2}\right)$ from Ilšu-ibnišu, the mayor of Kār-Šamaš; Qaqqadum, son of Ahum-waqar; Iddin-Bunene, son of Šu-Nintu; Paluh-rigimšu and KUya'ûm, the sons of Ibni-Adad; Nakarum, son of Warad -Amurrum; (case adds: Kī-maruṣ, son of Pala-Irra;) Iddin-Sîn, son of Annum-pî̌̌a; Sîn-iqī̌sam, son of Hyadna(?)-ilī; Mār-erṣetim,sonofŠamaš-massû;Ipqu-Ištar,sonofBallallu(?);Bēlānum, son of Abāyatum and many (others) of the Elders of KārŠamaš, for $21 / 2$ shekels of silver.

(Neighbours: a house that the buyer had bought from the city in Si 25; the street; a broad street and a plot of the city.)

Witnesses: (case adds: Mār-erșetim, son of [Šamaš-rabi];) Ilšu-abūšu, son of Waqar-awīlum; Ilī-imguranni, son of Mār-erșetim; Ilšu-ibnišu, son of Bēlšunu; Mār-erșetim and (H)āṣibum, the sons of Aqbahum; Amurrum-nāșir, son of Šamaš-nāṣir; Attāya, the goldsmith, son of Šummuhum;

(case adds: Aplatum, son of Mār-erșetim;) Tarībum, son of Ilīiqīšam; Annum-pî-Ilabrat, scribe.

Seals: Adad-šarrum, son of Šamāyatum, the servant of An-Martu. Aplatum, son of Mār-erșetim, the servant of An-Martu. Mār-erșetim, son of Šamaš-rabi, the servant of S[în]. The seal of Tarībum. KUya'ûm, ${ }^{35}$ son of Ibni-Adad, the servant of Adad. Irra-muballiț, son of Hāzirum, the servant of Lugal-Gudua and .... Iddin-Sîn, son of Annum-pîša, the servant of An-Martu. ..., son of ..., the servant of S[în](?) and An-Martu. Mār-erșetim, ....

Mār-erșetim, son of Šamaš-rabi purchases a kislaḩ plot (57 $\mathrm{m}^{2}$ ) on the [...] street from Narāmtani, the nadìtum-priestess of Šamaš and Sîn-ublam, son of Nabi-Sîn, for 26 shekels of silver.

(Neighbours: the buyer; Sîn-ippalsam, son of Aham-nirši; the Uraš street; the house of the sellers; the Abubāya street.)

34 Collated; see Földi forthcoming. For an edition see Charpin 2005, 136-139.

35 Colbow's (1996, 53 no. 6) description reveals that this must be identical with an unpublished seal on VS 18, 17 (collated); see Földi forthcoming. 
YOS 13, $13 \S 2$

(YBC 4976)

YOS $12,536^{36}$

Si 30/08/[?]

(YBC 4981)

YOS 12, 537

(YBC 4222)

(Aș

JCS 31, 142 no. 15 Si 29/06/12
Si 29/01/10 Mār-erșetim, son of Šamaš-rabi purchases a kislah plot (108

01/04/24) (Neighbours: Sîn-ippalsam, son of Aham-nirši; the buyer; the Uraš street.)

Mār-erșetim, son of Šamaš-rabi, Šamaš-nāṣir and ... deliver 12 shekels of silver to Babylon.....

Witness: Ilšu-abūšu, son of Waqar-awīlum.

Seals: (unpublished).

Ibni-Amurrum, son of Šamaš-rabi exchanges a house $\left(36 \mathrm{~m}^{2}\right.$; neighbours: Ibni-Amurrum; Ilī-awīlim and Ilšu-bāni, the sons of Mār-Sippar, son(?) of Sîn-adallal; ${ }^{37}$ the street; Paluhrigimšu) with Bēlessunu, the nadītum-priestess of Šamaš and daughter of Mār-Sippar, for a house $\left(36 \mathrm{~m}^{2}\right.$; neighbours: the ... courtyard in Kār-Šamaš; Ibni-Amurrum, son of Šamaš-rabi; the street) in Kār-Šamaš.

Witnesses: Ilšu-ibnišu, the mayor of Kār-Šamaš; IpquAnnunītum, son ofAli-bānīšu;Ipqu-Aya, son ofŠamaš-tappêšu; Ibbi-Šamaš, son of Nanna-manšum(!); KUya'ûm, son of Ibni-Adad; Aplatum, son of Mār-erșetim; Pirhuum, son of MārIštar; Annum-pî-Ilabrat, scribe.

Seals: Ibni-Amurrum, son of Šamaš-rabi, the servant of Sî[n] and An-Martu. Ilšu-ibnišu, son of Mār-erșetim, the servant of .... Ipqu-Annunītum, son of Ali-bānīšu, the servant of the Ebabbar. The seal of Ibbi-Šamaš. Ipqu-Aya, son of Šamaš-tappêšu, the servant of the Ebabbar. KUya'ûm(!), ${ }^{38}$ son of Ibni-Adad, the servant of Adad. Pirhum, son of Mār-Ištar, the servant of An-Martu. Aplatum, son of Mār-erșetim, the servant of An-Martu. ..., son of Tarībatum, the servant of Nabûm.

Si 30/[11?]/20 Ibni-Amurrum, son of Šamaš-rabi purchases a house ([...] m², 'the rest of the house that was left') in Kār-Šamaš from Ilīawīlim and Ilšu-bāni, the sons of Mār-Sippar, for 10 shekels of silver.

(Neighbours: the buyer; the street; Paluh-rigimšu.)

Witnesses: Marduk-nāṣir, the mayor of Kār-Šamaš; IbbiŠamaš, son of Nanna-manšum(!); Ilšu-ibnišu, son of Mār-erșetim; KUya'ûm, son of Ibni-Adad; Sîn-erībam, son of Sînabūšu; Annum-pî-Ilabrat, scribe.

Seals: (unpublished). ${ }^{39}$

\footnotetext{
36 For a transliteration see Colbow 1996, 60.

37 Read DUMU.MEŠ DUMU-「ZIMBIR ${ }^{\mathrm{ki}}$ [(DUMU?) ${ }^{\mathrm{d}}$ E]N.ZU-a-da-làl; discard Colbow’s (1996, 60): [r] $i^{\text {? }}$-ba-a-tá-am.

38 See note 25 above.

39 Beckman 2000, 27.
} 
It has been assumed that Ibni-Amurrum, son of Šamaš-rabi, and Mār-erșetim, son of Šamaš-rabi, were brothers. ${ }^{40}$ Although this is certainly possible and to some extent even probable, it cannot be confirmed with absolute certainty: while the former described himself as 'servant of Sî[n] and An-Martu' in his seal inscription, ${ }^{41}$ the latter referred to himself as 'servant of S[în]', ${ }^{42}$ and it cannot be determined whether or not there was a fourth line adding 'and An-Martu' ${ }^{43}$ Furthermore, it is striking to see that neither Ibni-Amurrum nor Mār-erșetim witnessed any of the other's real estate contracts, as many parallels would lead one to expect. Should the unpubl. YBC 13521 preserved in scribal education imply that Ibni-Amurrum had two brothers called Mār-erșetim and Mār-Purattim, ${ }^{44}$ the reason for this negligence might be the legal debate between them.

It is possible that Iltāni, daughter of Ibni-Amurrum, to whom a certain Narāmtani, daughter of Etel-pî-Marduk, had granted a field, ${ }^{45}$ was the same Ibni-Amurrum's daughter. The same might apply to Lamassāni, the nadītum-priestess of Šamaš and daughter of Ibni-Amurrum, as well as to her brother Bēlšunu. ${ }^{46}$ As Ibni-Amurrum was a very common name, and Ibni-Amurrum, son of Šamaš-rabi was still active by the end of $\mathrm{Si} 30,{ }^{47}$ the latter identification is rather unlikely.

\section{Legal interpretation}

What did happen to the house discussed in YOS 12, 321+? To sum up the facts, Ibni-Amurrum, son of Šamaš-rabi bought a house that once belonged to his father but was sold by the city to a certain Mār-erșetim. It was presumably Mār-erșetim from whom Ibni-Amurrum claimed his father's house. The local authorities, i.e the mayor and the city elders, assumed the task of mediating between the two parties. As a result of this mediation, Ibni-Amurrum could acquire the house by paying the original purchase price and what Mār-erșetim had spent on the house since. Although the wording of the document does not follow the usual pattern of purchase documents, it had the same function, namely, it served as a deed of ownership.

Our understanding of the legal background depends on the reconstruction of the untold part of the story. For A. Seri this text 'lets us suspect that the circumstances under which the city sold a house might not have been transparent'. ${ }^{48}$ She further envisages a conflict between an assumed general assembly, i.e. which sold the house, and the mayor and the city elders who had revoked a sale. ${ }^{49}$

Interestingly, the house is said to have been sold not by Šamaš-rabi himself, but by the local authorities (var. the king, see below). Still, the contract stipulates that it was Šamaš-rabi's house. How is this seeming contradiction possible? Trial documents usually begin with a clause 'concerning (the house etc.) that ...' (aššum ...) summarising the history of the property under discussion. This description sometimes contains information that actually results from the trial itself,

\footnotetext{
40 See van Koppen 2003-2004, 387.

41 YOS 12, 536 seal 1 with Colbow 1996, no. 1.

42 VS 18,17 seal *3.

43 On family gods and their importance for the reconstruction of family trees see Charpin 1990.

44 See Wagensonner forthcoming.

45 YOS 13, 470 §7. The register itself is undated but reveals that the bequest took place in Si 30.

46 See MHET 1/1, 1 (Si 30/10/10) and 2 (Si 30/10/15).

47 See esp. YOS 12, 537, dated to Si 30/[11?]/20 (also Charpin 2005, 138 n. 7).

48 Seri 2005, 88.

49 Seri 2005, 88 and 155; also Stol 2007, 214.
} 
i.e. details that have been ascertained or confirmed by the legal investigation. ${ }^{50}$ This does not necessarily apply to YOS 12, 321+, as this document does not begin with aššum 'concerning'. Could the city sell a house as if it was its own property? Such a flagrantly act on the part of the city seems implausible. But why did Šamaš-rabi not sell his house himself?

It can be assumed that at the time of Šamaš-rabi’s death his sons were still very young. Although the sale took place an unspecified amount of time before Si 10 (the date of YOS 12, 321+) and the corresponding purchase contract is lost, this assumption finds some corroboration in the span of time between Si 10 and the later documents in which Ibni-Amurrum acquired real estates (Si 25 and Si 30). If one does not want to accuse the local authorities of depriving the family of its house and selling it as their own, one might assume that the city undertook a kind of guardianship of Šamaš-rabi's children ${ }^{51}$ and sold some of their estates in order to repay Šamaš-rabi’s debts. ${ }^{52}$ One may compare the case described in the trial document VS 13, 89 ('Larsa'): ${ }^{33}$ the local authorities decided that the deceased debtor's house should be given to the creditor as a pledge for an unpaid debt of ten kor (= $3000 \mathrm{l}$ ) of barley. The contract further stipulates that the debtor's son, should he lay claim to the house and pay his father's debt, would get the house back. As the loan itself was interest-free (usātum), no interest would be charged. In YOS 12, 321+, however, the verbs used imply that Mār-erșetim could not be the creditor himself: he 'bought' (išām) the house from the town and it was not 'given' to him.

With respect to Ibni-Amurrum, the situation is reminiscent of estates sold by the father and, later on, redeemed (pațārum) by his son. ${ }^{54}$ On the one hand, neither Mār-erșetim nor the local authorities seem to have had doubts about Ibni-Amurrum's right to buy his father's house back. ${ }^{55}$ The debate might be rather about whether or not Mār-erșetim should be compensated for the costs of the improvements he had made to the house. Nothing implies that the town was to compensate Ibni-Amurrum for an unlawful sale of his father's house; the city seems to have acted as mediator instead of being involved as a party.

It is therefore to be assumed that Mār-erșetim's purchase of Šamaš-rabi's house was legal. But how could the city act in the name of Šamaš-rabi's family? Field rental contracts show that the Elders of a city could act on behalf of the field owner: in YOS 13, 490 (Ad 12/08/20), ${ }^{56}$ the elders of Kār-Šamaš rented out a corvée worker's field to princess Iltāni. ${ }^{57}$ In spite of this, it is hard to imag-

50 Földi 2018, 403-404. Compare, for instance, the introduction of CHJ, HE 143 = RA 11, 178: 'concerning Ahāssunu whom Dadāya, son of Nūr-ilīšu, the manager of herds had taken from Qullupat, her wet nurse, at the opening of the city gate of Larsa'.

51 Compare RA 85, 48 no. 23 = MHET 2/3, 420 (Si 11/05/01), where the guardianship of the children of a certain Māri-Amurrum was entrusted to a man called Apiyyatum. Among the witnesses one finds a field surveyor (abi ašlim) and the Overseer of the Ward (wakil bābtim); this implies some public interest in the matter.

52 Alternatively, the family might have been considered extinct (with Ibni-Amurrum appearing later), but this is unlikely in the case of a well-established family, as the purchase contracts imply.

53 Ed. Földi 2018, 243-248.

54 See Veenhof 1999, 609-616 and Westbrook 2003, 406-407 §7.5.1.; for examples see CAD P (2005), $294-295$. An Ipqu-Lisi from Larsa notoriously reclaimed the property sold by his father and his uncle; to the already known YOS 12, 353 at least three documents of this kind can be added (Földi 2018, 590-593).

55 Otherwise, as emphasized by Seri $(2005$, 88), the authorities might have punished Ibni-Amurrum for claiming without legal grounds.

56 Ed. Pomponio 1978, 87-88 no. 34.

57 The situation appears to have been similar in YOS 13, 491 (Ae 'u'/05/12). Another field in Kār-Šamaš assigned to corvée workers (i.e. not reed carriers, as the edition suggests) is mentioned in AbB 7, 110. 
ine that the same could apply to land sales as well. ${ }^{58}$ None of the corresponding sale documents with the city acting as seller suggest this.

In view of the problems discussed above, the easiest and most likely solution is to assume that it was Šamaš-rabi himself who sold his house to the city. This circumstance, since it was irrelevant to the current legal situation, was left unmentioned in YOS 12, 321+. Ibni-Amurrum could not reclaim the sold property from the original buyer (i.e. the city); instead he had to reclaim it from the current owner. Whether or not the first sale occurred because of economic duress and its re-acquisition found support in an edict of Samsu-ilūna ${ }^{59}$ cannot be determined. ${ }^{60}$

Besides the prosopographical data, the most important detail the new fragment adds is the alternative description of the seller. In spite of a degree of uncertainty, it is still the most likely interpretation that the king was named in this role (see above). But how could a house be sold by the king and by the town at the same time?

One possible explanation is that certain royal holdings could have been administered by the local authorities and this circumstance might have led to uncertainty as to the corresponding ownership rights. ${ }^{61}$ Since Kār-Šamaš was a major military establishment, there is a good reason to assume that most of its neighbourhoods belonged to the Palace. This assumption cannot yet be confirmed by means of textual evidence, though.

Alternatively, there are some sale contracts telling us what happened to the silver that the buyer paid to the city as purchase price. The local authorities used this financial source to reimburse their debts to the state, which had accrued as a result of insufficient performance in construction works: this deficit presumably made it necessary to supplement the workforce with hired workers, the costs of which were charged to the town. The following three documents are relevant in this respect: ${ }^{2}$

\begin{tabular}{|l|l|l|l|l|}
\hline \multicolumn{1}{|c|}{ text } & \multicolumn{1}{c|}{ date } & \multicolumn{1}{c|}{ town } & sum of silver & \multicolumn{1}{c|}{ arrears resulting from } \\
\hline $\begin{array}{l}\text { MHET 2/6, } \\
871\end{array}$ & Si 22/04/10 & $?^{63}$ & 7 shekels & $\begin{array}{l}\text { corvée work at the (construction) } \\
\text { works at the new channel (E GIBIL) } \\
\text { of Yamutbālum }\end{array}$ \\
\hline VS 29, 19 & Si 25/12/17 & Kār-Šamaš & 7 shekels & $\begin{array}{l}\text { corvée work at the (construction) } \\
\text { works at the diversion (takkīrum) } \\
\text { of the Arahtum canal }\end{array}$ \\
\hline VS 18, 17 & Si 26/09/25 & Kār-Šamaš & $21 / 2$ shekels & $\begin{array}{l}\text { corvée work at the (construction) } \\
\text { works at Dūr-Apil-Sîn }\end{array}$ \\
\hline
\end{tabular}

VS 18, 17 further explains that the buyer did not pay the silver to the city, but - on behalf of the city (ana pīhat ālim) - directly to a certain Egatum, whom the silver was assigned to (i.e. by the Palace) for collecting. VS 29, 19 stipulates that the buyer weighed out the silver in order to pay the Palace (ana apāl ekallim išqul). Why have these stipulations been included in contracts of private

58 As assumed by Seri $(2005,150)$.

59 On the largely unpreserved edict of Samsu-ilūna in Si 08 see Kraus 1965 and 1984, 154-160.

60 See esp. Veenhof 1999, 613-616.

61 The assignment of ownerless lands by the town or by the king has been discussed in the author's thesis (Földi 2018, 475-482).

62 See van Koppen 2003-2004, 387; Pecha 2004; Charpin 2007, 177 and most recently Stol 2015, 33-34 with n. 27.

63 The mention of the deity Bēl-șarbim points either to Bāṣum or to Hुirītum (see van Koppen 2003-2004, 387 n. 41; Charpin 2005, 141 with n. 33 and Stol 2015, 33 n. 27). 
nature? Since the one who received the purchase price was not identical to the seller, the buyer certainly felt the need to secure his rights in order to avoid future debates.

To what extent the shortage of workforce and the difficulties in collecting the arrears became typical in the reign of Hyammurāpi's son cannot yet be established with certainty, but they certainly contributed to what Stol described as 'king Samsu-ilūna's financial problems' ${ }^{64}$ The new text published by Stol (Anatolica 41, 24f.) is dated to Si 22 and deals with arrears from the year Si 12. As Stol concludes, '[a]rrears were an eternal problem in the Babylonian administration', ${ }^{65}$ often recorded throughout several years, sometimes over a decade or even more. Further examples show that the situation earlier in the reign of Samsu-ilūna was not much different. ${ }^{66}$

To sum up, there is enough evidence to suggest the following sequence of events: Šamaš-rabi sold a house plot to the city of Kār-Šamaš. The local authorities sold the same estate to Mār-erșetim. Either the property of the city of Kār-Šamaš was, in fact, the king's property or the city made Mār-erșetim pay the purchase price to the Palace; whichever was the case, it resulted in some uncertainty on the scribe's part as to the seller's identity. It was certainly after Šamaš-rabi's death that his son Ibni-Amurrum decided to reclaim his father's property. The owner was reluctant to give the house back, as he did not want to lose the money he had invested in improving the building. Through the mediation of the local authorities an agreement could be reached: in addition to the purchase price, Ibni-Amurrum reimbursed Mār-erșetim's costs and took possession of his father's house.

\section{Acknowledgements}

The author thanks Benjamin R. Foster, Ulla Kasten and Agnete W. Lassen for permission to publish YBC 10839, as well as for their kind assistance during the author's research stay at Yale (18.09.-23.10.2015). The stay was financially supported by the Distant Worlds - Munich Graduate School for Ancient Studies at the Ludwig-Maximilians-Universität München. Enrique Jiménez was kind enough to confirm the join and took excellent photographs of the artefact. Klaus Wagensonner generously provided a scan of the unpublished tablet YBC 10655 and permitted to refer to his forthcoming paper on YBC 13521. Gábor Kalla, Frans van Koppen, Anna Kurmangaliev and Sarah P. Schlüter gave useful insights and Mary Frazer improved the English style. The author, needless to say, is solely responsible for any remaining mistakes. Relative dates throughout this paper follow the pattern RN YY/MM/DD.

\section{References}

Beckman, G. 2000: Old Babylonian Archival Texts in the Yale Babylonian Collection (ed. KAsten, U.). (Catalogue of the Babylonian Collections at Yale 4) Bethesda, Maryland.

BoIvin, O. 2015: Kār-Šamaš as a south-western palace town of the Sealand I kingdom. Nouvelles Assyriologiques Brèves et Utilitaires, 162-164 (No. 97).

Bowes, A. W. 1987: A Theological Study of Old-Babylonian Personal Names. Vol. I-II. PhD dissertation (Dropsie College). Merion, Pennsylvania [MS].

Charpin, D. 1980: Archives familiales et propriété privée en Babylonie ancienne. (Étude des documents de «Tell Sifr». École Pratique des Hautes Études 2, Hautes Études Orientales 12) Genève - Paris.

ChARPIN, D. 1981: La Babylonie de Samsu-iluna à la lumière de nouveaux documents. Bibliotheca Orientalis 38, 517-547.

ChARPIN, D. 1990: Les divinités familiales des babyloniens d’après les légendes de leurs sceaux-cylindres. In:

64 Stol 2015. The author is grateful to F. van Koppen for calling his attention to this article.

65 Stol 2015, 30.

66 See Stol 2015, 31 with examples and earlier literature. 
TuncA, Ö. (ed.): De la Babylonie à la Syrie, en passant par Mari. Mélanges offerts à Monsieur J.-R. Kupper à l'occasion de son 70e anniversaire. Liège, 59-78.

Charpin, D. 1993: Review of: W. H. van Soldt, AbB 12. Revue d'assyriologie et d'archéologie orientale 87, 87-89.

Charpin, D. 2005: Chroniques bibliographiques 5. Économie et société à Sippar et en Babylonie du Nord à l'époque paléo-babylonienne. Revue d'assyriologie et d'archéologie orientale 99, 133-176. https://doi. org/10.3917/assy.099.0133

Charpin, D. 2007: Chroniques bibliographiques 10. Économie, société et institutions paléo-babyloniennes: nouvelles sources, nouvelles approaches. Revue d'assyriologie et d'archéologie orientale 101, 147-182. https://doi.org/10.3917/assy.101.0147

Charpin, D. 2018: Dons ou ventes de terres par les rois à l'époque paléo-babylonienne. In: KLEBER, K. - NeUmann, G. - Paulus, S. (eds.): Grenzüberschreitungen. Studien zur Kulturgeschichte des Alten Orients. Festschrift für Hans Neumann zum 65. Geburtstag am 9. Mai 2018. (Dubsar 5) Münster, 99-141.

Colbow, G. 1996: Ein gesiegelter Umschlag aus Kār Šamaš und neue Aspekte zur Herkunft einiger Dokumente aus dem Ur-Utu-Archiv von Sippar-Amnānum. Northern Akkad Project Reports 9, 51-61.

DAlley, S. 1989: Review of Greengus 1986. Bibliotheca Orientalis 46, 641-645.

De Graef, K. 2002: Two Ilšu-ibni’s, two ugula gidru's. Šarrum-Labaki, a military settlement at the Irnina. Aula Orientalis 20, 61-97.

Dekiere, L. 1989: Reconstruction cadastrale de la région de Sippar. Possibilité ou utopie? Northern Akkad Project Reports 3, 7-14.

Dombradi, E. 1996: Die Darstellung des Rechtsaustrags in den altbabylonischen Prozessurkunden. I: Die Gestaltung der altbabylonischen Prozessurkunden. Der altbabylonische Zivilprozess. II: Appendix: Die Organe der Rechtsprechung. Anmerkungen - Exkurse - Indices. (Freiburger Altorientalische Studien 20) Stuttgart.

DombRADI, E. 2007: Das altbabylonische Urteil: Mediation oder res iudicata? Zur Stellung des Keilschriftrechts zwischen Rechtsanthropologie und Rechtsgeschichte. In: WiLcke, C. (ed.): Das geistige Erfassen der Welt im Alten Orient. Sprache, Religion, Kultur und Gesellschaft. Wiesbaden, 245-279.

Durand, J.-M. 1988: Archives épistolaires de Mari I/1. (Archives royales de Mari 26/1) Paris.

FeIgin, S. I. 1979†: Legal and Administrative Texts of the Reign of Samsu-iluna. (Yale Oriental Series, Babylonian Texts 12) New Haven, Connecticut.

FietTe, B. 2017: Note sur les toponymes du Sud mésopotamien, 3: Kar-Šamaš. Nouvelles Assyriologiques Brèves et Utilitaires, 128 (No. 70).

Figulla, H. H. 1961: Catalogue of the Babylonian Tablets in the British Museum, Volume I. [London].

FöLDI, Zs. J. 2018: The Trial Documents from Old Babylonian Larsa in their Legal, Economic, Social and Archival Contexts. PhD dissertation (Ludwig-Maximilians-Universität München). München [MS].

FöLDI, Zs. J. forthcoming: Nachlese zu H. Klengel, Altbabylonische Rechts- und Wirtschaftsurkunden (VS 18).

ForTnER, J. D. 1996: Adjudicating Entities and Levels of Legal Authority in Lawsuit Records of the Old Babylonian Era. PhD dissertation (Hebrew Union College-Jewish Institute of Religion). [Cincinatti] [MS].

GREENGUS, S. 1986: Studies in Ishchali Documents. (Bibliotheca Mesopotamica 19) Malibu.

HARrIs, R. 1962: Biographical Notes on the Nadìtu Women of Sippar. Journal of Cuneiform Studies 16, 1-12. https://doi.org/10.2307/1359426

Horsnell, M. J. A. 1999: The Year-Names of the First Dynasty of Babylon. Vol. I: Chronological Matters: The Year-Name System and the Date-Lists. Vol. II: The Year-Names Reconstructed and Critically Annotated in the Light of their Exemplars. Hamilton.

VAN KopPen, F. 2003-2004: Review of H. Klengel - E. Klengel-Brandt, VS 29. Archiv für Orientforschung 50, 379-392.

KraUs, F. R. 1965: Ein Edikt des Königs Samsu-iluna von Babylon. In: Güterbock, H. G. - JacobSEN, Th. (eds.): Studies in Honor of Benno Landsberger on his Seventy-Fifth Birthday April 21, 1965. (Assyriological Studies 16) Chicago, 225-231. 
Kraus, F. R. 1984: Königliche Verfügungen in altbabylonischer Zeit. (Studia et Documenta ad Iura Orientis Antiqui Pertinentia 11) Leiden.

Lieberman, S. J. 1977: The Sumerian Loanwords in Old-Babylonian Akkadian. I: Prolegomena and Evidence. (Harvard Semitic Studies 22) Missoula, Montana. https://doi.org/10.1163/9789004385795_002

Malul, M. 1991: On Nails and Pins in Old Babylonian Legal Praxis. Acta Sumerologica 13, 237-248.

NAKATA, I. 1995: A Study of Women's Theophoric Personal Names in the Old Babylonian Texts from Mari. Orient 30-31, 234-253. https://doi.org/10.5356/orient1960.30and31.234

Ngan-Tillard, D. J. M. - De Boer, R. 2018: Two Ur III Texts in the De Liagre Böhl Collection at Leiden. Bibliotheca Orientalis 75, 283-285.

Pecha, L. 2004: Towards the Payment of Arrears by Local Administrative Bodies in the Old Babylonian Period. Nouvelles Assyriologiques Brèves et Utilitaires, 97-98 (No. 96).

Pomponio, F. 1978: I contratti di affitto dei campi per la coltivazione di cereali pubblicati in YOS 13. (Annali dell'Istituto Universitario Orientale di Napoli, Supplemento 14) Napoli.

SeRI, A. R. 2003: Local Power: Structure and Function of Community Institutions of Authority in Old Babylonian Period. PhD dissertation (University of Michigan). Ann Arbor [MS].

SERI, A. R. 2005: Local Power in Old Babylonian Mesopotamia. (Studies in Egyptology and the Ancient Near East) London - Oakville.

Siddall, L. R. - Raymond, C. A. - Bevitt, J. J. 2018: Hidden Text: Imaging and Reading an Ancient Tablet Encased in an Envelope. Buried History 54, 3-10.

von Soden, W. Th. H. F. - Röllig, W. ${ }^{41991: ~ D a s ~ a k k a d i s c h e ~ S y l l a b a r . ~(A n a l e c t a ~ O r i e n t a l i a ~ 42) ~ R o m a . ~}$

Stol, M. 2004: Wirtschaft und Gesellschaft in Altbabylonischer Zeit. In: AtTinger, P. - SALlaberger, W. WÄFLER, M. (eds.): Mesopotamien. Die altbabylonische Zeit. (Orbis Biblicus et Orientalis 160/4) Freiburg - Göttingen, 641-975.

StoL, M. 2007: Review of Seri 2005. Journal of the American Oriental Society 127, 212-215.

Stol, M. 2015: King Samsu-iluna’s Financial Problems. A New Text. Anatolica 41, 23-35.

Van Lerberghe, K. - Voet, G. 1991: Sippar-Amnānum. The Ur-Utu Archive, 1. (Mesopotamian History and Environment 3, Texts 1) Ghent.

Veenhof, K. R. 1999: Redemption of Houses in Assur and Sippar. In: Böck, B. - CANCik-Kirschbaum, E. Richter, TH. (eds.): Munuscula Mesopotamica. Festschrift für Johannes Renger. (Alter Orient und Altes Testament 267) Münster, 599-616.

WAgensonner, K. forthcoming: When Legal Case Becomes Scribal Lore. Journal of Cuneiform Studies.

Westbrook, R. 2003: Old Babylonian Period. In: Westbrook, R. (ed.): A History of Ancient Near Eastern Law. Handbook of Oriental Studies, I: The Near and Middle East 72. Leiden - Boston, 361-430. https://doi. org/10.1163/9789047402091_010

Worthington, M. 2012: Principles of Akkadian Textual Criticism. (Studies in Ancient Near Eastern Records 1) Boston - Berlin. https://doi.org/10.1515/9781614510567 



\title{
Intercalary Months and Interest-bearing Loans in Babylonia. A Promissory Note from the Egibi Archive
}

\section{Zoltán Csabai*}

* - Department of Ancient History, University of Pécs. Email: csabai.zoltan@pte.hu

\begin{abstract}
In this paper a cuneiform economic document from the Egibi archive is investigated. The text is a promissory note from Babylon and was written in an intercalary month in the 6th century B.C. The study discusses how interest in the Babylonian interest-bearing loans worked and how the existence of intercalary months, a peculiarity of the Babylonian calendar, had an effect on this system.
\end{abstract}

Keywords: Egibi archive, Neo-Babylonian economic texts, interest-bearing loans, intercalary months

Cite as Csabai, Z. 2020: Intercalary Months and Interest-bearing Loans in Babylonia. A Promissory Note from the Egibi Archive. Hungarian Assyriological Review 1, 61-73.

https://doi.org/10.52093/hara-202001-00005-000

(ㄷ)(i) This is an open access article distributed under the terms of the Creative Commons Attribution License, which permits unrestricted use, distribution, and reproduction in any medium, provided the original author and source are credited.

The Mesopotamian calendar is characterized by the use of intercalation. To reconcile the difference between the twelve months lunar (354 days, consisting of 29- and 30-days months) ${ }^{1}$ and the solar calendar (ca. 365 days), intercalary months were inserted. ${ }^{2}$ Before the $1^{\text {st }}$ millennium B.C., the insertion of intercalary months was not regular, systematic and predictable. ${ }^{3}$ From the Late Achaemenid period on, and especially from the last decades of the $5^{\text {th }}$ century B.C. the 19-year cycle became regular. ${ }^{4}$ Economic and administrative sources are rarely considered in the study of intercalation; however, they can prove to be useful in identifying intercalary months as well as in examining the systematic nature of their insertion. ${ }^{5}$

In this brief study, a cuneiform economic text from the Early Achaemenid period is put under scrutiny. A special feature of the tablet, recorded in the reign of Darius I, is the fact that it was written in an intercalary month - it may even be assumed that it was the intercalary month itself that led to the drawing up of this document.

1 There is no example of a 31-day month in the regular calendars from Mesopotamia.

2 Steele 2011, 475-478. For the schemes of intercalation in the series MUL.APIN see Hunger - Pingree 1999, 75-79; new perspectives on intercalation schemes are in Ratzon 2016.

3 Hunger 1977. On Neo-Babylonian and Achaemenid intercalations see Steele 2007, 137-140.

4 In the 19-year cycle there was an intercalary month in each of the $1^{\text {st }}, 3^{\text {rd }}, 6^{\text {th }}, 9^{\text {th }}, 12^{\text {th }}, 14^{\text {th }}$, and $17^{\text {th }}$ years. With the exception of the $12^{\text {th }}$ year when intercalary Ulülu (i.e., second sixth month) was inserted, an intercalary Addaru (i.e., second twelfth month) was added. In the first three cycles the presence of intercalary Ulūlu is uncertain, but from cycle 419/418-401/400 B.C., this system can be observed. For details see Ossendrijver 2018, 139-140 and 147-149.

5 For examining the relationship between economic sources and intercalation see recently Stratford 2015 (on Old Assyrian evidence). 
BM 31230 is a promissory note written in the form of an $u^{\prime} i l t u .{ }^{6}$ It describes a silver loan of five minas (ca. $2.5 \mathrm{~kg}$ ) that was to be paid back with an interest of $20 \%$. It was the intercalary month along with the clause on interest payment that called my attention to this document. M. Van De Mieroop made noteworthy statements about how intercalary months and interest-bearing loans are related. Van De Mieroop assumed that the irregular insertion of intercalary months in the Mesopotamian calendar is one of the reasons why the interest specified in economic texts cannot be understood as the annual rate of interest, requiring the debtor to pay interest on the basis of the amount of loan and the loan period; instead, the interest was to be added to the loan in one sum. ${ }^{7}$ According to Van De Mieroop, this theory of loan provides a solution for handling anomalies caused by the unexpected insertion of intercalary months in the calendar. By contrast, P. Vargyas had put forth an opposing view drawing on Babylonian sources from the first millennium B.C. ${ }^{8}$ Vargyas proposed that the ancient Babylonians employed a sophisticated formula to calculate interest rates and their advanced mathematical knowledge enabled them to calculate the interest to be paid even when an intercalary month was inserted in the calendar. Van De Mieroop refused to accept Vargyas's proposal. ${ }^{9}$ Therefore, in the present paper I will examine interest-bearing loans written in intercalary months, including the text analyzed here, in an effort to take a side in the debate.

There are sixteen published documents from $1^{\text {st }}$ millennium B.C. Babylonia that deal with interest-bearing loans and were recorded in intercalary months. They date from 653 B.C. to 269 B.C., but the majority of them were written between 621 B.C. and 499 B.C. There are more documents dated to intercalary Addaru (month XII2) than to intercalary Ulūlu (month VI2); this is not an unusual tendency, since there were more intercalary Addaru than intercalary Ulūlu months, and more interest-bearing debt notes were made in the second half of the Babylonian year. ${ }^{10}$ Four loan documents include antichretic pledge (Zinsantichrese). ${ }^{11}$ Two of them solely denote antichretic pledge: a servant is offered to the creditor in one document ${ }^{12}$ and a house in the other ${ }^{13}$ to pay off the equivalent of the entire interest to be paid. A third text documents a loan of a large amount of money: 600 shekels of silver. In this case, the income deriving from the rental of the assigned house covered half of the loan's interest, so only the other half of the loan bore interest. ${ }^{14}$ In the fourth case, the text sets out a deferred interest-bearing loan, the accruing of interest begins two

$6 \quad$ On the Neo-Babylonian u'iltu see in particular Petschow 1956; further Oelsner 2001, 289-305; Jursa 2002, 197-203; Wunsch 2002, 224-230; Oelsner - Wells - Wunsch 2003, 949-961.

7 Van De Mieroop 1995, 360 and 2005, 29.

8 Vargyas 2000, 1102.

9 Van De Mieroop 2005, 361 n. 41.

10 See Csabai 2008, 205-207. A year is not understood in terms of a calendar year but corresponds to the agricultural year (starting at harvest time and ending at the next harvest).

11 In the case of antichretic pledge, the debtor offered a source of regular income to the creditor to substitute interest payments. The most common example of such substitution is the assignment of the right to rent out a house in order to settle interest payment during the interest period.

12 TMH 2/3 115 (549 B.C.).

13 TCL 1221 (605 B.C.).

14 Ellis 1984 no. 1. (653 B.C.) The sum of the loan amounted to ten minas of silver. For five minas the debtor had to pay 5 shekels per mina annually (i.e., an interest rate of 8.33\%). The other five minas of silver were covered by the assignment of a house to the creditor, as antichretic pledge (i.e., its annual rent amounted to 25 shekels). 
months later. ${ }^{15}$ There is also a so-called hubuttu loan ${ }^{16}$ among the sources; however, it is not a loan of silver but that of barley. ${ }^{17}$ Thirteen of the texts document interest-bearing loans, on one tablet the sign recording the rate of interest is broken, ${ }^{18}$ and in another document the interest rate is uncertain. ${ }^{19}$ The following rates of interest occur: $8.33 \%,{ }^{20} 12.5 \%,{ }^{21} 16.66 \%{ }^{22}$ and $20 \% .{ }^{23}$

Despite the limited number of available texts, the beginning of the interest period shows significant variation. There are three deferred interest-bearing loans, one of them was discussed earlier (Jursa 1998 no. 16). In the other two promissory notes, the interest began to run on the first day of the month following the conclusion of the agreement (Dar 556 and partially BM 31230). In the other nine loans, the interest started to run in the intercalary month when the document was written. There is at least one antedated loan in which the initial interest payment was due on the first day of intercalary Addaru, the month when the text was written. ${ }^{24}$ Two tablets expressly required the debtor to pay interest from the very day on which the loan document was drawn up. ${ }^{25}$ Seven cuneiform texts prescribed interest payment in the simplest, most common form, ${ }^{26}$ starting on the date of the debt note.

Interest-bearing loans made in intercalary months do not include any special clause implying that loans written in intercalary months entailed extraordinary legal or administrative conditions to be observed by contracting parties. Legal terms and conditions seem to have been identical in regular and in intercalary months in the Neo-Babylonian and Achaemenid periods. Nonetheless, the fact that eleven of the eighteen loan contracts required the debtor to start accruing interest in the intercalary month means that the intercalary month was included in the interest period.

\section{BM 31230}

The following document (Fig. 1) may facilitate us to take a side in the debate. Previous studies on Neo-Babylonian loans revealed that promissory notes had sometimes been renewed or rewritten, which is also true for the loan recorded in BM 31230. Fortunately, the original promissory note (Dar 170) is also preserved, allowing us to compare the two texts and investigate the differences. A loan was renewed, as a rule, in the case of paying arrears, changes in the conditions, or changes

15 Jursa 1998 no. 16 (269 B.C.). The creditor required three items as security for a loan of a relatively small amount of silver (beside an antichretic pledge both the debtor's wife and son secured the debt).

16 The exact legal and economic meaning of hubuttu (as well as hubuttūtu and hubuttātu) loans is still unclear, see, for instance, Skaist 1994, 52-56; Westbrook 2003b, 403; Slanski 2003, 510; on the Neo-Babylonian material see Petschow 1956, 15 n. 31; Shiff 1988; Oelsner - Wells - Wunsch 2003, 950; and on loans from the Sîn-uballit archive Cseke 2014, 573-574.

17 VS 335 (562 B.C.): 1.1.0.0. (216 litres of) barley, in Ālū Bānītūya.

18 Kessler 1991 no. 88: 1' (603 B.C.).

19 YOS 19 26: 5 (546 B.C.).

20 Ellis 1984 no. 1: 3-4 (653 B.C.) and BE 8/1 157: 4-5 (621 B.C.).

21 OECT 12 A 91: 4-5 (574 B.C.).

22 Hunger 1970 no. 17 III: 26-35 (598 B.C.).

23 Hunger 1970 no. 17 II: 6-20 (600 B.C.); Nbn 438 (546 B.C.); Nbn 678 (543 B.C.); Cyr 219 (532 B.C.); BM 31230 (516 B.C.); Dar 556 (499 B.C.); Jursa 1998 no. 16 (269 B.C.).

24 Nbn 678 was written on the $16^{\text {th }}$ of intercalary Addaru and the interest started to run on the first day of the same intercalary Addaru.

25 Hunger 1970 no. 17 II: 6-20 and III: 26-35.

26 E.g., Nbn 438: 5-7 ša arḩi ina muḩhi 1 manê 1 šiqil kaspi ina muḩhīšu irabbi 'each month one shekel of silver per one mina will accrue against him'. 
in the amount of loan. None of these, however, was the case for this tablet.

BM 31230 belongs to the Egibi archive, the largest, most famous archive in the Neo-Babylonian period. ${ }^{27}$ It concerns the main protagonist of the fourth generation, a certain Marduk-nāșir-apli. ${ }^{28}$ These two documents were not included in the previous edition of the archive. Dar 170 has already been available in autograph and transliteration, ${ }^{29}$ thus only a translation of this text is presented here. In the case of BM 31230, the autograph (Fig. 1), the transliteration and the translation are published in the present study for the first time.

\section{Dar 170}

promissory note for silver

Babylon, Dar. I 16-VI-5 (September 517 B.C.)

\section{Translation}

${ }^{1}$ Five minas of ginnu-silver of $1 / 8$ alloy, which (is used) in trading (lit. 'giving and receiving'), (are) ${ }^{3}$ owed to Marduk-nāșir-apli, son of Itti-Marduk-balāțu, descendant of Egibi by Nabû-apla-iddin, ${ }^{5}$ son of Nabû-ēṭir, descendant of Isinnāya.

Each month one shekel of silver per one mina will accrue against him (i.e., $20 \%$ interest). ${ }^{7}$ Apart from a previous / an earlier debt [owed by?] Nabû-apla-iddin who was present(?).

${ }^{9}$ Witnesses: Arrabu, descendant of Šangû-[...]; [...], descendant of Atû; ${ }^{11}[\ldots$, son of] Marduk-nāșir-apli, [descendant of ...]; Marduk-balāssu-iqubi, ${ }^{13}$ [son of Bān]īya, descendant of Nabaya; [Nergal-ušal]lim?, son of Mušēzib-Marduk, ${ }^{15}$ descendant of Nappāḩu; Nabû-apla-iddin, son of Iddin-Nabû, descendant of Dābibī.

Scribe: Bulțāya, ${ }^{17}$ son of Nabû-apla-iddin, descendant of Isinnāya.

(Written in) Babylon, (on the) $16^{\text {th }}$ day of Ulūlu, the $5^{\text {th }}$ year (of the reign) of ${ }^{19}$ Darius (I), king of Babylon and (of) the lands.

\section{Notes}

(1-2) The expression kaspu ša ginnu was identified by Vargyas as Darius' coined silver siglos. ${ }^{30}$ However, with the exception of Powell, ${ }^{31}$ his theory remains largely unaccepted in the field of the Neo-Babylonian studies. ${ }^{32}$ Instead, M. Jursa's opinion has been followed since then. ${ }^{33}$ The clause kaspu ša ginnu ša nadāni u maḩāri 'ginnû-silver, which (is used) in trading (lit. "giving and receiving”)' has been subject to various investigations. ${ }^{34}$

27 For an overview of the Egibi archive see Wunsch 1999a; 1999b; 2007. For detailed discussions of parts of the archive see Wunsch 2000 and Abraham 2004.

28 The Marduk-nāșir-apli file of the archive was discussed in detail by Abraham (2004).

29 Joannès 2000/2002.

30 Vargyas 2001, 24-34. See in detail Vargyas 1999.

31 Powell 1999, 21-23.

32 For the sigloi, with a review of previous studies, see Corfù 2010.

33 Jursa et al. 2010, 480-485.

34 Vargyas 2001, 21-24 and Jursa et al. 2010, 488-489, respectively. 
(3-5) The creditor, Marduk-nāșir-apli/Itti-Marduk-balāțu//Egibi is the main protagonist in the fourth generation of the Egibis. ${ }^{35}$ The debtor, Nabû-apla-iddin/Nabû-êțir//Isinnāya is otherwise unattested in the published tablets assigned to the archive of Marduk-nāșir-apli.

(6-7) This is one of the most common interest clauses in the Neo-Babylonian records, it stipulates a yearly $20 \%$ rate of interest on a monthly basis.

Witnesses and the scribe: I restore six witnesses in Dar 170.

Nergal-ušallim/Mušēzib-Marduk//Nappāhnu occurs both in Dar 170 and BM 31230. ${ }^{36}$

Bulțāya/Nabû-apla-iddin//Isinnāya was the scribe who wrote both tablets. Presumably, he was the son of the debtor. From the Neo-Babylonian period we know many loan contracts, the scribe of which belonged to the debtor's family ${ }^{37}$ sometimes the scribe was the debtor himself. ${ }^{38}$

\section{BM $31230(=\text { Bertin 2067 })^{39}$}

promissory note for silver

Babylon, Dar. I 4-XII2-5 (March 516 B.C.)

obv. 1) [5] MA.NA KÙ.BABBAR šá gìn-nu šá na-da-nu

2) [u m]a-ḩa-ri šá IdšÚ-PAB-A A-šú šá ${ }^{\mathrm{K}} \mathrm{II}^{\mathrm{d}} \mathrm{A}$ AMAR.UTU-DIN

3) [A ${ }^{\mathrm{I}}$ e-gi-bi ina UGU ${ }^{\mathrm{Id}} \mathrm{NÀ}-\mathrm{A}-\mathrm{MU}$

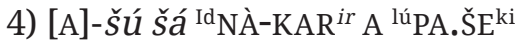

5) ul-tu U $\mathrm{U}_{4}$ 1.KAM šá itišE KI ${ }^{\mathrm{iti}} \mathrm{BÁRA}$

6) šá ITI ina UGU ${ }^{h i} 1$ ma-né-<e> 「1’ [G]ÍN KÙ.BABBAR

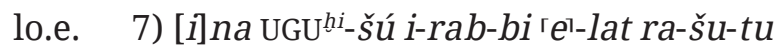

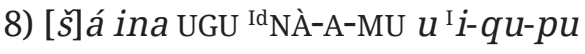

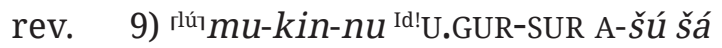

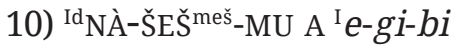

11) IdU.GUR-GI A-šú šá I KAR-d ${ }^{I}$ Š A ${ }^{\text {lúSIMUG }}$

12) lúUMBISAG ${ }^{\mathrm{I}} b u l-t ̣ a-a$ a-šú šá Id NÀ-A-MU

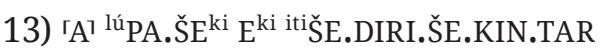

14) ${ }^{\circ} \mathrm{U}_{4} 4$ 1.KAM MU 5.KAM ${ }^{\mathrm{I}}$ da-ri-muš

15) LUGAL $E^{k i} u$ KUR.KUR

35 Abraham 2004, 13-16.

36 Nergal-ušallim(=Šullumu)/Mušēzib-Marduk//Nappāhnu appears as witness at least six more times in the Marduk-nāșir archive: Abraham 2004 no. 85 (BM 41449); no. 97 (= Dar 182); no. 100 (= Dar 213); no. 102 (= Dar 268); no. 110 (= Dar 338); no. 112 (= Dar 345). It is especially interesting that four of these texts were written during the fifth year of Darius I: Dar 170 and BM 31230 which are discussed here, as well as Abraham 2004 no. 85, and no. 97). In all of these four texts he is called Nergal-ušallim. In the other four texts from the $6^{\text {th }}$ (no. 100), $10^{\text {th }}$ (no. 102), $12^{\text {th }}$ (no. 110), and $13^{\text {th }}$ (no. 112) years of Darius I his name appears as Šullumu. Therefore, I suppose that the tablet Abraham 2004 no. 85, which is broken at the date (see Abraham 2004, 364), was written in the $5^{\text {th }}$ year of Darius I, too.

37 Some examples: Nbk 68: the debtor is Nabû-gāmil/Rihētu//Sîn-nāșir, the scribe is Nabû-zēr-ibni/Rihētu// Sîn-nāșir. Nbk 281: the debtor is Nabû-aḩhē-iddin/Nabû-kēšir//Naggāru, the scribe is Bēl-zēr-ibni/Nabûkēšir//Naggāru.

38 VS 4 10: Bēl-uballiț/Mīnu-ana-Bēl-dannu//Nūr-Šamaš is both debtor and scribe. Dillard 1975 FLP 1522 : the debtor and the scribe is Nabû-ēțir-napšāti/Nabû-šum-iškun.

39 The tablet was first autographed by G. Bertin by the end of $19^{\text {th }}$ century, but his work remained unpublished. 


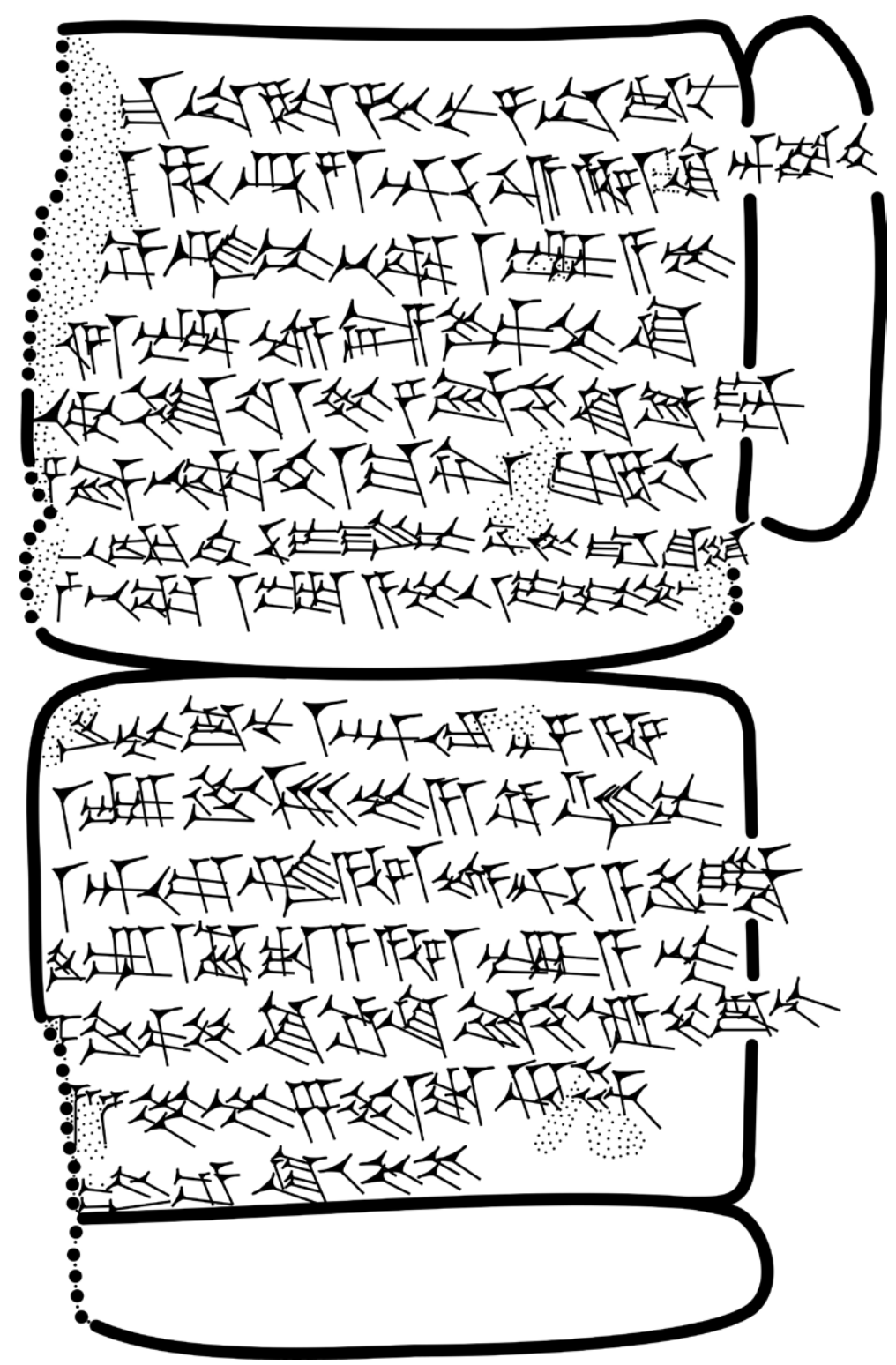

FIGURE 1. BM 31230. ㄷ Zs. J. Földi

\section{Translation}

${ }^{1}$ Five minas of ginnû-silver, which (is used) in trading (lit. 'giving and receiving'), (are) owed to Marduk-nāșir-apli, son of Itti-Marduk-balāțu, ${ }^{3}$ descendant of Egibi by Nabû-apla-iddin, son of Nabû-ētir, descendant of Isinnāya.

${ }^{5}$ From the $1^{\text {st }}$ day of Addaru and! (text: 'with') Nisannu each month one shekel of silver per one mina (i.e., 20\% interest) ${ }^{7}$ will accrue against him. (This is) apart from (another) debt which (is) owed by Nabû-apla-iddin and Iqūpu.

${ }^{9}$ Witnesses: Nergal-ēțir, son of Nabû-ahhēe-iddin, descendant of Egibi; ${ }^{11}$ Nergal-ušallim, son of Mušēzib-Marduk, descendant of Nappāhnu.

Scribe: Bulțāya, son of Nabû-apla-iddin, ${ }^{13}$ descendant of Isinnāya.

(Written in) Babylon, (on the) $4^{\text {th }}$ day of intercalary Addaru, the $5^{\text {th }}$ year (of the reign) of Darius (I), ${ }^{15} \mathrm{king}$ of Babylon and (of) the lands. 


\section{Notes}

(1-2) Since there is little room on the tablet before the signs MA.NA, I expect only one sign, which must be a figure. Less than seven months passed since the date of Dar 170, thus I do not suppose that the sum of the loan became lower. However, it cannot be one mina more either, because of the rate of interest 20\%. (On account of the months that passed, at least 30 shekels of silver could be added to the five minas, which would result in more signs). Therefore, the sum of the loan is restored from Dar 170 line 1.

The second contract (BM 31230) was a renewed agreement, the sum of the loan was handed over for seven months. I think this is the reason why the scribe omitted the explicit fineness of silver (875\% with Dar 170, line 1: kaspu ša ina 1 šiqil bitqa "silver of 1/8 alloy"). As the standard fineness of ginnû-silver was $875 \% 0,{ }^{40}$ it was sufficient to name the main characteristics of the silver.

(3-4) Apart from Dar 170 and BM 31230, the debtor Nabû-apla-iddin/Nabû-ētiir//Isinnāya is not known to have had any previous connection with the Marduk-nāṣir-apli archive. ${ }^{41}$

(5-7) This is an extended interest clause and it consists of two elements. The first element in line 5 stipulated the accurate day, from which on the interest had to be accrued, or paid. It seems that the beginning of the interest period of a loan did not ensue in many cases from the date of the text. According to the variants of this clause, the interest could accrue 1) from the same day as the date of the loan contract, 2) from the first day following the date of the loan contract, 3) from the first day of one of the months following the month in the date of the loan contract ${ }^{42} 4$ ) or in some cases it began antedated, i.e. before the date of the loan contract. ${ }^{43}$ However, the formulation attested in BM 31230 line 5, naming two months, is previously unattested and so far unique in the Neo-Babylonian written material. The second element in lines 6-7 was the common interest clause, which is identical with Dar 170 lines 5-7.

(7-8) Since the debtor in Dar 170 was only Nabû-apla-iddin/Nabû-êtir//Isinnāya, and the debt note, which BM 31230 in the elat-clause in lines 7-8 refers to had two debtors, namely Nabû-apla-iddin and Iqūpu, these lines cannot refer to Dar 170, but another loan contract. Presumably to the same loan as the one mentioned in Dar 170 lines 7-8.

(9-11) One of the two witnesses, Nergal-ušallim/Mušēzib-Marduk//Nappāhnu appeared in the first loan as well.

BM 31230 is a renewal of the original Dar 170 loan made almost seven months earlier. There is no change in the contracting parties, nor any new clause added to the document, and the sequence of clauses remained unchanged as well. The two texts only differ in the following points: the second text explains silver fineness in a briefer manner, while the clause on the interest rate is explained in more detail, and there is a second debtor identified in the elat-clause. Despite these slight changes, the agreement remained fundamentally the same. The creditor and the debtor were the same individuals as before, the amount of the loan was probably the same, the interest imposed on the loan was the same, and both texts made a reference to another loan. Therefore, the question arises as to why the original loan was rewritten. The answer must lie in the slight differences mentioned above. The shorter description of silver fineness actually referred to the same type of silver, so this explanation can be ruled out. The new person specified in the elatclause is not included as a party in either text. Consequently, the only reason why the loan was

40 Vargyas 2001, 24; Jursa et al. 2010, 481.

41 See Abraham 2004.

42 The interest could accrue deferred from the first, second, third etc., until the eleventh month after the date of the conclusion of agreement, see Csabai 2018, 19.

43 Csabai 2018. 
rewritten must have been the modified and expanded clause of interest. In line 5 the text reveals that the loan bore a $20 \%$ yearly interest rate, starting on the first day of month Addaru and Nisannu. This is an otherwise unprecedented case among the Neo-Babylonian and Achaemenid interest-bearing loans. Normally, the interest period began on the first day of a certain month, and save tablet BM 31230, there are no other sources specifying two months with regard to the starting point of the interest period. Furthermore, these were two consecutive months being the last and the first month of the Babylonian year. This brings up the question why both months were mentioned in the clause if they were consecutive ones, and if the interest started to run in Addaru and the same conditions applied for the following month as well which was Nisannu. This phenomenon could be explained by the use of different interest rates for the two consecutive months. However, this possibility can be ruled out because there is only one and the same rate of interest set out in both documents. Since the interest ran in both months, and the loan bore the same interest in both months, it should have been sufficient to set out only one month in the clause - but it was not the case. The reason for specifying two months in the interest clause is thus still unclear.

The examination of the date of BM 31230 may clarify the issue. The tablet was written in intercalary Addaru. There are texts from the first millennium B.C. showing that an intercalary month could be inserted in the calendar not only after, but before the regular Addaru month, too. ${ }^{44} \mathrm{How}$ ever, this seems to have been the case only in the Neo-Babylonian period. According to Ossendrijver, there was no intercalary Addaru preceding the regular Addaru in the Achaemenid period. ${ }^{45}$ This rules out the possibility that the intercalary Addaru in BM 31230 preceded the regular Addaru month.

The loan was renewed after almost seven months with the same terms and conditions, including the same interest rate of $20 \%$, annually. The conditions were the same, therefore the renewal of the debt note must have been motivated by the insertion of an intercalary month. The interest did not start to run on the date of BM 31230, nor on the first day of the intercalary month (i.e. antedated), ${ }^{46}$ nor on any other day of the intercalary month. Rather, it started to run on the first day of the preceding month Addaru and again started to run on the first day of the following month Nisannu, both with the same interest rate of $20 \%$ as it was also specified in the original promissory note. Therefore, we may come to the conclusion that the debtor was not required to pay interest for intercalary Addaru. ${ }^{47}$

If the interest was to be paid for the intercalary month, (a) it should have started to run on the first day of preceding Addaru, but Nisannu should not have been named, or (b) it should have started to run on the first day of the intercalary Addaru or (c) on the very date of BM 31230, but in this case the other two months need not have been specified. Consequently, this raises the question why the agreement did not simply stipulate that interest was to be paid from the first day of Nisannu. In my opinion, it is no accident that two months were included in the clause. The reason for this is that the new contract was not a mere renewal but rather the modification of the original. In case of a renewal, the conditions of the first loan became invalid and were replaced

44 See San Nicolò 1933. His sources were supplemented by Kleber 2008, 267 and n. 752; but cf. most recently Ossendrijver 2018.

45 As it was pointed out by Ossendrijver 2018, 138-139. However, Ossendrijver's scrupulous study is concerned with the last years of Darius I and with the reigns of the following Achaemenid rulers. He proposes that 19-year cycles can be observed from the $10^{\text {th }}$ year of Xerxes on (but the use of intercalary Ulūlu was not regular). Since Britton's (2002, 30-36) findings showed the irregular use of the 19-year cycle during the reign of Cyrus and Cambyses, based on Ossendrijver's and Britton's findings, I believe that BM 31230 was written in intercalary Addaru following the regular Addaru.

$46 \quad$ Csabai 2018

47 In line 5, an alternative translation 'from the $1^{\text {st }}$ day of Addaru with Nisannu', would result in the same meaning. 
by new ones. However, the conditions of the old agreement remained effective until the date of its renewal. Dar 170 stipulated an interest rate of $20 \%$ for a silver loan of five minas that had to be paid monthly during the interest period. The new agreement was made on the fourth day of the intercalary month; therefore, the above interest should generally have been expected to be accrued in that month as well.

Furthermore, there is another significant feature of BM 31230. It was written on the fourth day of the month which is at the beginning of the month. This suggests that the interest of the loan started to run at the beginning of the month, so the new debt note had to be concluded before the monthly interest was added to the debt. The debtor would avoid this interest payment. I wish to address another issue with regard to the loan by examining the economic reasons that led to the modification of the original agreement. The modification of the original note was motivated by the enormous amount of the loan which was 300 shekels. This amount is the equivalent of the total annual wage of about five to ten people in the age of Darius $\mathrm{I}^{48}$ The amount of the loan's monthly interest is also a large sum: five shekels. This was the pressing reason why the debtor (and the scribe who was the debtor's son) requested the modification of the agreement when they became aware of the insertion of the intercalary month.

However, only a mutual agreement could lead to this situation between the creditor(s) and debtor(s). Strictly speaking, the permission of the creditor(s) was mandatory. The result of a successful deal can be observed in BM 31230.

The effort to avoid an extra interest payment due to the insertion of an intercalary month, as represented by BM 31230, is not a unique case in the Neo-Babylonian period. If I am correct there is at least one more occasion of the phenomenon. We know another example from the reign of Nebuchadnezzar II, although in this case the loan was not written in the intercalary month itself. B. Funck published and commented on three promissory notes that are of interest here. ${ }^{49}$ They represent a debt note bearing a $20 \%$ rate of interest, recorded in the $3^{\text {rd }}, 4^{\text {th }}$ and $7^{\text {th }}$ years of Nebuchadnezzar II. ${ }^{50}$ Among these years, there was an intercalary Ulūlu in the $7^{\text {th }}$ year of Nebuchadnezzar II. The first promissory note ${ }^{51}$ about 15 shekels of silver was written on the $15^{\text {th }}$ of Addaru (month XII), and the loan bore a $20 \%$ of interest starting to run on the $20^{\text {th }}$ of the same month..$^{52}$ The second record, Nbk 39 was written again in Addaru on an uncertain day of the month, and the $20 \%$ of interest was accrued from an uncertain day of the same month. ${ }^{53}$ The loan was renewed in the $7^{\text {th }}$ year of Nebuchadnezzar II. The conditions of the new agreement ${ }^{54}$ did not change, the sum remained 15 shekels of silver, and it bore a 20\% interest. However, in this case the text was not written in Addaru, but in Ulūlu (month VI), ${ }^{55}$ and the $20 \%$ interest did not start to run on a day of the same month as it was the case in the two preceding loans, but from the month of Tašritu

48 On Neo-Babylonian and Achaemenid wages see Jursa et al. 2010, 669-728; most recently Jursa 2015, with references. For the value of the Babylonian wages in relation of the standard of living see Pirngruber 2016.

49 Nbk 34 (= Liv 5); Nbk 39 and Nbk 60 (= Liv 141). See Funck 1982, 51-52.

50 The creditor was Kudurru/Iqī̄̌āya, the debtor was Mukīn-zēri/Pir'u in Nbk 34. In Nbk 39 there were two debtors, Kīnāya(=Mukīn-zēri)/Pir'u and his wife Bu'iti, and the latter appears alone in the third text Nbk 60 . After Funck $(1982,52)$ the main reason of the two novations was the change of the debtors.

$51 \quad$ Nbk 34.

52 Nbk 34: lines 3-6 and 13.

53 The exact day is broken in the clause of the interest, as well as in the date, but in both cases the name of the month is preserved.

54 Nbk 60.

55 Nbk 60: lines 13-14. 
(month VII) onwards. ${ }^{56}$ However, this month was not the following month, but the second one following the conclusion of the agreement, because of the insertion of an intercalary Ulülu (month VI2). Again, to avoid the payment of interest for the intercalary month might be the reason why the agreement was renewed in Ulūlu. The interest for the regular Ulūlu was still valid in line with the previous debt agreement. The main clauses of the previous debt agreement(s) remained unchanged in the terms and conditions of the new agreement, but the fact, that according to the conditions of the new contract, the payment of the interests falls on the month of Tašritu can lead to the conclusion, that the creditor permitted the debtor not to pay interest during the intercalary month Ulūlu between the month of the contract and Tašrītu. Since the loan was renewed on the occasion of the insertion of an intercalary month, the changes in the parties were realized, as well. ${ }^{57}$

The renewal in the regular Ulūlu just before the intercalary month can underline the theory of Földi on the occupation- and vacancy-clauses of Old Babylonian house rental contracts, that intercalary months were at least sometimes anticipated by the ancient Babylonians, i.e. already in the month preceding the intercalary month. ${ }^{58}$

In conclusion, the cuneiform texts investigated here can not verify on the whole either of the two concepts mentioned. The above findings shed light on how interest payments were construed with regard to intercalary months in the Neo-Babylonian period. In years with intercalation debtors were required to pay interest for thirteen months, which was calculated not by changing the calculation of paying $1 / 12$ of interest monthly to paying retroactively $1 / 13$ of it, ${ }^{59}$ but by paying 13/12 of the interest. This statement is corroborated by other promissory notes made in any intercalary month, as none of the documents stipulated the exclusion or the extraordinary status of an intercalary month. This point is further proven by BM 31230 and probably by Nbk 60 that was only concluded to avoid the payment of an additional monthly interest. The effort to avoid an additional interest portion shows that otherwise an extra (a thirteenth 1/12) interest was accrued on the debt in the intercalary month of an intercalary year.

\section{Acknowledgments}

I gratefully acknowledge the permission of the Trustees of the British Museum to study and publish BM 31230. I wish to express my special thanks to Cornelia Wunsch and Enrique Jiménez who kindly provided me with excellent photographs of the tablet. I am deeply indebted to Zsombor Földi, who prepared the autograph of BM 31230, and made many helpful suggestions on an earlier draft of my paper. This research was funded by the European Union and the Hungarian State, co-financed by the European Social Fund in the framework of TÁMOP-4.2.4.A/2-11-1-2012-0001 Program. A shorter version of this paper was recently published in Hungarian. ${ }^{60}$

\section{References cited}

Abraham, K. 2004: Business and Politics under the Persian Empire. The Financial Dealings of Marduk-nāṣir-apli of the House of Egibi (521-487 B.C.E.). Bethesda.

\footnotetext{
56 Nbk 60: lines 3-5.

57 As Funck 1982, 52 suggested.

58 See Földi 2009, 19 and 22. Unfortunately, a similar clause is not known among the Neo-Babylonian house rental contracts, see most recently Zawadzki 2018, especially 57-58.

59 This method really would perturb the usual payment terms.

60 Csabai 2019
} 
BE 8/1: Clay, A. T. 1908: Legal and Commercial Transactions, Dated in the Assyrian, Neo-Babylonian and Persian Periods, Chiefly from Nippur. (The Babylonian Expedition of the University of Pennsylvania 8/1) Philadelphia.

Britton, J. P. 2002: Predictions of Lunar Phenomena in Babylonian Astronomy. In: StEELE, J. M. - IMHAUSEN, A. (eds.): Under One Sky: Astronomy and Mathematics in the Ancient Near East. (Alter Orient und Altes Testament 297) Münster, 5-20.

CoRfù, N. A. 2010: Die sogenannten achaimenidischen Bogenschützenmünzen - Die Herkunft von Dareikoi und Sigloi. Archäologische Mitteilungen aus Iran und Turan 42, 165-206.

CsabaI, Z. 2008: Verbrauchsdarlehen in Babylonien im 1. Jtsd. v. Chr. Eine Vorstudie. In: Vargyas, P. - SzABó, Á. (eds.): Cultus Deorum Studia Religionum ad Historiam. Vol. I. De Oriente Antiquo et Regione Danuvii Praehistorica in Memoriam István Tóth. (Ókortudományi Dolgozatok 1) Pécs, 203-218.

CsabaI, Z. 2018: Antedated Paying of Interest in the Neo-Babylonian and Achaemenid Periods. In: GRÜLL, T. (ed.): Mobility and Transfer. Studies on Ancient Economy. (Ancient Near Eastern and Mediterranean Studies 3) Pécs - Budapest, 17-34.

CsABAI, Z. 2019: Babilóniai kölcsönök kezelése szökőhónapokban [Babylonian Loans in Intercalary Months]. Pontes 2, 11-30.

CSEKe, H. 2014: The Economic Determination of the Changing Interests. A Survey Based on the Loan Documents of the Neo-Babylonian Sîn-uballit Archive. In: CsABAI, Z. (ed.): Studies in Economic and Social History of the Ancient Near East in Memory of Péter Vargyas. (Ancient Near Eastern and Mediterranean Studies 2) Pécs - Budapest, 557-578.

Cyr: Strassmaier, J. N. 1890: Inschriften von Cyrus, König von Babylon (538-529 v. Chr.). (Babylonische Texte 7) Leipzig.

Dar: Strassmaier, J. N. 1897: Inschriften von Darius, König von Babylon (521-486 v. Chr.). (Babylonische Texte 10-12) Leipzig.

Dillard, R. B. 1975: Neo-Babylonian Texts from the John Frederick Lewis Collection of the Free Library of Philadelphia. PhD dissertation (Dropsie University). [MS].

ElLIs, M. DE J. 1984: Neo-Babylonian Texts in the Yale Babylonian Collection. Journal of Cuneiform Studies 36, 1-63. https://doi.org/10.2307/1360010

FöldI, Zs. J. 2009: Rībatum. The Archive of a Priestess from Old Babylonian Sippar / Rībatum. Egy papnó archívuma az óbabilóni Szipparból. BA thesis (ELTE Budapest) [MS].

Funck, B. 1982: Studien zur sozialökonomischen Situation Babyloniens im 7. und 6. Jahrhundert v. u. Z. In: KLENGEL, H. (ed.): Gesellschaft und Kultur im alten Vorderasien. (Schriften zur Geschichte und Kultur des Alten Orients 15) Berlin, 47-67.

Hunger, H. 1970: Das Archiv des Nabû-ušallim. Baghdader Mitteilungen 5, 193-204.

Hunger, H. 1977: Kalender. In: EdzArd, D. O. (ed.): Reallexikon der Assyriologie und Vorderasiatischen Archäologie, Band 5. Berlin - New York, 297-303.

Hunger, H. - Pingree, D. 1999: Astral Sciences in Mesopotamia. (Handbuch der Orientalistik I, 44) Leiden Boston - Köln. https://doi.org/10.1163/9789004294134

JoAnNÈs, F. 2000/2002 (online): Strassmaier, Darius 170 . http://www.achemenet.com/fr/ item/?/sources-textuelles/textes-par-langues-et-ecritures/babylonien/archives-egibi/1655924 (last accessed: $17^{\text {th }}$ of October 2019).

JuRsa, M. 1998: Der Tempelzehnt in Babylonien vom siebenten bis zum dritten Jahrhundert v. Chr. (Alter Orient und Altes Testament 254) Münster.

JuRSA, M. 2002: Debt and Indebtedness in the Neo-Babylonian Period: Evidence from the Institutional Archives. In: Hudson, M. - Van De Mieroop, M. (eds.): Debt and Economic Renewal in the Ancient Near East. (The International Scholars Conference on Ancient Near Eastern Economies 3) Bethesda, 197-219.

JurSA, M. ET AL. 2010: Aspects of the Economic History of Babylonia in the First Millennium B.C. Economic Geography, Economic Mentalities, Agriculture, the Use of Money and the Problem of Economic Growth. (Alter Orient und Altes Testament 377 = Veröffentlichungen zur Wirtschaftsgeschichte Babyloniens im 1. Jahrtausend v. Chr. 4) Münster.

Jursa, M. 2015: Labor in Babylonia in the First Millennium BC. In: Steinkeller, P. - Hudson, M. (eds.): Labor 
in the Ancient World. (The International Scholars Conference on Ancient Near Eastern Economies 5) Dresden, 345-396.

Kessler, K. 1991: Uruk. Urkunden aus Privathäusern. Die Wohnhäuser westlich des Eanna-Tempelbereichs, Teil I. Die Archive der Söhne des Bēl-ušallim, des Nabû-ušallim und des Bēl-supê-muhur. (Ausgrabungen in Uruk-Warka, Endberichte 8) Mainz am Rhein.

KLeBER, K. 2008: Tempel und Palast. Die Beziehungen zwischen dem König und dem Eanna-Tempel im spätbabylonischen Uruk. (Alter Orient und Altes Testament 358) Münster.

Liv: Strassmaier, J. N. 1885: Die babylonischen Inschriften im Museum zu Liverpool nebst andern aus der Zeit von Nebukadnezzar bis Darius. Leiden.

NbK: Strassmaier, J. N. 1889: Inschriften von Nabochodonosor, König von Babylon 604-561 v. Chr. (Babylonische Texte 5-6) Leipzig.

Nbn: Strassmaier, J. N. 1889: Inschriften von Nabonidus, König von Babylon 555-538 v. Chr. (Babylonische Texte 1-4) Leipzig.

OECT 12: JoAnNÈs, F. 1990: Les tablettes néo-babyloniennes de la Bodleian Library conservées à l'Ashmolean Museum. (Neo-Babylonian Tablets in the Asmolean Museum). (Oxford Editions of Cuneiform Texts 12) Oxford.

Oelsner, J. 2001: Neo-Babylonian Period. In: Westbrook, R. - Jasnow, R. (eds.): Security for Debt in Ancient Near Eastern Law. (Culture and History of the Ancient Near East 9) Leiden - Boston - Köln, 289-305.

Oelsner, J. - Wells, B. - Wunsch, C. 2003: Neo-Babylonian Period. In: Westbrook 2003a, 911-974. https://doi. org/10.1163/9789047402091_027

Ossendrijver, M. 2018: Babylonian Scholarship and the Calendar during the Reign of Xerxes. In: WAERzEGgers, C. - SeIre, M. (eds.): Xerxes and Babylonia. The Cuneiform Evidence. (Orientalia Lovaniensia Analecta 277) Leuven, 135-163.

Petschow, H. 1956: Neubabylonisches Pfandrecht. Berlin.

Pirngruber, R. 2016: The Value of Silver: Wages as Guides to the Standard of Living in First Millennium BC Babylonia. In: Kleber, K. - Pirngruber, R. (eds.): Silver, Money and Credit. A Tribute to Robertus J. van der Spek on the Occasion of His $65^{\text {th }}$ Birthday. (Publications de l'Institut historique et archéologique néerlandais de Stamboul 128) Leiden, 107-118.

Powell, M. A. 1999: Wir müssen unsere Nische nützen: Monies, Motives, and Methods in Babylonian Economics. In: Dercksen, J. G. (ed.): Trade and Finance in Ancient Mesopotamia. (MOS Studies 2 = Publications de l'Institut historique et archéologique néerlandais de Stamboul 84) Leiden, 5-24.

Ratzon, E. 2016: Early Mesopotamian Intercalation Schemes and the Sidereal Month. Mediterranean Archaeology and Archaeometry 16, 143-151.

SAN Nicolò, M. 1933: Parerga Babyloniaca X-XI. Archiv Orientální 5, 284-302.

SHIfF, L. B. 1988: Neo-Babylonian “Interest-Free” Promissory Notes. Journal of Cuneiform Studies 40, 187194. https://doi.org/10.2307/1359661

SkAIst, A. 1994: The Old Babylonian Loan Contract. Its History and Geography. (Bar-Ilan Studies in Near Eastern Languages and Culture) Ramat Gan.

Slanski, K. 2003: Middle Babylonian Period. In: Westbrook 2003a, 485-520. https://doi. org/10.1163/9789047402091_012

SteEle, J. M. 2007: The Length of the Month in Mesopotamian Calendars of the First Millennium B.C. In: Steele, J. M. (ed.): Calendars and Years: Astronomy and Time in the Ancient Near East. Oxford, 133-148.

STEELE, J. M. 2011: Making Sense of Time: Observational and Theoretical Calendars. In: RADNER, K. - RoBSON, E. (eds.): The Oxford Handbook of Cuneiform Culture. (Oxford Handbooks in Classics and Ancient History) Oxford, 470-485. https://doi.org/10.1093/oxfordhb/9780199557301.013.0022

Stratford, E. 2015: Successor Eponyms, Debt Notes, Intercalation, and the Old Assyrian Calendar during Kültepe Level II: A Critical Reappraisal. Journal of Near Eastern Studies 74, 301-324. https://doi. org/10.1086/682062

TCL 12: Contenau, G. 1927: Contrats néo-babyloniens I. de Téglath-phalasar III à Nabonide. (Textes Cunéiformes, Musée du Louvre 12) Paris. 
TMH 2/3: KRÜCKMANN, O. 1933: Neubabylonische Rechts- und Verwaltungstexte. (Texte und Materialien der Frau Professor Hilprecht Collection of Babylonian Antiquities im Eigentum der Universität Jena 2/3) Leipzig.

VAn De Mieroop, M. 1995: Old Babylonian interest rates: Were they annual? In: VAn Lerberghe, K. - Schoors, A. (eds.): Immigration und Emigration within the Ancient Near East. Festschrift E. Lipiński. (Orientalia Lovaniensia Analecta 65) Leuven, 357-364.

VAn De Mieroop, M. 2005: The Invention of Interest: Sumerian Loans. In: Goetzmann, W. N. - Rouwenhorst, K. G. (eds.): The Origins of Value. The Financial Innovations that Created Modern Capital Markets. Oxford, 17-30; 359-361.

VARgYAs, P. 1999: Kaspu ginnu and the Monetary Reform of Darius I. Zeitschrift für Assyriologie und vorderasiatische Archäologie 89, 247-268. https://doi.org/10.1515/zava.1999.89.2.247

VARgYaS, P. 2000: Babylonian Interest Rates: Weren’t They Annual? In: Graziani, S. (ed.): Studi sul Vicino Oriente antico dedicati alla memoria di Luigi Cagni. (Istituto Universitario Orientale, Dipartimento di Studi Asiatici, Series Minor 61) Napoli, 1095-1105.

VARgYAs, P. 2001: A History of Babylonian Prices in the First Millennium B.C. Vol. I. Prices of the Basic Products. (Heidelberger Studien zum Alten Orient 10) Heidelberg.

VS 3: Ungnad, A. 1907: Vorderasiatische Schriftdenkmäler der königlichen Museen zu Berlin. Heft 3. Leipzig.

VS 4: UnGnad, A. 1907: Vorderasiatische Schriftdenkmäler der königlichen Museen zu Berlin. Heft 4. Leipzig.

Westbrook, R. (ed.) 2003a: A History of Ancient Near Eastern Law (Handbuch der Orientalistik I, 72/1-2) Leiden - Boston. https://doi.org/10.1163/9789047402091_002

Westbrook, R. 2003b: Old Babylonian Period. In: Westbrook 2003a, 361-430. https://doi. org/10.1163/9789047402091_010

Wunsch, C. 1999a: Handel und Wandel in Babylon: Die Geschäfte der Familie Egibi. In: SEIPEL, W. ET AL. (eds.): Von Babylon bis Jerusalem. Die Welt der orientalischen Königsstädte II. Milano, 325-333.

Wunsch, C. 1999b: Neubabylonische Urkunden: Die Geschäftsurkunden der Familie Egibi. In: RENGER, J. (ed.): Babylon: Focus mesopotamischer Geschichte, Wiege früher Gelehrsamkeit, Mythos in der Moderne. (Colloquien der Deutschen Orientgesellschaft 2) Saarbrücken, 343-364.

Wunsch, C. 2000: Das Egibi-Archiv. I. Die Felder und Gärten (Cuneiform Monographs 20 A-B) Groningen.

Wunsch, C. 2002: Debt, Interest, Pledge and Forfeiture in the Neo-Babylonian and Early Achaemenid Period: The Evidence from Private Archives. In: Hudson, M. - VAn De Mieroop, M. (eds.): Debt and Economic Renewal in the Ancient Near East. (The International Scholars Conference on Ancient Near Eastern Economies 3) Bethesda, 221-255.

Wunsch, C. 2007: The Egibi family. In: LeIck, G. (ed.): The Babylonian World. London - New York, $236-247$.

YOS 19: BEAUlieu, P-A. 2000: Legal and Administrative Texts from the Reign of Nabonidus. (Yale Oriental Studies, Babylonian Texts 19) New Haven - London.

ZaWAdZKI, S. 2018: The Rental of Houses in the Neo-Babylonian Period (VI-V. Centuries BC). Warsaw. 



\section{Hungarian Assyriological Review Author Guidelines}

Manuscripts should be submitted electronically to info@harjournal.com, both in Microsoft Word (doc, docx, rtf) and pdf format. We accept manuscripts in English and German. Non-native speakers must have their text vetted by a native speaker before submission. The manuscript should include the title, the author's name, affiliation and e-mail address, text with footnotes, list of works cited, figure captions, 3-5 keywords, and an abstract in English (100-200 words). It should be typed single-spaced in 12-point Times New Roman or Semiramis font without any additional formatting, e.g. paragraph indenting, page breaks, page numbering, etc. Any special fonts used for characters that cannot be produced with the above fonts must be submitted electronically together with the manuscript. Abbreviations of text editions should follow the system of the RlA. Tables, plates, and figures should not be embedded in the text, but submitted as separate files.

\section{Notes}

$H A R$ does not use in-text citation. Notes (including the references) should be formatted as footnotes, not as endnotes. References in footnotes should consist of the author's last name, the year of publication, and the relevant inclusive pages, figures, plates, etc. Do not use abbreviations such as op. cit., loc. cit., ibid, idem, passim, infra, supra or vague page ranges (e.g., 125f. or 125ff.). Since page numbers are rarely available in the case of online publications, use any available structuring element (e.g., §16, s.v., etc.), if applicable.

\section{References}

${ }^{1}$ Radner 2013, 443. (Single work cited)

${ }^{2}$ Radner 2013, 445-447, fig. 22.1-22.2; Fales 2001. (Multiple works cited, separated by semicolons)

${ }^{3}$ Radner 2008; 2009a, 181, 190; 2009b. (Multiple references to the same author, separated by semicolons. Use alphabetical suffixes for publications by the same author in one year such as 2009a, 2009b, etc.)

${ }^{4}$ Radner - van Koppen 2009, 95-101.

${ }^{5}$ Radner et al. 2014, 141-145, 147-151. (In the case of three or more authors, use et al.)

\section{Footnotes with discussion and references}

${ }^{1}$ The text has been dated by Lambert $(1965,2)$ to the reign of Nebuchadnezzar II, but von Soden $(1985,136)$ argues for a later date.

${ }^{2}$ Numerous tablets from these archives are housed in various American collections (Grant 1918, 199-204; 1919, 1-3; Faust 1941, 3-4) and in European ones (Figulla 1914, III-VI).

\section{Bibliography}

The manuscripts should close with a list of works cited, in alphabetical order by the last name of the first author according to the conventions of the manuscript's language. If the name's initial letter does not exist in the alphabet of the manuscript's language, the name should be placed after the end of the base letter (e.g. Çoşkun should stand after names starting with C). Authors' and editors' first names should be given as initials adapted to the orthography (i.e. "Th.” for Thomas, etc.). Name suffixes such as "Jr.", "IV" should be omitted. Unlike in the references, all authors of an article should be listed. Titles of journals and series should not be abbreviated, but given in 
full. Collective works with more than three articles cited should be included in the bibliography as individual titles. Do not give dates of reprints, but rather supply the original date of publication. Edition information should appear in upper index preceding the year (e.g. ${ }^{2} 2007$ ), editions without numbering ("Revised Edition", etc.) should be supplied after the title. If the real year of publication is significantly different from the official year of publication, you may wish to add the real year in square brackets, e.g. "(2013) [2015]”. Volume information should consist only of the number of the volume (without any abbreviations as "Vol. 2."). In the case of online publications without a recognizable date, use “(online)" instead of the year and place it after the author's publications with a known date. Please ensure that all references listed in the bibliography are cited in the text and that all cited works are included in the bibliography. The manuscript will be returned to the author if significant reformatting of the references is required. Samples:

\section{Books:}

CoHen, M. E. 1993: The Cultic Calendars of the Ancient Near East. Bethesda.

Scurlock, J. - Andersen, B. R. 2005: Diagnoses in Assyrian and Babylonian Medicine. Ancient Sources, Translations, and Modern Medical Analyses. Urbana - Chicago.

Nissen, H. J. - DAmerow, P. - Englund, R. K. 1990: Frühe Schrift und Techniken der Wirtschaftsverwaltung im alten Vorderen Orient. Informationsspeicherung und -verarbeitung vor 5000 Jahren. Berlin.

\section{Edited books:}

Álvarez-Mon, J. - Garrison, M. B. (eds.) 2011: Elam and Persia. Winona Lake.

\section{Book in a series:}

SAllaberger, W. 1999: „Wenn Du mein Bruder bist, ...“ Interaktion und Textgestaltung in altbabylonischen Alltagsbriefen. (Cuneiform Monographs 16) Groningen.

\section{Book chapter:}

Stol, M. 2002: Personen um den König in altbabylonischer Zeit. In: LoRETZ, O. - Metzler, K. A. - Schaudig, H. (eds.): Ex Mesopotamia et Syria Lux. Festschrift für Manfried Dietrich zu seinem 65. Geburtstag. (Alter Orient und Altes Testament 281) Münster, 735-758.

\section{Journal article:}

STEINKELlen, P. 1988: The Date of Gudea and His Dynasty. Journal of Cuneiform Studies 40, 47-53.

\section{Journal without volume number:}

Charpin, D. 2005: Samsu-ditana était bien le fils d’Ammi-șaduqa. Nouvelles Assyriologiques Brèves et Utilitaires 2005, 37-38 (No. 36).

\section{Entry in an encyclopaedia or lexicon:}

Aro, S. 2012: Tabal. Reallexikon der Assyriologie und Vorderasiatischen Archäologie 13, 388-391.

\section{Review:}

Poetto, M. 2014: Review of G. Bunnens, A New Luwian Stele and the Cult of the Storm-God at Til Barsib-Masuwari. Bibliotheca Orientalis 71, 793-797.

\section{Online publications:}

YAkubovich, I. (online): Annotated Corpus of Luwian Texts. http://web-corpora.net/LuwianCorpus/search/ (accessed: 12 May, 2019). 


\section{Figures}

References to figures in the text must appear in consecutive order. Please refer to all types of illustrations (images, drawings, maps, tables, plates, etc.) as Fig. in abbreviated form. A list of figures with appropriate captions and credits should be provided at the end of the manuscript. All explanatory material and legends should be placed in captions. Captions should be set as suggested below, with credits placed in parentheses and ending with a period.

Fig. 1. Aerial view of the excavation area (Photo: R. Matthews).

Fig. 2. Details of the inscription (Durand 2005, 7).

It is the author's responsibility to obtain written permission for reproducing copyrighted images. While there is no limit to the number of figures, their number should be proportional to the length of the text. We accept digital images in colour or grayscale: tiff format of at least $300 \mathrm{dpi}$ resolution is recommended. We accept charts in separate, editable formats only and not as tiff or jpeg files. The file name of any digital image and chart should consist of the author's last name and the figure number (e.g. Kramer_Fig1.tiff). Consider the page size of HAR which is A4 (210×297 $\mathrm{mm}$ ) when sizing your images.

In case of any questions, contact the editors at info@harjournal.com. 


